I N T ER N ATIONAL MONETARY FUND

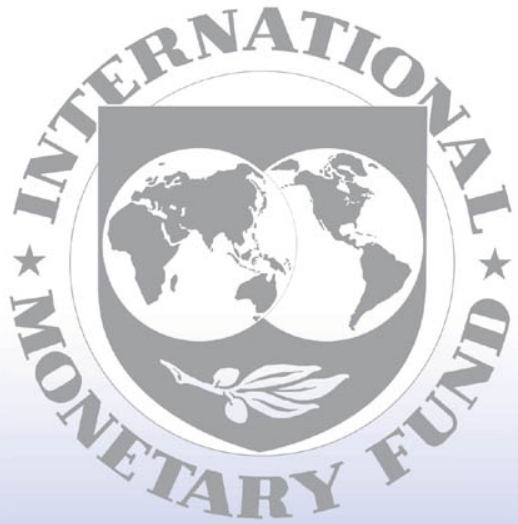

Staff

Country

Reports 


\title{
Sudan: Staff Report for the 2005 Article IV Consultation, Final Review of the 2004 Staff-Monitored Program, and the 2005 Staff-Monitored Program; Public Information Notice on the Executive Board Discussion; and Statement by the Executive Director for Sudan
}

Under Article IV of the IMF's Articles of Agreement, the IMF holds bilateral discussions with members, usually every year. In the context of a combined discussion of the 2005 Article IV consultation with Sudan and final review of the 2005 staff-monitored program, and the 2005 staffmonitored program, the following documents have been released and are included in this package:

- the staff report for the 2005 Article IV consultation, final review of the 2004 staff-monitored program, and the 2005 staff-monitored program, prepared by a staff team of the IMF following discussions that ended on December 20, 2004, with the officials of Sudan on economic developments and policies. Based on information available at the time of these discussions, the staff report was completed on April 15, 2005. The views expressed in the staff report are those of the staff team and do not necessarily reflect the views of the Executive Board of the IMF.

- a Public Information Notice (PIN) summarizing the views of the Executive Board as expressed during its April 29, 2005 discussion of the staff report that concluded the Article IV consultation.

- $\quad$ a statement by the Executive Director for Sudan.

The documents listed below have been or will be separately released.

Financial System Stability Assessment

Letter of Intent sent to the IMF by the authorities of Sudan*

Memorandum of Economic and Financial Policies by the authorities of Sudan*

Selected Issues Paper and Statistical Appendix

Technical Memorandum of Understanding*

* May also be included in Staff Report

The policy of publication of staff reports and other documents allows for the deletion of market-sensitive information.

To assist the IMF in evaluating the publication policy, reader comments are invited and may be sent by e-mail to publicationpolicy@imf.org.

\author{
Copies of this report are available to the public from \\ International Monetary Fund • Publication Services \\ $70019^{\text {th }}$ Street, N.W. • Washington, D.C. 20431 \\ Telephone: (202) 623-7430 • Telefax: (202) 623-7201 \\ E-mail: publications@imf.org •Internet: http://www.imf.org
}

Price: $\$ 15.00$ a copy

\author{
International Monetary Fund \\ Washington, D.C.
}


This page intentionally left blank

CInternational Monetary Fund. Not for Redistribution 


\section{INTERNATIONAL MONETARY FUND}

\section{SUDAN \\ Staff Report for the 2005 Article IV Consultation, Final Review of the 2004 Staff-Monitored Program (SMP), and the 2005 Staff-Monitored Program}

Prepared by the Middle East and Central Asia and Policy Development and Review Departments

Approved by Lorenzo L. Pérez and Matthew Fisher

April 15, 2005

Contents

Page

Executive Summary

I. Introduction $\underline{5}$

II. Recent Economic Developments and Performance Under the Program ........................ $\underline{6}$



A. Stocktaking of Performance and Key Challenges ................................................. 9

B. Macroeconomic Program for 2005 ..............................................................

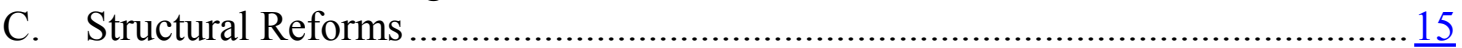

D. Medium-Term Outlook and Implications of the Peace Agreement....................... $\frac{17}{18}$

E. Debt Service and Relations with External Creditors ............................................. $\frac{18}{19}$

F. Data Issues and Technical Assistance ..........................................................

G. Program Monitoring and Risks.......................................................................

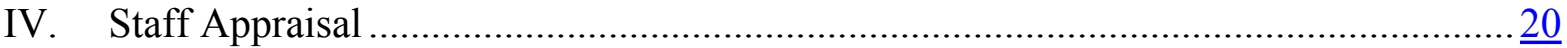

Text Boxes

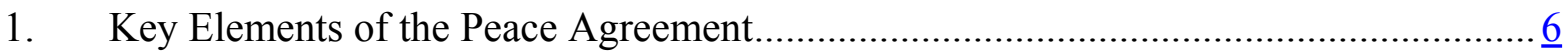

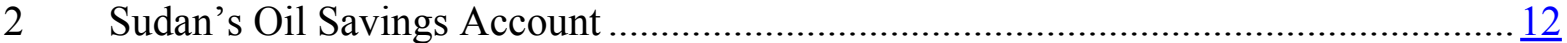

3. Economic Growth over the Medium Term.......................................................... 17

Text Tables

1. Central Government Operations, 2001-04 _........................................................ $\frac{7}{8}$

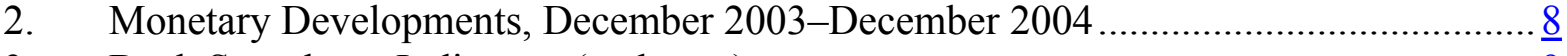

3. Bank Soundness Indicators (end-year) ………….............................................

4. Medium-Term Fiscal Expenditures ………………............................................. 18 


\section{Figures}

1. GDP, Prices, External, and Fiscal Developments, 2000-05 .................................. 23

2. Exchange Rate Indices and International Reserves, January 2000-December $2004 \ldots \underline{24}$

3. Monetary Developments, December 2002-December 2004 ................................... 25

\section{Tables}

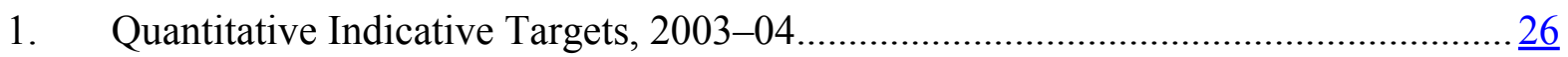

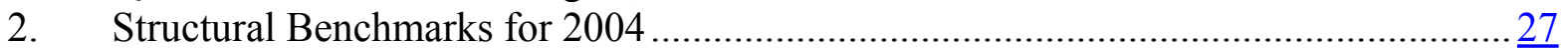

3. Selected Economic and Financial Indicators, 2001-05 .......................................... $\frac{28}{29}$

4. Summary Balance of Payments, 2003-08 ............................................................. 29

5. Central Government Operations, 2001-05 …...................................................... $\underline{30}$

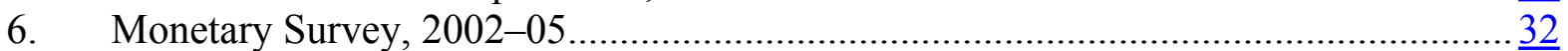

7. Monetary Authorities' Accounts, 2002-05 ......................................................... $\frac{33}{34}$

8. Medium-Term Macroeconomic Scenario, 2004-10 ................................................ $\frac{34}{34}$

9. Indicators of Debt Service Capacity, 2002-05 …................................................ $\underline{35}$

10. External Financing Requirements and Sources, 2003-05 ................................... $\underline{36}$

11. Millennium Development Goals, 1990-2002 ................................................... 37

\section{Appendices}

I. Relations with the Fund ............................................................................ $\frac{38}{41}$



III. Statistical Issues ...................................................................................... $\frac{43}{49}$

IV. Tentative Work Program, 2005 ...................................................................... 49

Attachments

I. Letter of Intent, Memorandum of Economic and Financial Policies, and Technical Memorandum of Understanding ................................................................... $\underline{50}$

II. Public Information Notice .................................................................... 65 


\section{LIST OF ACRONYMS}

$\begin{array}{ll}\text { AfDB } & \text { African Development Bank } \\ \text { AFTA } & \text { Arab Free Trade Area } \\ \text { AMF } & \text { Arab Monetary Fund } \\ \text { BOS } & \text { Bank of Sudan } \\ \text { CAR } & \text { Capital Adequacy Ratio } \\ \text { COMESA } & \text { Common Market for Eastern and Southern Africa } \\ \text { FDI } & \text { Foreign Direct Investment } \\ \text { FSAP } & \text { Financial Sector Assessment Program } \\ \text { GDDS } & \text { General Data Dissemination System } \\ \text { GFS } & \text { Government Finance Statistics } \\ \text { HIPC } & \text { Heavily-Indebted Poor Countries } \\ \text { IFAD } & \text { International Fund for Agricultural Development } \\ \text { IsDB } & \text { Islamic Development Bank } \\ \text { JAM } & \text { Joint Assessment Mission } \\ \text { MDG } & \text { Millennium Development Goals } \\ \text { MOFNE } & \text { Ministry of Finance and National Economy } \\ \text { OPEC } & \text { Organization of Petroleum Exporting Countries } \\ \text { OSA } & \text { Oil Savings Account } \\ \text { RAP } & \text { Rights Accumulation Program } \\ \text { SMP } & \text { Staff-Monitored Program } \\ \text { SPLM } & \text { Sudan People's Liberation Movement } \\ \text { WTO } & \text { World Trade Organization }\end{array}$




\section{EXECUTIVE SUMMARY}

During the last four years, Sudan has implemented an important economic agenda, with emphasis on strengthening institutions and mobilizing domestic resources. This agenda, supported by successive staff-monitored programs, included prudent monetary and fiscal policies, the liberalization of the trade and investment regimes, privatization and public enterprise restructuring, tax reforms, and deregulation of the foreign exchange market.

Economic performance has been promising. Between 2001 and 2004, the economy grew at an average rate of 6.4 percent per year, the non-oil sector expanded at an annual rate of 5.3 percent, inflation was kept at single-digit levels, and investment rose from 17.6 percent of GDP to 22.6 percent. Higher revenues turned the fiscal balance into surplus, and higher exports helped to rebuild international reserves and allowed for an expansion in government spending. However, expenditure restraint was needed to ensure macroeconomic stability and resources proved insufficient to fund social and development programs.

In January 2005, the government and the Sudan People's Liberation Movement (SPLM) signed a comprehensive peace agreement that ended a 20 -year civil war. However, the situation in Darfur remains fragile and peace talks between the government and Darfur rebels have made little progress so far.

Notwithstanding the progress achieved so far, substantial challenges remain. Social and infrastructure spending should be scaled-up, and as the recent peace agreement with the south puts pressure on the fiscal accounts, donor support will be critical to meet poverty reduction goals. Intra-governmental coordination (including with the south) should be enhanced and emphasis placed on strengthening institutions to ensure the success of decentralization policies. In addition, variable private transfers, oil receipts, and aid flows pose a challenge to the conduct of monetary and fiscal policies. Lastly, the 2004 FSAP exercise revealed an improving trend in most indicators of banks' financial sector soundness, although several weaknesses remain.

The program for 2005 is based on prudent financial policies. The program will need to be adjusted by mid-year to reflect additional financing arising from higher oil prices and aid and previously unfunded expenditures on social and infrastructure projects. Real GDP growth and inflation are projected at about 8 and 7 percent, respectively. The structural reform agenda aims at strengthening the monetary policy regime, cash management, and fiscal and oil sector transparency. While a postponement of tax and trade policy reforms is understandable, earliest possible action by the authorities on these areas is still necessary. Furthermore, regularizing relations with creditors should be a priority and nonconcessional borrowing should be avoided.

Overall, the staff considers that the recent policy performance and commitments under the 2005 SMP are in line with what would be required under a RAP. 


\section{INTRODUCTION}

1. A staff team visited Khartoum from December 8 to 20,2004, to conduct the 2005 Article IV consultation discussions, the final review of performance under the 2004 Staff-Monitored Program (SMP), and discuss the 2005 SMP as well as the authorities' medium-term reform agenda. ${ }^{1}$

\section{The thrust of the policy advice in the last Article IV consultation has been} broadly implemented. In concluding the 2003 Article IV consultation on October 31 , 2003, Directors commended the authorities for the progress achieved with macroeconomic stabilization and economic reforms. Directors emphasized the need to improve tax revenues, maintain the deficit target amidst spending pressures, and ensure exchange rate flexibility. During a subsequent Executive Board meeting on June 16, 2004, Directors commended the authorities for the satisfactory implementation of the SMP. Similar to their assessment about the 2002 and the 2003 SMPs, most Directors considered the quality of policies envisaged in the 2004 SMP as equivalent to those required under a Rights Accumulation Program (RAP). ${ }^{2}$

3. The government and the SPLM signed a comprehensive peace agreement that ended 20 years of civil war on January 9, 2005. The two parties have begun working on the implementation of the agreement that envisages, among other things, political power sharing in a new national government, security arrangement, and a resource-sharing framework (Box 1). The UN is considering sending a peacekeeping force to monitor the implementation of the agreement.

\section{The situation in Darfur remains fragile and progress on peace talks between} the government and rebel forces has been slow. According to a recent UN report, ${ }^{3}$ the humanitarian situation in Darfur remains dire and the lack of security in this vast region continues to undermine relief efforts. Ceasefire violations have been reported on both sides from time to time. The African Union has a monitoring force in the region and is working to convene a new round of peace talks.

\footnotetext{
${ }^{1}$ The staff team included Messrs. Shabsigh (head), Ilahi, Hussein, Al-Ghelaiqah, Ms. Huckstep (all MCD), Mr. Hussain (PDR) and Messrs. Nallari and Park (World Bank). Mr. Gelbard, the incoming mission chief, participated in the first half of the mission. The mission met with Minister El-Zubeir Ahmed El-Hassan and State Minister Abda Yahia El Mahdi (Ministry of Finance, Governor Sabir Mohammad Hassan (BOS), and other government officials.

${ }^{2}$ Most Directors noted that the strength of SMPs should be taken into account in determining the period of a RAP.

${ }^{3}$ Report of the International Commission of Inquiry on Darfur to the United Nations Secretary-General, January 2005.
} 


\section{Box 1. Key Elements of the Peace Agreement}

- The agreement envisages the formation of a government of national unity by mid 2005 and calls for nationwide general elections during the "interim period" (six years). It also stipulates the right of the people of south Sudan to vote at the end of the interim period on whether to remain in Sudan or to become an independent state.

- The power-sharing agreement provides for a largely autonomous southern Sudanese government, with participation in the national government and civil service, a new national constitution, a new bi-cameral parliament, and the restructuring of national institutions. The agreement calls for a general election in three years.

- The wealth-sharing agreement establishes a framework for sharing and managing oil resources, delineates taxation powers between the national and southern governments, allows conventional banking in south Sudan (at present only Islamic banking is allowed in Sudan), provides for the introduction of a new national currency, establishes a process to address land claim issues, and organizes the relations of the national and southern governments with external donors. The agreement establishes a national petroleum commission responsible for managing the oil sector, confirms the principle of saving part of the oil revenue, provides 2 percent of net oil revenues to oil producing states, and divides the remaining net oil revenues (from oil wells producing in the south) equally between the national and southern governments.

- The protocol on security allows the two parties to maintain their own armed forces during the interim period, separated by a UN force, and establishes a new joint force that would become the nucleus of a future national army, as the two parties gradually downsize their forces.

- A separate protocol covers the three conflict areas bordering the south: Abyei, Southern Kordofan, and Blue Nile (also referred to as the Three Areas). The protocol provides special power, resource, and security arrangements to these areas, including a referendum on whether to join the south at the end of the interim period.

\section{Recent Economic Developments And Performance Under the Program}

5. Performance under the 2004 SMP was satisfactory. All quantitative benchmarks for end-December 2004 were met except the one on contracting or guaranteeing nonconcessional external debt (Table 1). During 2004, Sudan paid the Fund US\$32.4 million, compared to US\$30 million envisaged under the program. Most of the structural measures scheduled for implementation by end-December 2004 were implemented although many were delayed (Table 2).

\section{The economy grew strongly in 2004, although there was a small increase in} inflation. Real GDP rose from 6 percent in 2003 to 7.3 percent in 2004, owing to strong performance in the oil, manufacturing, construction, power, and services sectors. Higher oil production capacity led to a 21 percent expansion in the sector's GDP. Average inflation rose to 8.4 percent in 2004 compared to 7.7 percent in 2003 because of a loose monetary policy during the first half of 2004 (Table 3).

\section{The balance of payments improved reflecting higher exports, transfers, and} foreign direct investment (FDI). On a cash basis, the external current account deficit 
declined to an estimated 4.1 percent of GDP compared to about 5 percent in 2003, because of substantially higher oil export receipts as well as a strong recovery in non-oil exports. Oil exports grew by about 50 percent in 2004, while non-oil exports grew by 37 percent led by growth in exports of sesame seeds and livestock. In addition, FDI and private transfers rose to US\$2.5 billion - more than one-third higher than in 2003 - owing to a stable macroeconomic environment, improving trade integration, and the expansion of the oil sector. These favorable developments allowed for a buildup of foreign exchange reserves from 1.5 months of imports at end-2003 to 2.9 months at end-2004 (Table 4).

\section{The dinar appreciated in 2004 in the context of greater exchange rate}

flexibility. The dinar appreciated by 3.4 percent vis-à-vis the U.S. dollar and by 7.7 percent in real effective terms. The appreciation reflects the stronger balance of payments position, more flexible exchange rate arrangements, and monetary policy actions by the Bank of Sudan (BOS). The widening of the range of daily exchange rate fluctuations to \pm 3 percent and the easing of some of the restrictions on the amount of foreign exchange traded by banks have increased exchange rate flexibility. In addition, the BOS lifted exchange controls, including export surrender requirements on oil services, the prohibition for banks to issue foreign currency letters of guarantee, and restrictions on the transfer of funds by nonbanks. The BOS also sold foreign exchange in open market operations to moderate the growth of money supply in the second half of the year.

\section{Despite higher spending, higher fiscal revenues (oil and non-oil) have turned} the overall fiscal balance into surplus. In 2004, the overall balance recorded a surplus of 1.3 percent of GDP compared to a deficit of 1.2 percent under the program and a surplus of 1.0 percent in 2003 (Table 5). The accumulation of deposits in the oil savings account (OSA) was higher than programmed by 0.5 percent of GDP. The improved fiscal situation obviated the need for new net domestic financing.

\section{Fiscal revenues reached 21.5 percent of GDP compared to a program}

projection of 18.7 percent. Non-oil revenues rose from 8 percent of GDP in 2003 to more than 10 percent in 2004 (compared to a projected 9 percent), largely because of improved efficiency from the new large taxpayers' unit, a reduction in exemptions, and a telecom license fee. Oil revenues rose because of higher production and higher oil prices.

\section{Expenditures rose because of unanticipated spending and capital}

\begin{tabular}{|c|c|c|c|c|}
\hline \multicolumn{5}{|c|}{$\begin{array}{l}\text { Sudan: Central Government Operations, 2001-04 } \\
\text { (In percent of GDP) }\end{array}$} \\
\hline & $\underline{2001}$ & $\underline{2002}$ & $\underline{2003}$ & $\underline{2004}$ \\
\hline Revenue & 11.0 & 12.1 & 16.8 & 21.5 \\
\hline Tax & 5.6 & 5.5 & 6.1 & 8.2 \\
\hline Nontax & 5.4 & 6.6 & 10.7 & 13.3 \\
\hline Of which: crude oil 1/ & 4.4 & 4.7 & 8.8 & 11.2 \\
\hline Expenditure & 11.9 & 13.0 & 15.8 & 20.2 \\
\hline Current & 9.6 & 9.9 & 12.7 & 14.8 \\
\hline Capital & 2.3 & 3.1 & 3.1 & 5.4 \\
\hline Overall balance (cash basis) & -0.9 & -0.8 & 1.0 & 1.3 \\
\hline Of which: OSA accumulation & $\ldots$ & 0.3 & 0.8 & 1.6 \\
\hline \multicolumn{5}{|c|}{$\begin{array}{l}\text { Sources: Sudanese authorities and Fund staff estimates. } \\
\text { 1/ Oil revenues are valued at international prices and not at the OSA } \\
\text { benchmark price. }\end{array}$} \\
\hline
\end{tabular}
outlays. Darfur-related security and relief spending was more than double the amount programmed (it reached 1.1 percent of GDP). The additional spending was approved 
through a supplementary budget and was financed by using part of the additional oil revenues.

12. The BOS tightened monetary conditions in the second half of 2004 . Broad money grew at an annual rate of 37 percent in the first half of the year, but decelerated after the BOS took steps to mop up liquidity in the second half of 2004 to curb inflation. These steps included open market sales of securities and foreign exchange, an increase in the required reserves ratio from 12 percent to 14 percent, and the calling back of some loans extended to banks. By December, broad money growth had fallen to

\begin{tabular}{|c|c|c|c|c|}
\hline \multicolumn{5}{|c|}{$\begin{array}{l}\text { Sudan: Monetary Developments, December 2003-December } 2004 \\
\text { (In billions of Sudanese dinars) }\end{array}$} \\
\hline & $\frac{\text { Actual }}{2003}$ & $\frac{\text { Program }}{2004}$ & $\frac{\text { Actual }}{2004}$ & $\begin{array}{r}\text { Actual } \\
\text { Percentage } \\
\text { Change }\end{array}$ \\
\hline Reserve money & 354.8 & 426.5 & 453.3 & 27.8 \\
\hline NFA (excluding valuation adjustment & 247.1 & 337.9 & 449.9 & 82.1 \\
\hline NDA & 223.7 & 204.5 & 129.5 & -42.1 \\
\hline $\begin{array}{l}\text { Broad money } \\
\text { Of which }\end{array}$ & 734.1 & 917.6 & 960.4 & 30.8 \\
\hline Credit to government & 111.7 & 89.1 & 32.5 & -70.9 \\
\hline Credit to nongovernment & 312.1 & 417.6 & 451.9 & 44.8 \\
\hline
\end{tabular}
30.8 percent, compared with a program target of 25 percent (Table 6).

13. The authorities made progress in implementing structural reforms. On the fiscal front, a review of exemptions was completed and an action plan to streamline them is being developed. The tax privileges of the four major oil distribution companies lapsed at end-2004, and no new ones will be granted. The authorities indicated that technical capacity problems prevented the broadening of the definition of large taxpayers to include individuals. Instead, they plan to set up a medium-size taxpayer unit in 2005. The envisaged medium-term tariff reform program has been developed, but its implementation has been delayed until 2006 because of needs associated with the recent peace agreement. Regarding monetary and financial sector reforms, the BOS has improved the management and monitoring of liquidity and the mechanism for conducting open market operations. The mandated increase in the minimum capital requirement to SDD 3 billion (US\$12 million) has been completed. ${ }^{4}$ Some progress has also been made to improve oil sector transparency. The Auditor General Office has audited the accounts of Sudan Petroleum Corporation (SPC) and a report has been submitted to parliament. The Office is currently auditing the accounts of almost all SPC subsidiaries. However, there was little progress in aligning the SPC accounts with Sudan's commercial accounting standards

\section{Banking system indicators improved in 2004. The deposit base of} commercial banks expanded, allowing for an expansion of domestic credit that contributed 19 percentage points to the growth of the money supply. Returns on assets and on equity also improved, and the ratio of nonperforming loans fell slightly to 10.2 percent. As of December 2004, the central bank's measure of the banking system's compliance with

\footnotetext{
${ }^{4}$ Only one bank failed to comply with the required increase in capital.
} 
prudential norms rated 14 of the 24 banks in the system were as fair or better. The capital adequacy ratio (CAR) for the banking system as a whole increased to 10.8 percent from 9.9 percent in 2003.

\section{New nonconcessional debt was contracted in 2004, and the authorities} have prepared a new debt and borrowing strategy. In 2004, Sudan contracted or guaranteed US\$310 million loans or lines of

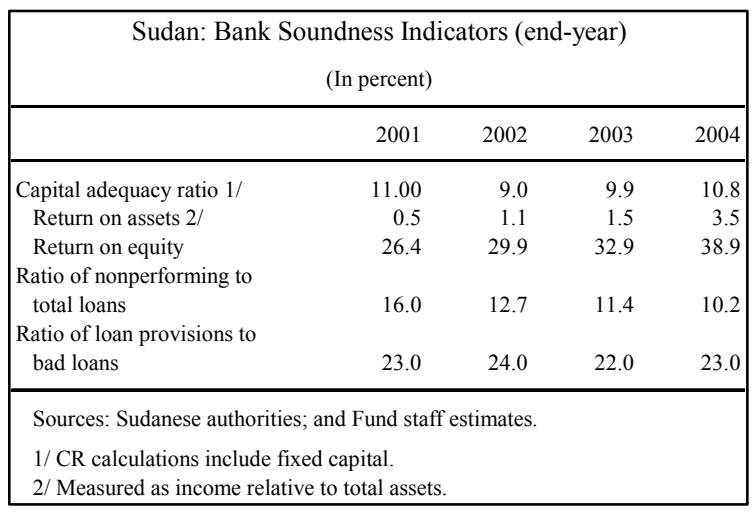
credit on nonconcessional terms. ${ }^{5}$ In the authorities' view, such financing was necessary to undertake critical investments (mostly in water and electricity), in the absence of access to concessional resources. However, recognizing the importance of strengthening debt management and rationalizing new borrowing, a new debt strategy and borrowing policy was prepared and is now awaiting approval by the Council of Ministers. The strategy emphasizes minimizing the contracting of external debt, which would be restricted to priority social projects.

\section{ARTICLE IV DiscuSSIONS}

16. The discussions, held against the background of the onset of the peace agreement with the south, focused on: (i) the economic challenges arising from peace in the south and the adequacy of the reforms already implemented in response to these challenges;

(ii) policies for 2005 to sustain economic growth and macroeconomic stability, while meeting the demands of the agreement with the SPLM; and (iii) the medium-term outlook and strategy. The discussions coincided with the conclusion of a Financial Sector Assessment Program (FSAP) mission.

\section{A. Stocktaking of Performance and Key Challenges}

\section{Under successive SMPs since 1997, Sudan has carried out an important economic stabilization and restructuring program. In fact, the set of policies} implemented since 2002 were similar in terms of stabilization policies and related structural reforms to other upper credit-tranche programs. Price controls were lifted, a number of economic activities were opened to the private sector, liberal foreign investment and exchange rate regimes were established, a privatization and enterprise-restructuring program was pursued, tariff protection was reduced, and most nontariff trade barriers were eliminated. In anticipation of the peace deal with the south, Sudan pursued over the past

\footnotetext{
${ }^{5}$ These include an Islamic Development Bank (IsDB) import financing (US\$22 million), an Arab Monetary Fund (AMF) loan (US\$45 million), a credit line from India (US\$50 million), and suppliers' credit for electricity, water, and transportation projects from China (US\$193 million). Assuming these loans are fully disbursed, average annual external debt service will increase by about 5 percent over the medium term.
} 
2-3 years a two-pronged strategy that emphasized strengthening economic policy institutions and mobilizing domestic resources. The authorities removed tax exemptions on a number of activities and rationalized the process for granting exemptions, improved tax administration, and introduced a large taxpayers' unit. Consequently, non-oil tax revenues rose from under 6 percent of GDP in 2002 to more than 8 percent in 2004.

\section{After decades of sluggishness, economic growth has averaged 6.5 percent per} year since 2001. The restoration of macro-stability in the late-1990s, subsequent economic reforms, and the emergence of the oil sector helped to increase domestic and foreign investment. Growth was relatively broad based, but it has been more prominent in the oil, construction, utilities, and agriculture sectors.

19. Higher oil exports have transformed the structure of the balance of payments. Oil exports have risen rapidly and they now account for about 80 percent of total exports. During a period that Sudan has had little access to foreign official assistance, oil has helped release the foreign exchange constraint, facilitated the rebuilding of international reserves, and allowed for a substantial expansion in government spending. In addition to higher oil revenues, tax reforms have mobilized a substantial amount of domestic resources.

\section{The reforms undertaken place Sudan in a favorable economic position} compared to many other post-conflict cases, but there are significant challenges ahead. The above-mentioned reforms were carried out largely without external assistance, but came at a price through restraint in social and development programs. The situation was exacerbated by the war in the south and the eruption of violence in Darfur since 2003. In an effort to address regional disparities and with a view to improve the targeting of social spending, the authorities have launched a countrywide decentralization program supported by a substantial increase in transfers to the states in 2005. The combined challenges of decentralization in terms of resource mobilization and capacity building, the mandates of the peace agreement with the south, the need to accelerate poverty reduction and development efforts in other states in north Sudan, and the stabilization and eventual reconstruction of Darfur are all formidable.

21. International donor support will be critical in the period ahead. The peace agreement between the government and the SPLM will enhance the favorable economic environment in Sudan and create the opportunity for additional mobilization of domestic resources and higher FDI. The agreement could also facilitate a political solution to the conflict in Darfur and resolving tensions in eastern states. ${ }^{6}$ With peace throughout the country, Sudan can begin to realize its full economic potential. The resource requirements for a successful post-conflict transition and effective poverty reduction to meet the

\footnotetext{
${ }^{6}$ There have been some disturbances in Eastern Sudan where rebel groups are demanding a larger share of resources and more power within the federal system.
} 
Millennium Development Goals (MDGs) will require additional donor support. ${ }^{7}$ A key part of this support should include the resolution to Sudan's external arrears and debt problems to allow the resumption of concessional financing by international financial institutions. The World Bank and the UN have carried out, with input from Fund staff, a Joint Assessment Mission (JAM) of Sudan's needs in 2005 and beyond. The findings of the JAM have recently been presented at a donors'conference hosted by Norway on April 11-12, 2005 , where donors pledged a total of about US\$1.9 billion for development assistance over the next three years. ${ }^{8}$

\section{The authorities reiterated their commitment to maintain macroeconomic}

stability. The authorities were well aware of the challenges facing Sudan and the uncertainties of donor assistance. They stressed their commitment to the pursuit of prudent policies and noted that they will take supportive actions as necessary. This commitment was evident in the design of the 2005 budget and other policies that maintained the focus on macroeconomic stability despite a large resource need. The authorities also agreed that institutional and capacity building would be as important as financial resources in achieving their economic objectives. They requested a significant increase in technical assistance and training support from the Fund.

\section{B. Macroeconomic Program for 2005}

23. The economic outlook for 2005 envisages somewhat higher output growth and a slight decline in inflation. Real GDP growth is projected to rise to 8.3 percent because of a significant increase in oil production and higher private and state spending on infrastructure. ${ }^{9}$ Non-oil real GDP growth may be subdued because of the effects of a weak rainfall on crop production. The program aims at containing average inflation at 7.5 percent for the year.

\section{The discussions took place amidst considerable uncertainty about financing} and fiscal needs for $\mathbf{2 0 0 5}$ and the medium term. The program discussed with the authorities and the 2005 budget is based on a price for Sudanese oil of US\$34 per barrel (consistent with the December 2004 WEO projection) ${ }^{10}$ and on a reduction in expenditure allocations for wages, emergency and federal development spending equivalent to 3 percent of GDP. This would result in a deficit of 0.6 percent of GDP. Such a conservative approach was taken because of uncertainties about oil-related flows and donor financing in 2005 and

\footnotetext{
${ }^{7}$ Two World Bank-managed multi-donor trust funds have been established to handle donor support in a coordinated fashion.

${ }^{8}$ An additional US\$2.6 billion was pledged for the direct delivery of humanitarian support.

${ }^{9}$ In 2005, new oil fields are expected to raise oil production by 34 percent to 390,000 barrels per day.

${ }^{10}$ Sudan's crude oil is somewhat heavier than typical traded brands and sells at about three dollars below U.K. Brent. The recent upward trend in futures' prices point to an average price of Sudan's oil of US $\$ 43$ per barrel in 2005.
} 
the need to accommodate a substantial increase in transfers to the south and to other regions associated with the peace agreement and decentralization policies.

\section{The budget envisages a worsening of the fiscal position in 2005, although the domestically financed deficit is expected to remain under one percent of GDP. Total} revenues are projected to rise bolstered by higher oil revenues, while expenditures will also increase because of higher transfers to the states. Oil revenues are expected to increase by about 2 percentage points of GDP compared to 2004 because of both higher production and higher oil prices. ${ }^{11}$ The OSA benchmark oil price has been raised to US\$30 per barrel compared to US\$24 in 2004. Under the OSA mechanism, oil revenues accruing from prices above US\$30 per barrel are expected to be saved in the OSA. The authorities continue to value the self-insurance provided by the OSA against unanticipated declines in oil revenues (Box 2). They consider that higher international oil prices and pressing needs justified raising the OSA price benchmark.

\section{Box 2. Sudan's Oil Savings Account}

The Oil Savings Account (OSA) was established in 2002 to protect government expenditures against volatile oil prices. Every year, a "benchmark" price of oil lower than international prices is established to finance the budget, while revenues above the benchmark price are deposited in the OSA. The government can make withdrawals from the OSA to cover expenditures if international prices fall below the benchmark price.

Since its inception, the OSA has accumulated a sizeable balance driven by the increase in output and international prices. Oil revenues rose from 4 percent of GDP in 2002 to 11 percent in 2004, and the equivalent of 2.5 percent of GDP has been saved in the OSA.

In addition to protecting and smoothing out government spending, the OSA has yielded additional benefits. First, the OSA has helped the authorities to suppress demands for unsustainable increases in government spending in periods of high oil prices. Second, expenditure restraint prevented an otherwise large real exchange appreciation associated with the oil boom. Third, by saving in the OSA and using domestic securities to finance the budget, the authorities have been able to contain the growth of high-powered money and inflation (this, in turn, has helped to jumpstart the domestic market for securities).

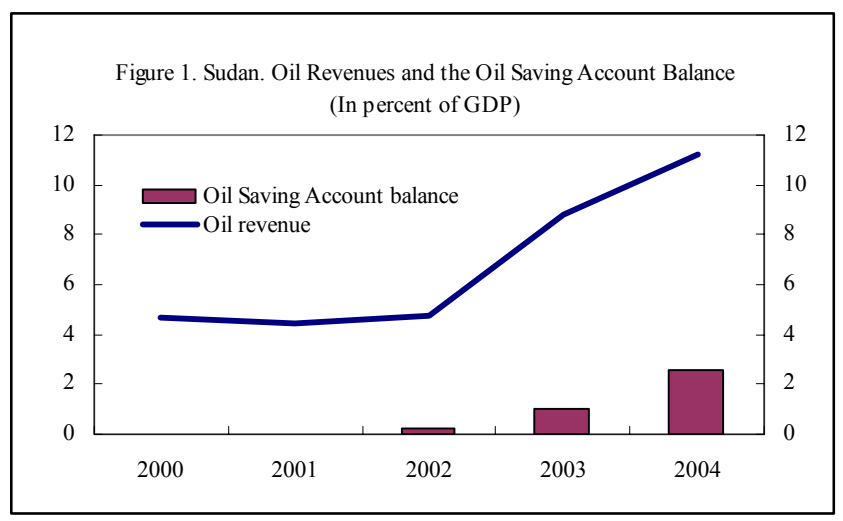

\footnotetext{
${ }^{11}$ If Sudan's oil prices remain at their level of recent months (the March 2005 WEO projection points to a price of US\$43 per barrel of Sudan's oil), actual revenues could increase by about 6 percentage points of GDP in 2005 , with almost one-half of the increase accruing to the south as stipulated in the peace agreement. However, there is considerable uncertainty about both oil production increments and oil prices for the remainder of the year as well as for the medium term.
} 
26. While oil revenues will rise, non-oil revenues are expected to fall slightly as a share of GDP. The authorities have reduced the excise tax on domestic petroleum products to protect consumers from the impact of the recent increase in oil prices. ${ }^{12}$ The staff argued that the timing for this reduction seemed inappropriate in light of impending fiscal pressures. The authorities expressed their concern that allowing a complete pass-through of higher international oil prices to consumers may undermine growth prospects and could be politically costly. The authorities also consider that after the substantial increase in non-oil tax revenues in 2004, it will not be feasible to introduce new tax measures in 2005 because of the political costs associated with raising taxes in the first year of implementation of the peace agreement.

27. On the expenditure side, transfers are expected to increase sharply while other priority expenditures await additional financing. The budget was originally formulated under a tight resource envelope, and it contains a large increase in transfers as well as expenditure reductions in several areas equivalent to about 3.5 percent of GDP. Transfers to the south are expected to be about 4.6 percent of GDP, while decentralization-related transfers to other states in the north will rise from 1.3 percent of GDP in 2004 to 3.4 percent in $2005 .^{13}$ A planned public sector wage increase in 2005 was postponed and allocations to social sectors, infrastructure, and general reserves were cut until additional financing could be identified.

\section{A mid-year supplementary budget is expected to accommodate unfunded} expenditure needs and take into account additional financing. If Sudan's oil price were to be updated in line with the March 2005 WEO projection, oil revenues would be higher than in the original budget by about 4 percentage points of GDP. The central government would count with additional resources equivalent to about 2.5 percentage points of GDP and the government of the south and other oil producing states will accrue the remaining revenue as stipulated in the wealth-sharing agreement. However, an accounting of the central government's unfunded priority social and infrastructure projects as well as a release of some of the expenditure restraint in the original budget could amount to 2-3 percentage points of GDP. These changes could turn the fiscal balance into surplus, the counterpart of which would be an additional accumulation of government deposits and international reserves at the central bank. The staff expects to discuss these issues with the authorities during the mid-year review and report to the Executive Board on any revisions to the program.


reflecting the impact of the peace agreement and the reintegration of south Sudan. Both oil

\footnotetext{
${ }^{12}$ In recent years, domestic retail prices were higher than comparable U.S. prices because of high taxes on petroleum products.

${ }^{13}$ Consistent with the spirit of the wealth-sharing agreement with the south, the authorities have launched a plan to foster fiscal federalism through transferring additional funds to the states.
} 
and non-oil exports are expected to grow rapidly. The latter will be led by growth in meat and cotton exports. Notwithstanding the strong export growth, imports are projected to grow at a faster pace, led by post-conflict related imports, particularly for food, construction material, transportation equipment, and emergency supplies. Investment-related imports are also projected to rise, including in the oil sector. The current account deficit will be partly financed by private capital inflows, some project financing, and humanitarian aid. Current account projections, however, are subject to considerable uncertainty. The projections discussed with the authorities (based on the December 2004 WEO projection) envisaged a financing gap of US\$365 million for 2005, but this number is likely to be lower once the effect of the now likely higher oil prices and previously unfunded priority projects are factored into the analysis.

\section{Sudan's external position remains vulnerable to potential shifts in oil prices} and private inflows. The authorities assured the mission that if additional revenues were needed they would be willing to take contingency measures including reversing the recent decrease in the excise tax. Imports also depend on the uncertainties of the new environment and emergency needs. To improve Sudan's ability to safeguard its external position, it is critical to continue building up international reserves in terms of import coverage.

\section{The monetary program is consistent with the growth and inflation objectives,} but significant uncertainties remain. Monetary policy targets a broad money growth of 28 percent, consistent with the growth and inflation objectives and with a structural increase in the demand for money reflecting the reintegration of the south. ${ }^{14}$ The authorities were concerned about the number of potential sources of monetary shocks in 2005, including large private capital inflows, oil export receipts, aid flows, and the introduction of a new currency. ${ }^{15}$ In addition, the large transfer of fiscal revenues to the south means that fiscal actions by the state government of south Sudan will also affect monetary developments. The mission concurred with this assessment and noted that active BOS monitoring and engagement with the markets and close coordination between the federal government and south Sudan will be essential for the smooth conduct of monetary policy. The monetary program will be reassessed by mid-year to take on board new developments.

\section{The authorities reiterated their commitment to a managed floating exchange} rate regime. The authorities, however, expressed some concern about the real effective exchange rate appreciation of 2004, which could continue in 2005 with rising oil exports receipts and other inflows. The mission pointed out that the current high growth rate of non-oil exports, coupled with Sudan's low labor costs, points to a strong external competitiveness. The latter could be further enhanced by a continued focus on lowering inflation, reducing distortions in the economy, and improving the business environment in

\footnotetext{
${ }^{14}$ The currency-to-deposits ratio is envisaged to rise from 44 percent in 2004 to 49 percent in 2005.

${ }^{15}$ The peace agreement entails issuing a new national currency. MFD has begun providing technical assistance in this area.
} 
general. Rationalizing the spending of oil revenue, through OSA savings, would also support the growth of non-oil sectors. The authorities expressed their intention to manage the exchange rate flexibly, occasionally intervening to prevent abrupt changes.

\section{Structural Reforms}

\section{Fiscal structural reforms will concentrate on strengthening tax revenues,} implementing an effective cash management system, and introducing the 2001 Government Finance Statistics (GFS) budget classification system. On tax administration, the focus will be on setting up a medium-size taxpayers' unit to broaden the tax base. The authorities intend to develop a plan to rationalize the tax incentive regime in light of the review of exemptions that was completed in 2004 and include the plan in the 2006 budget. In the area of financial management, the authorities have taken initial steps to ensure the autonomy of the cash management unit to schedule payments within a cash plan and to set up a single treasury account for the ministry of finance transactions in 2005 and for all other ministries in 2006. The staff feels that further technical assistance in these areas and strong commitment by the authorities will be necessary for a successful implementation of these reforms. ${ }^{16}$ The authorities plan to adopt the GFS methodology in the budgetary accounts by end 2006. ${ }^{17}$

\section{The staff emphasized the importance of strengthening monetary operations and} coordination with the fiscal authorities. Efforts will focus on strengthening the monetary operations unit at the BOS, which has begun providing recommendations on open market operations in line with Fund technical assistance. The authorities agreed on the importance of capacity building for effective short-term liquidity forecasting and coordination with fiscal operations. The mission also recommended open auction of government securities to increase the effectiveness of the BOS open market operations. In line with these changes, the BOS will begin, by mid-year, carrying out all of its short-term liquidity management with banks through securities.

35. The 2004 FSAP exercise revealed a number of high priority actions to deal with financial sector vulnerabilities. ${ }^{18}$ These included formulating a plan for banks to meet provisioning and capitalization requirements, improving data management at the central bank, revising the treatment of fixed assets in regulatory capital, organizing tenders for auctioning government certificates, improving coordination between on-site and off-site

\footnotetext{
${ }^{16}$ The World Bank is planning to launch a Public Expenditure Review (PER), which will also require participation from Fund experts.

${ }^{17}$ Fiscal data for 2001-2003 have been reclassified and a similar exercise is underway for the 2005 budget. For a pilot, two ministries and two states will keep accounts on both the current and GFS bases in 2005.

${ }^{18}$ See the accompanying paper "Sudan: Financial System Stability Assessment."
} 
supervision activities, and establishing a real time gross settlements system. ${ }^{19}$ Stress tests pointed to banking sector vulnerabilities to an economic slowdown. In addition, the legal and supervisory environment governing insurance and securities market should be enhanced for these sectors to contribute to financial deepening. Finally, the peace accord will imply the re-introduction of conventional banks in south Sudan, the restructuring of the central bank, and a revision of legislation. The authorities expressed broad agreement with the FSAP recommendations, intend to formulate an action plan to implement them, and have asked for technical assistance.

36. External sector reforms are expected to continue. Sudan's liberal nontariff barrier regime is expected to be maintained and the delayed three-year tariff reform program to be initiated in the context of the 2006 budget. The program will be designed and implemented in the context of Sudan's commitments under the Common Market for Eastern and Southern Africa (COMESA) and the Arab Free Trade Area (AFTA) agreement. The authorities have presented all the required documentation to the World Trade Organization (WTO) working party and prepared a complete legislative plan to amend and enact laws to comply with WTO agreements. The authorities also hope that a number of trade sanctions on Sudan can be lifted soon. Lastly, the authorities agreed to remove any exchange restrictions that may be identified as part of an ongoing review by MFD and LEG of Sudan's exchange system in connection with its acceptance of the obligations under Article VIII of the Fund's Articles of Agreement.

37. Oil sector transparency has been improving, but more needs to be done. While the auditor general has been auditing SPC accounts since 2001, the audit covers one of the largest sources of SPC income (the management fee from the government's share of oil revenues), but does not cover other sources. The mission urged a comprehensive audit and the aligning of the SPC and its subsidiaries' accounting system with commercial standards. The authorities agreed to implement such improvements in the context of the peace agreement that calls for major changes in oil sector management.

\footnotetext{
${ }^{19}$ Recent legislation and relevant BOS regulations establish the basic legal framework for anti-money laundering and combating the financing of terrorism, but implementation is lagging severely. Preventive measures need strengthening and enforcement, and regulations should be introduced for nonbank financial institutions and other relevant businesses. A single agency should be made responsible for carrying out the functions of a financial intelligence unit.
} 


\section{Medium-Term Outlook and Implications of the Peace Agreement}

\section{The authorities' medium-term vision focuses on poverty reduction, sustained} high economic growth, and macroeconomic stability. ${ }^{20}$ Structural reforms that enable private sector activities, coupled with investments in health, education, and infrastructure, would sustain long-term growth. Prudent fiscal and monetary policies should ensure macroeconomic stability while a reorientation of public expenditures would allow for increased spending on poverty-reducing programs. Policy implementation will be challenging and will require the strengthening of state institutions. Donor assistance will also be critical for achieving the medium-term objectives. The medium-term vision is part of Sudan's longer-term ambition to meet the MDGs. The MDG agenda will be demanding both in terms of growth and financing requirements, including debt relief and arrears clearance that will be necessary to facilitate the resumption of development lending by international financial institutions. $^{21}$

\section{Box 3. Economic Growth over the Medium Term}

The authorities' medium-term framework envisages two distinct phases in the growth process. During the next two years, growth will depend on a surge in oil production and in economic activity in the south. After 2007, growth will depend more on economic diversification as sectoral policy reforms yield results.

After sharp early growth, oil production is projected to taper off. The outlook does not assume new oil discoveries during 2007-09. Daily oil output is projected to peak at $1 / 2$ million barrels in 2006. Accordingly, the oil sector's growth contribution will rise sharply in 2005-06, but will subsequently decline.

Agriculture is expected to rebound over the 2004-09 period; its growth is projected to rise from 4.5 to 7 percent per year. In the early years, livestock expansion will fuel the sector's growth, while later irrigated agriculture will play a greater role. Other sectors will also grow rapidly fuelled by construction activity.

Higher levels of private and public investment and greater reliance on foreign savings would help achieve the medium-term growth rates. Gross investment is expected to rise by about 3 percentage points of GDP, reflecting substantial increase in public capital spending. A modest increase in government saving would allow for a medium-term recovery in private consumption.

39. Sudan's economic prospects are favorable, assuming peace and a continuation of the reform efforts. The medium-term outlook envisages growth of 8-9 percent per year, single-digit inflation, and rising international reserves. Imports will rise faster than exports earlier on because of post-conflict and emergency needs, leading to an initial worsening of the external current account and an improvement thereafter. Fiscal policy is expected to mobilize tax revenues, reorient expenditures toward social sectors, and support

\footnotetext{
${ }^{20}$ The medium-term vision, developed jointly by the government and the SPLM has been embedded in the World Bank-UN led Joint Assessment Mission report presented at the Oslo Donors' Conference.

${ }^{21}$ Total outstanding external obligations (most of it is debt contracted in the 1970s and 1980s and now in arrears), exceed US\$25 billion.
} 
decentralization. However, spending needs are considerable in light of the reconstruction and development needs of the south and considerable poverty throughout the national territory. The medium-term expenditure projections presented in Table 8 are based on the December 2004 oil price assumptions and do not take on board the additional needs associated with the recent peace agreement; most of these needs were recently estimated as part of the JAM exercise and are

\begin{tabular}{|c|c|c|c|c|c|}
\hline \multicolumn{6}{|c|}{$\begin{array}{l}\text { Sudan: Medium-Term Fiscal Expenditures } \\
\text { (In percent of GDP, unless otherwise noted) }\end{array}$} \\
\hline & 2006 & 2007 & 2008 & 2009 & 2010 \\
\hline \multicolumn{6}{|l|}{ Central government } \\
\hline Base case conditions 1 / & 25.5 & 25.9 & 26.2 & 26.3 & 25.1 \\
\hline Additional needs 2/ & 2.1 & 1.2 & 1.2 & 1.1 & 1.0 \\
\hline In millions of U.S. dollars 2/ & 575 & 376 & 427 & 442 & 457 \\
\hline \multicolumn{6}{|l|}{ States of south Sudan } \\
\hline Expenditure needs 3/ & 7.3 & 7.3 & 7.7 & 7.1 & 6.1 \\
\hline \multicolumn{6}{|c|}{$\begin{array}{l}\text { Sources: Joint Assessment Mission Report, April 2005, UN and the World Bank, } \\
\text { and IMF staff estimates. }\end{array}$} \\
\hline \multirow{2}{*}{\multicolumn{6}{|c|}{$\begin{array}{l}\text { 1/ Includes transfers to the states, but compresses central government expenditures and } \\
\text { excludes additional social and infrastructure spending compatible with the objective of } \\
\text { meeting the MDGs. }\end{array}$}} \\
\hline & & & & & \\
\hline \multirow{2}{*}{\multicolumn{6}{|c|}{$\begin{array}{l}\text { 2/ Includes higher social and infrastructure spending associated with the objective of } \\
\text { meeting the MDGs. Excludes costs of demobilization, reconstruction of Darfur, and } \\
\text { exteranl debt service due. }\end{array}$}} \\
\hline & & & & & \\
\hline $\begin{array}{l}\text { 3/ Excludes demobilization costs. } \\
\text { expected to cover between } 70 \text { and } 80\end{array}$ & $\begin{array}{l}\text { ransfers } \\
\text { f these e }\end{array}$ & $\begin{array}{l}\text { om the } \mathrm{c} \\
\text { penditur }\end{array}$ & tral gov & nment ar & \\
\hline
\end{tabular}
displayed in the text table above. Later this year, a consultation with World Bank staff, the staff will be discussing with the authorities a new medium-term economic framework that takes on board more recent oil price assumptions, new commitments from donors, and additional government spending (e.g., JAM estimated needs, demobilization expenditures).

\section{E. Debt Service and Relations with External Creditors}

40. Sudan's debt service capacity is increasing, but it remains modest. Sudan's external debt remains unsustainable and well above sustainable HIPC-initiative thresholds. At end-2004, the net present value of Sudan's debt is estimated at US\$24 billion or about 850 percent of the three-year average of exports of goods and services. To achieve external viability, Sudan will require comprehensive debt relief beyond traditional mechanisms. Owing to an improved external position, Sudan's external debt service capacity will improve in 2005, although the extent of the improvement will be dampened by the resource needs associated with the peace agreement. Still, if oil prices and private inflows were to be lower than expected, a sizable financing gap could still emerge.

41. Sudan plans to continue regularizing relations with its creditors. ${ }^{22}$ In 2004 , Sudan made partial debt service payments to almost all multilateral creditors, totaling about US\$96 million - of which one-third was paid to the Fund - compared with US\$88 million in 2003. Sudan paid US\$5 million to the World Bank and US\$6 million to the AfDB. Sudan's payments to other multilateral creditors resulted in new disbursements of

\footnotetext{
${ }^{22}$ Since the resumption of debt service payments to the Fund in 1997, Sudan has re-established relations with, and started partial repayments to, most of its multilateral creditors, as well as various bilateral Arab funds. In 2004, Sudan made partial payments on its obligations to the IMF, World Bank, African Development Bank (AfDB), AMF, IsDB, Arab Fund for Economic and Social Development, International Fund for Agricultural Development, and the OPEC Fund.
} 
US\$74 million. ${ }^{23}$ While keeping payments to multilateral creditors at the previous year's level, the authorities plan to make payments to some bilateral creditors in 2005 (mainly bilateral Arab funds). ${ }^{24}$ The largest debt service payments in 2005 would be to China (US\$158 million), primarily related to the Khartoum refinery investment loans and to Malaysia (US\$77 million). ${ }^{25}$

\section{The staff argued for higher payments to the Fund in 2005, but the authorities} requested that the level of payments be maintained at the level agreed for 2004 . The staff based its case on Sudan's improving debt service capacity (Table 9). The authorities indicated that, in light of uncertain financing flows and the impending request for donor assistance, payments to the Fund be maintained at the level agreed for 2004 (US\$30 million). They pointed out that the proposed level of payments is still US\$12.5 million greater than that required to stabilize Sudan's arrears. ${ }^{26}$ The authorities also expressed their expectation that, given the substantial reconstruction needs arising from the end of the recent civil war with the south, progress could be made on the clearance of Sudan's arrears and on subsequent debt relief under the HIPC initiative.

\section{F. Data Issues and Technical Assistance}

43. Sudan's economic data are sufficient for program monitoring, but gaps remain. Monetary, fiscal, and oil sector data have improved in recent years and Sudan is now participating in the Fund's General Data Dissemination System (GDDS). Regarding the oil sector, detailed information is available on both revenues and payments. However, fiscal expenditure data are still not compatible with GFS methodology, the compilation of national accounts is slow, and statistics on capital good imports and foreign direct investment are weak. In addition, information management within the BOS should be further developed. The authorities expressed interest in technical assistance from the Fund in these areas. ${ }^{27}$

\footnotetext{
${ }^{23}$ In 2005, multilateral creditors (excluding the IMF, World Bank, and AfDB) are expected to make new disbursements of about US\$135 million.

${ }^{24}$ In 2004, Sudan paid the Arab bilateral creditors about US\$20 million, but received new loans of US\$106 million for these creditors for critical infrastructure and social sector projects. In 2005, total debt service payments to Arab funds are projected at US\$30 million, while new disbursements from them are expected to be over US\$150 million.
}

${ }^{25}$ Since 1997, China provided about US\$1.2 billion in new loans to Sudan, including US\$910 million for the oil refinery and $\$ 150$ million for electricity projects. Debt service payments during 2002-04 amounted to US\$265 million. During 1997-99, Malaysia disbursed US\$225 million to Sudan, of which about half of the amount has been repaid by end-2004.

${ }^{26}$ However, this level will lower the ratios of payments to the Fund to net current receipts and to gross official reserves (Table 9).

${ }^{27}$ As part of the JAM exercise, the World Bank has also developed an assistance program for the Central Bureau of Statistics (CBS). 
44. Beyond the need to strengthen the quality of economic data, there are substantial technical assistance needs including in areas covered by the Fund. Since the beginning of the peace negotiations, Fund staff has provided technical assistance on different aspects of the revenue sharing agreement, the monetary and fiscal policy implications of the CPA, and the new currency. Looking ahead, technical assistance will be required on treasury modernization (including cash management), budget accounting and classification, fiscal decentralization, and consolidated budgeting. Follow-up assistance will also be needed on tax and custom administration. With respect to the financial sector, the priorities are the introduction of the new currency, the restructuring of the central bank, the introduction of a dual banking system, and monetary operations. The staffs of the Fund and the World Bank have begun working on a technical assistance program on financial sector areas.

\section{G. Program Monitoring and Risks}

\section{The staff-monitored program covers the period from January to December}

2005. Monitoring is based on semi-annual quantitative targets and structural benchmarks as described in the accompanying Memorandum of Economic and Financial Policies (MEFP, Attachment I). The program period will be one year, ending on December 31, 2005. Staff proposes to maintain the present cycle of semi-annual reviews for end-June and endDecember performance under the program. The staff will also report any significant developments or deviations from the program to the Board during informal country matters sessions.

46. The macroeconomic impact of the integration of the south, the extent of donor support, and unforeseen spending pressures are key risks to the program. The authorities are aware of these risks. They have sought technical assistance in estimating money demand, but uncertainties remain about the magnitude and impact of additional spending at the state level. They pointed out that the 2005 budget did not anticipate an increase in external assistance, but that substantial spending needs are still unmet, including on Darfur and demobilization. They indicated that if unexpected spending pressures arise, they would be willing to phase back in the oil excise tax. The possibility of higher-than-projected oil revenues will also provide additional cushion.

\section{Staff Appraisal}

47. The authorities' commitment to economic reforms is commendable. They have implemented a relatively broad-based reform agenda, maintained macroeconomic stability, and achieved high economic growth. These achievements should facilitate the transition to a peaceful and prosperous Sudan. Sudan should be able to mobilize increased levels of domestic resources that, coupled with international assistance, could be channeled to sustain high economic growth and reduce poverty. With an early resolution of the Darfur conflict, Sudan could quickly begin realizing its full economic potential. 
48. The authorities have adopted a prudent economic program for 2005 and their early move to restructure budgetary allocations in support of the peace-related needs is commendable. The policy package combines spending restraint and reasonable compromises in light of substantial pressures arising from the peace agreement with the south as well as the decision to press ahead with nationwide decentralization. Uncertainties remain, including about oil receipts and the extent of donor support. Latent expenditure pressures will need to be addressed, and if enough financing were not available, contingency measures, including reversing the decrease in the excise tax on petroleum products should be considered. These issues are expected to be addressed by mid-year and a supplementary budget prepared accordingly.

49. Further fiscal reforms are warranted to strengthen public expenditure management and generate additional revenues in the medium term. In this regard, the authorities should continue focusing on improving tax and customs administration and cash management, and reforming fiscal accounting to ensure full implementation of GFS methodology. The staff also urges the authorities to improve further oil sector transparency through the adoption of commercial accounting standards.

50. The oil savings account has served Sudan well; it provides a mechanism for saving oil revenues when prices are high, while ensuring priority expenditures in the event of a drop in revenue. These actions also help minimize the liquidity effects associated with the monetization of foreign exchange receipts. Furthermore, any residual financing of the budget through securities is noninflationary and contributes to the development of domestic money markets.

51. The stance of monetary policy is appropriate, but the authorities should be ready to tighten monetary conditions if inflationary pressures emerge. Staff welcomes the recent measures to improve the flexibility of the exchange rate and deems the managed float exchange rate regime appropriate at the current stage of Sudan's development.

52. The authorities' concerns about the potential difficulties for conducting monetary policy in 2005 and the need to monitor the appropriateness of the monetary targets in light of new developments are warranted. Building on recent reforms, future actions should focus on closely coordinating with the fiscal authorities (including at the state level) in improving the BOS short-term liquidity management capacity, and establishing market-oriented operations in government securities. The latter will be critical for developing a process that harmonizes monetary policy actions in a dual banking system. Finally, the authorities should develop a financial sector reform plan in line with the FSAP recommendations.

53. The decision to delay the launching of the second three-year tariff reform program to 2006 is understandable in light of fiscal needs in 2005. Nevertheless, the authorities need to finalize the program quickly to send a strong signal to domestic and foreign investors about Sudan's commitment to an open trade regime. Such reform will also help reduce distortions and increase competitiveness. At the same time, additional revenue measures 
should be identified and their implementation schedule coordinated with the tariff program to prevent a revenue loss.

54. The draft of the new debt strategy is a positive development, but the contracting of a number of nonconcessional loans in 2004 is a matter of concern. Even though Sudan's needs are high and it lacks access to concessional financing, the authorities should minimize nonconcessional borrowing to prevent aggravating the external debt overhang and complicate potential debt relief negotiations.

55. Overall, the staff considers that the policy commitments under the 2005 SMP are in line with what would be required for a RAP and provide a basis for a post-arrears clearance program, assuming that progress is achieved on securing financing assurances to resolve the arrears issue. As soon as the necessary financing assurances become available, the staff would recommend that in determining the timetable for arrears clearance, the Executive Board take account of the performance under successive SMPs since 2002.

56. Sudan's data are generally adequate for surveillance and program monitoring. It is proposed that the next Article IV consultation with Sudan be held according to the standard 12-month cycle. 
Figure 1. Sudan: GDP, Prices, External, and Fiscal Developments, 2000-05

Real GDP Growth, 2000-05

(In percent)

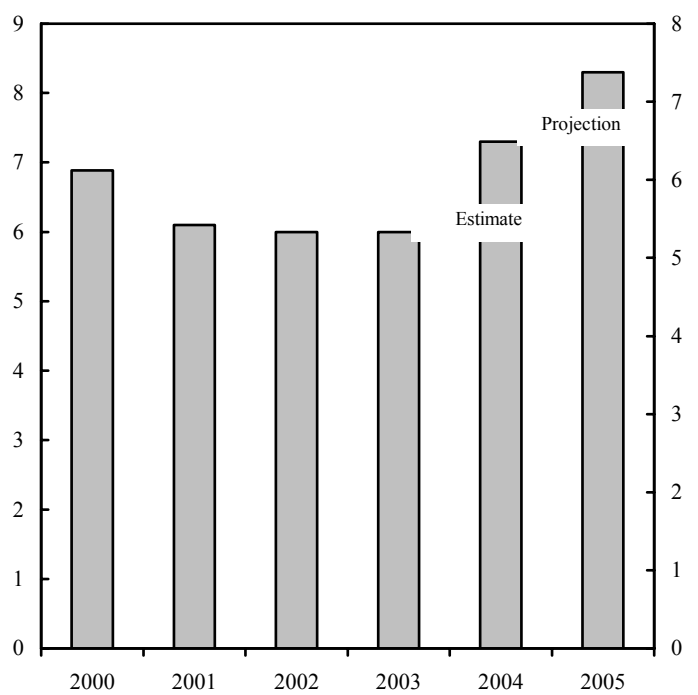

Current Account Balance,

Q1 2001-Q4 2004 (In millions of U.S. dollars)

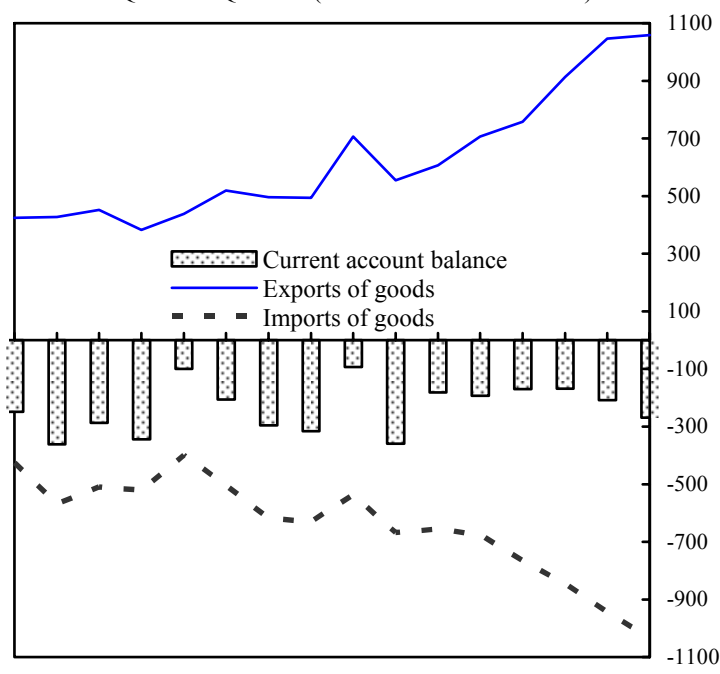

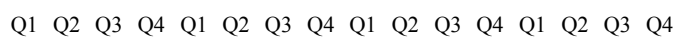
$\begin{array}{llllllllllllllll}01 & 01 & 01 & 01 & 02 & 02 & 02 & 02 & 03 & 03 & 03 & 03 & 04 & 04 & 04 & 04\end{array}$
Consumer Price Index, Dec. 2001-Dec. 2004

(12-month percent change)

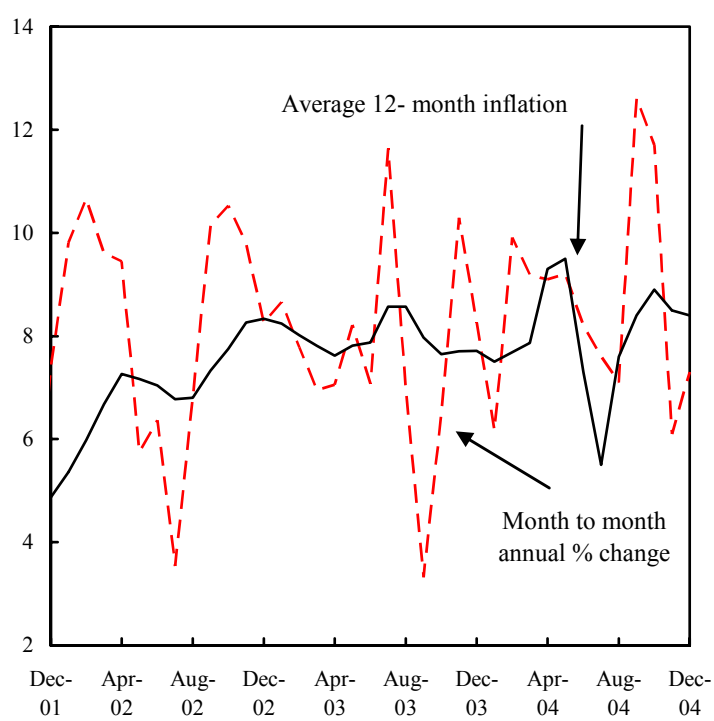

Government Revenue and Expenditures (Annualized basis, in percent of GDP)

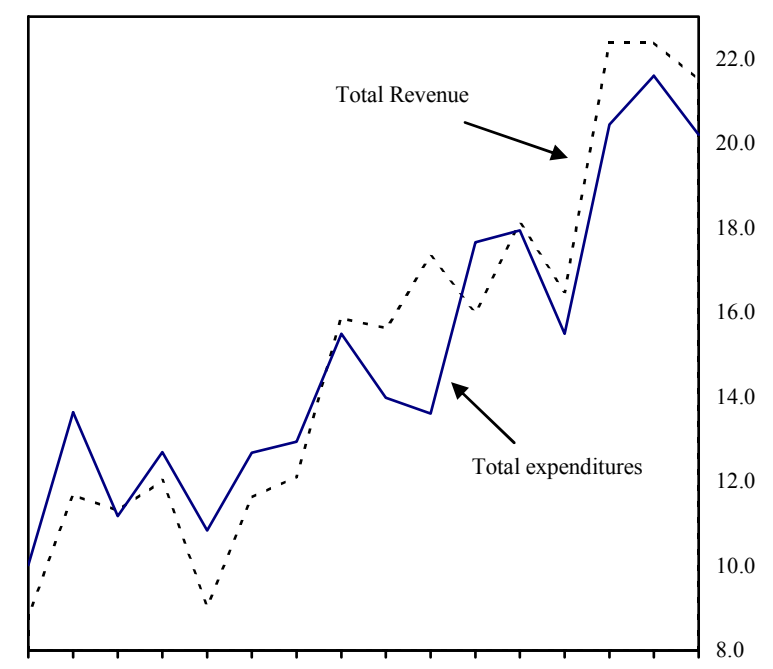

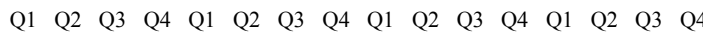
$\begin{array}{llllllllllllllll}01 & 01 & 01 & 01 & 02 & 02 & 02 & 02 & 03 & 03 & 03 & 03 & 04 & 04 & 04 & 04\end{array}$

Sources: Sudanese authorities; and Fund staff estimates. 
Figure 2. Sudan: Exchange Rate Indices and International Reserves, January 2000-December 2004
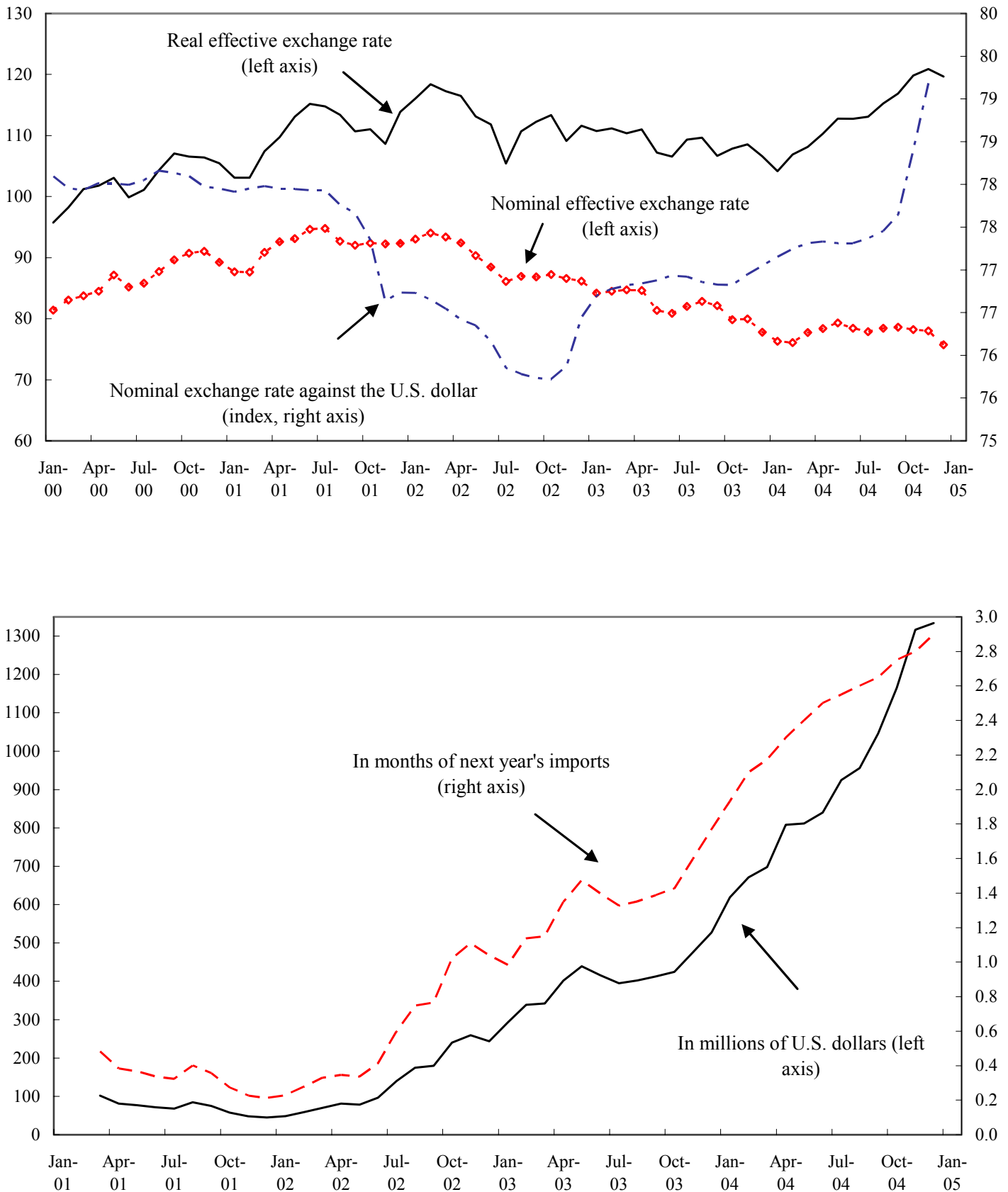

Sources: Bank of Sudan; and Information Notice System, IMF. 
Figure 3. Sudan: Monetary Developments, December 2002-December 2004

Money and credit (Annual growth rates, in percent)

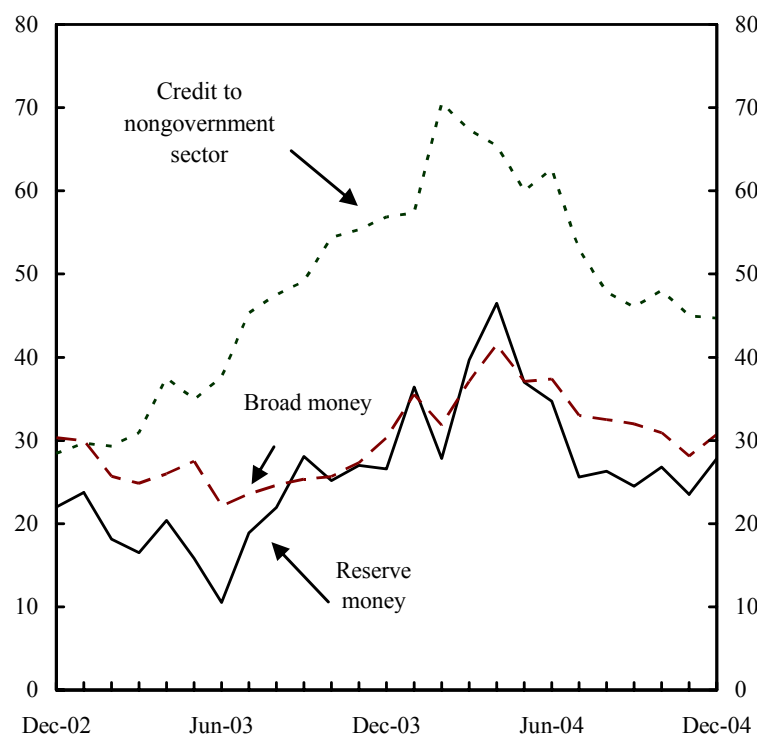

Composition of broad money (In billions of Sudanese dinars)

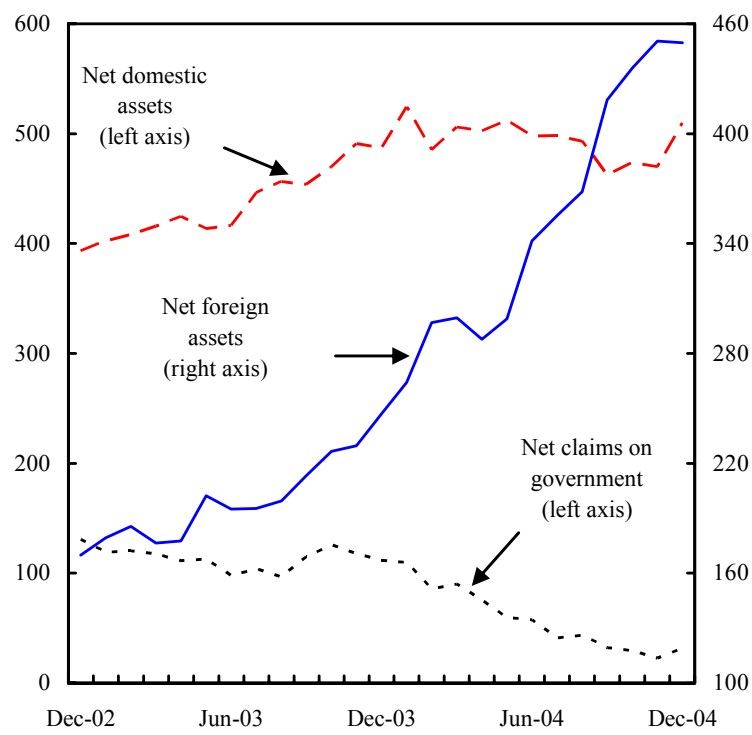

Sources: Bank of Sudan; and Fund staff estimates.
Cost of finance

(murabaha rate, in percent)
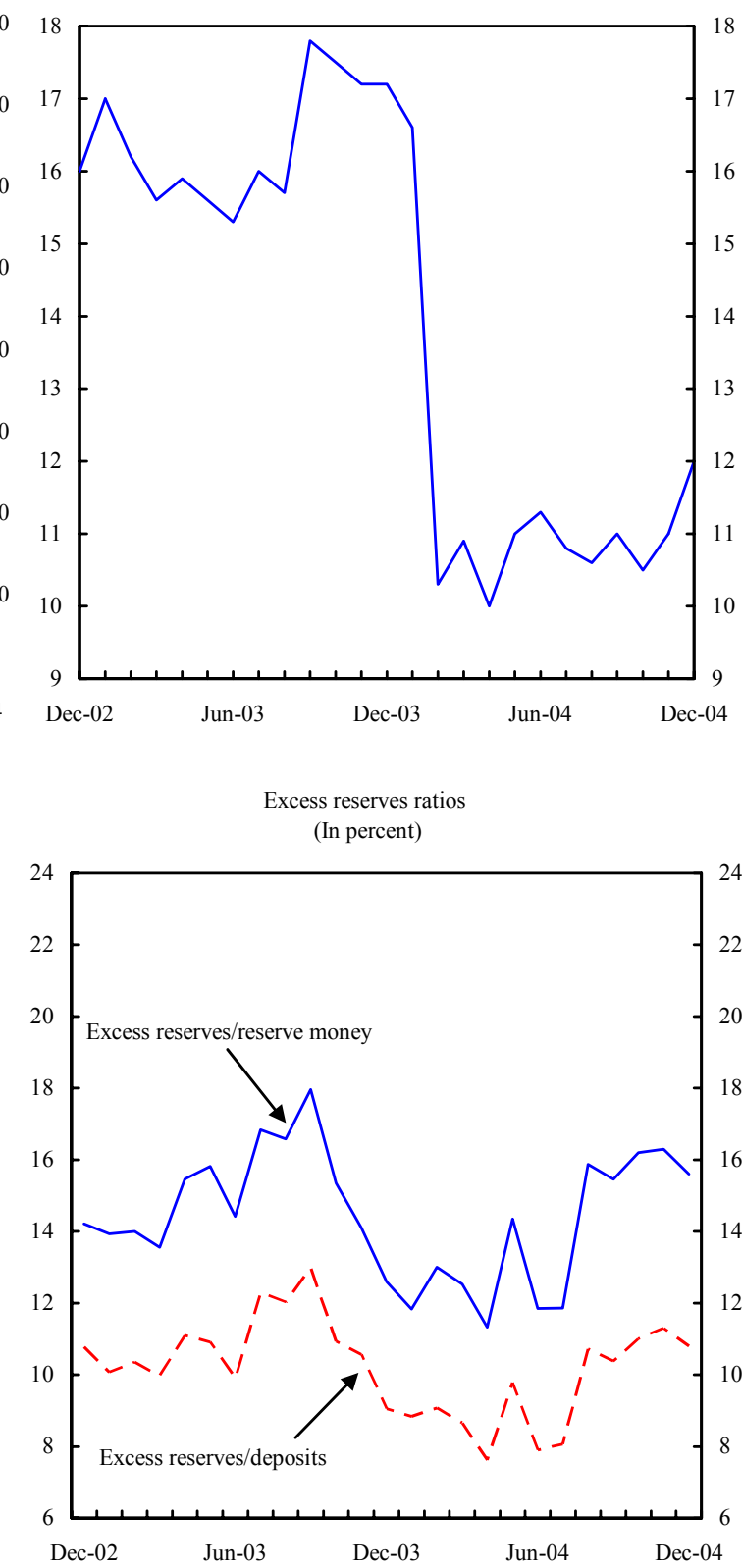
Table 1. Sudan: Quantitative Indicative Targets, 2003-04

(In billions of Sudanese dinars; unless otherwise indicated)

\begin{tabular}{|c|c|c|c|c|c|c|c|}
\hline & \multirow[b]{2}{*}{$\begin{array}{l}\text { Dec. } \\
2003\end{array}$} & \multicolumn{6}{|c|}{ Cumulative Change During 2004 1/ } \\
\hline & & $\begin{array}{c}\text { 3rd } \\
\text { Quarter }\end{array}$ & $\begin{array}{c}\text { 3rd } \\
\text { Quarter }\end{array}$ & $\begin{array}{c}\text { 3rd } \\
\text { Quarter }\end{array}$ & $\begin{array}{c}\text { 4th } \\
\text { Quarter }\end{array}$ & $\begin{array}{c}\text { 4th } \\
\text { Quarter }\end{array}$ & $\begin{array}{c}\text { 4th } \\
\text { Quarter }\end{array}$ \\
\hline & Actual 2/ & $\begin{array}{l}\text { Indicative } \\
\text { Target }\end{array}$ & $\begin{array}{c}\text { Program } \\
\text { w/adjustor }\end{array}$ & Actual & $\begin{array}{l}\text { End-year } \\
\text { Program }\end{array}$ & $\begin{array}{c}\text { Program } \\
\text { w/adjustor }\end{array}$ & Actual \\
\hline Bank of Sudan net domestic assets 3/ & 223.7 & 16.5 & -4.4 & -33.9 & 35.5 & 6.3 & -10.4 \\
\hline Domestic financing of the fiscal deficit 4/ & 98.7 & 8.5 & -12.1 & -89.8 & -10.6 & -39.8 & -100.4 \\
\hline $\begin{array}{l}\text { Contracting or guaranteeing of external nonconcessional } \\
\text { debt by government and BOS 5/ }\end{array}$ & 147.0 & 0.0 & 0.0 & 265.2 & 0.0 & 0.0 & 310.2 \\
\hline Gross official usable reserves (in millions of U.S. dollars) 6/ & 526.7 & 225.0 & 304.7 & 517.2 & 280.0 & 396.7 & 807.0 \\
\hline Payments to the Fund (in millions of U.S. dollars) & 27.0 & $\ldots$ & $\ldots$ & $\ldots$ & 30.0 & $\ldots$ & 32.4 \\
\hline Memorandum items: & & & & & & & \\
\hline Broad money $3 /$ & 734.1 & 105.0 & $\ldots$ & 146.7 & 161.5 & $\ldots$ & 226.4 \\
\hline Central government social expenditure 7/ & 53.0 & 34.0 & $\ldots$ & $\ldots$ & 86.4 & $\ldots$ & 88.4 \\
\hline Oil saving account & 45.2 & 44.1 & $\ldots$ & 64.7 & 54.6 & $\ldots$ & 84.7 \\
\hline
\end{tabular}

$1 /$ Cumulative change from end of the previous year.

2/ Outstanding stock at end-of year.

3/ Net BOS financing is defined as borrowing by the central bank from the BOS (including GMCs) minus central government deposits at the BOS (excluding deposits accumulation in the OSA).

4/ Defined as total net borrowing by the government, including net borrowing from the Bank of Sudan (including GMCs and changes in deposits of the central government with the BOS, but excluding the OSA), net sales of GMCs outside the BOS, revenues from privatization, and repayments of internal domestic debts.

5/ This indicative target applies not only to debt as defined in Point No. 9 of the Guidelines on Performance Criteria with Respect to Foreign Debt (Decision No. 12274-(00/85), August 24, 2000), but also to commitments contracted or guaranteed for which value has not been received. Debt will be deemed to be concessional when the currency-specific discount rate (determined by the market-related "commercial interest reference rates (CIRR)" as published by the OECD) applied to the contractual schedule of charges and principal payments, indicates a grant element of at least 35 percent. The indicative target excludes the financing of the Merowe hydropower project.

6 / Include foreign banknotes in the vaults of the BOS.

7/ Central government expenditure on medical care; health services; poor students' support; supplement to poor consumers of electricity; social and health insurance; water, health, and education development. 
Table 2. Sudan: Structural Benchmarks for 2004

\begin{tabular}{|c|c|}
\hline Policy Area & $\begin{array}{l}\text { Implementation } \\
\text { Status }\end{array}$ \\
\hline \multicolumn{2}{|l|}{ Prior Actions } \\
\hline $\begin{array}{l}\text { 1. Enforce a ban, through a ministerial decree distributed to all line ministers, on all discretionary tax } \\
\text { exemptions. }\end{array}$ & Done \\
\hline $\begin{array}{l}\text { 2. Constitute the cash management unit, appoint a cash release committee, and draft an action plan to } \\
\text { operationalize the unit. }\end{array}$ & Done \\
\hline 3. Adopt a two-year program to align the budget classifications with the GFS. & Done \\
\hline 4. Develop an action plan to reform the fiscal reporting system. & Done \\
\hline $\begin{array}{l}\text { 5. Establish a Debt Policy and Monitoring Committee to guide the formulation and implementation } \\
\text { of a debt strategy and to evaluate all new loans. }\end{array}$ & Done \\
\hline $\begin{array}{l}\text { 6. Prepare a time bound action plan to audit and consolidate the accounts of all subsidiaries of Sudan } \\
\text { Petroleum Corporation, and launch a program to align their accounting system with international } \\
\text { standards. }\end{array}$ & Done \\
\hline \multicolumn{2}{|l|}{ By end-June 2004} \\
\hline $\begin{array}{l}\text { 1. Prepare a fiscal budget cash plan on a monthly basis for the second half of } 2004 \text {. The cash plan } \\
\text { must be approved by the cash release committee, and presented to the Bank of Sudan (BOS). }\end{array}$ & Done \\
\hline 2. Begin to transfer VAT collected by customs to the taxation department on a daily basis. & Not Done $1 /$ \\
\hline 3. Activate the large taxpayers' unit. & Done \\
\hline 4. Classify, as a technical exercise, the 2004 budget sectors into the GFS. & Done \\
\hline 5. Adopt a universal taxpayer identification number. & Not Done \\
\hline \multicolumn{2}{|l|}{ By end-December 2004} \\
\hline $\begin{array}{l}\text { 1. Complete a review of all regulations and agreements that grant tax exemptions and develop an } \\
\text { action plan to streamline the regulations in the context of the } 2005 \text { budget. }\end{array}$ & $\begin{array}{l}\text { Review completed, but } \\
\text { action plan delayed because } \\
\text { of peace agreement. }\end{array}$ \\
\hline 2. Eliminate all tax privileges of the four major oil distribution companies. & Done \\
\hline 3. Broaden the definition of large taxpayers to include individuals. & Not done 2/ \\
\hline $\begin{array}{l}\text { 4. Develop a new three-year tariff reform program that will be implemented in the context of the } \\
2005 \text { budget. }\end{array}$ & $\begin{array}{l}\text { Reform program completed, } \\
\text { but implementation delayed } \\
\text { until } 2006 \text { to prevent the loss } \\
\text { of revenue in } 2005 .\end{array}$ \\
\hline $\begin{array}{l}\text { 5. Formulate an external debt policy of the public sector and have it approved by the Cabinet of } \\
\text { Ministers. }\end{array}$ & $\begin{array}{l}\text { External debt policy } \\
\text { approved by the Minister of } \\
\text { Finance, but it is awaiting } \\
\text { cabinet approval. }\end{array}$ \\
\hline
\end{tabular}

\footnotetext{
${ }^{1}$ Currently, this is done on a weekly basis.

2 The authorities intend to establish a medium taxpayers' unit by mid-2005.
} 
Table 3. Sudan: Selected Economic and Financial Indicators, 2001-05

\begin{tabular}{|c|c|c|c|c|c|}
\hline & 2001 & 2002 & 2003 & $\frac{\text { Est. }}{2004}$ & $\frac{\text { Prog. }}{2005}$ \\
\hline & \multicolumn{5}{|c|}{ (Annual changes in percent; unless otherwise indicated) } \\
\hline \multicolumn{6}{|l|}{ National income, production, population and prices } \\
\hline Nominal GDP (in billions of Sudanese dinars) & 3,376 & 3,876 & 4,425 & 5,138 & 5,973 \\
\hline Population (in millions) & 31.9 & 32.7 & 33.6 & 34.5 & 35.4 \\
\hline GDP per capita (in U.S. dollars) & 405 & 419 & 469 & 549 & 625 \\
\hline Real GDP growth & 6.1 & 6.0 & 6.0 & 7.3 & 8.3 \\
\hline Real non-oil GDP growth & 4.7 & 4.9 & 5.5 & 6.0 & 5.6 \\
\hline Average CPI inflation & 4.9 & 8.3 & 7.7 & 8.4 & 7.5 \\
\hline \multirow[t]{2}{*}{ CPI inflation (end of period) } & 7.4 & 8.3 & 8.3 & 8.4 & 8.0 \\
\hline & \multicolumn{5}{|c|}{ (In percent of GDP) } \\
\hline \multicolumn{6}{|l|}{ Investment and saving } \\
\hline Gross domestic investment & 17.6 & 19.4 & 20.0 & 22.6 & 24.4 \\
\hline Government & 2.2 & 2.9 & 2.9 & 5.1 & 6.8 \\
\hline Nongovernment & 15.3 & 16.5 & 17.1 & 17.5 & 17.7 \\
\hline Gross domestic saving & 9.9 & 13.4 & 15.7 & 18.5 & 20.3 \\
\hline Government & 2.1 & 3.4 & 5.4 & 7.7 & 7.2 \\
\hline Nongovernment & 7.8 & 10.0 & 10.3 & 10.8 & 13.1 \\
\hline \multicolumn{6}{|l|}{ Central government operations $1 /$} \\
\hline Total revenue & 11.0 & 12.1 & 16.8 & 21.5 & 22.6 \\
\hline Total expenditure & 11.9 & 13.0 & 15.8 & 20.2 & 23.2 \\
\hline \multirow[t]{2}{*}{ Overall balance (cash) $2 /$} & -0.9 & -0.8 & 1.0 & 1.3 & -0.6 \\
\hline & \multicolumn{5}{|c|}{ (Changes in percent of beginning broad money stock) } \\
\hline \multicolumn{6}{|l|}{ Money and credit } \\
\hline Net domestic assets & 30.8 & 6.6 & 16.7 & 3.2 & 14.0 \\
\hline Broad money & 24.7 & 30.3 & 30.3 & 30.8 & 28.0 \\
\hline Reserve money (change in percent) & 3.7 & 22.0 & 26.6 & 27.8 & 29.1 \\
\hline \multirow[t]{2}{*}{ Velocity $3 /$} & 7.2 & 6.9 & 6.0 & 5.3 & 4.9 \\
\hline & \multicolumn{5}{|c|}{ (In millions of U.S. dollars; unless otherwise indicated) } \\
\hline \multicolumn{6}{|l|}{ External sector } \\
\hline Exports, f.o.b. & 1,699 & 1,949 & 2,577 & 3,778 & 4,975 \\
\hline Imports, f.o.b & $-2,031$ & $-2,153$ & $-2,536$ & $-3,586.2$ & $-4,711.5$ \\
\hline Non-oil export volume (percent growth) & -27.1 & 41.7 & -9.0 & 14.8 & 7.1 \\
\hline Non-oil import volume (percent growth) & 31.6 & 5.6 & 9.2 & 35 & 31 \\
\hline Current account balance $1 /$ & $-1,289$ & -918 & -827 & -816.1 & $-1,408.5$ \\
\hline In percent of GDP & -9.9 & -6.2 & -4.9 & -4.1 & -5.9 \\
\hline Terms of trade (Index 1993 $=100$, change in percent) & -4.6 & -2.2 & 8.2 & 14.3 & -4.0 \\
\hline Real effective exchange rate (change in percent) $4 /$ & 8.0 & -2.0 & -4.5 & 7.7 & $\ldots$ \\
\hline Official exchange rate (end of period, SD/US\$) & 261.4 & 261.7 & 260.4 & 251.5 & $\ldots$ \\
\hline \multicolumn{6}{|l|}{ External debt service (in percent of current receipts) } \\
\hline Commitment basis & 38.4 & 24.1 & 24.2 & 18.3 & 16.0 \\
\hline Actual payments & 5.1 & 3.9 & 6.1 & 5.4 & 5.2 \\
\hline External debt (billions of U.S. dollars) & 20.9 & 23.6 & 25.7 & 26.2 & 26.5 \\
\hline Gross usable reserves (millions of U.S. dollars) & 44.9 & 248.7 & 526.9 & $1,333.5$ & $1,753.8$ \\
\hline In months of next year's imports & 0.2 & 1.0 & 1.5 & 2.9 & 3.2 \\
\hline Crude oil export price (U.S. dollars per barrel) & 22.0 & 23.0 & 27.0 & 36.4 & 34.0 \\
\hline
\end{tabular}

Source: Projections based on information provided by the Sudanese authorities; and Fund staff estimates.

1/ Cash basis.

2/ Including accumulation in the oil savings account (OSA).

3/ Defined as the ratio of GDP to end of period broad money.

4/ End of period. 
Table 4. Sudan: Summary Balance of Payments, 2003-08

\begin{tabular}{|c|c|c|c|c|c|c|c|}
\hline & \multirow{2}{*}{$\frac{\text { Actual }}{2003}$} & \multirow{2}{*}{$\frac{\text { Prog. }}{2004}$} & \multirow{2}{*}{$\frac{\text { Est. }}{2004}$} & \multicolumn{4}{|c|}{ Projections } \\
\hline & & & & 2005 & 2006 & 2007 & 2008 \\
\hline & \multicolumn{7}{|c|}{ (In millions of U.S. dollars; unless otherwise indicated) } \\
\hline Current account balance & $-1,457$ & $-1,199$ & $-1,446$ & $-2,107$ & $-2,370$ & $-2,725$ & $-2,992$ \\
\hline Current account balance (on cash basis) & -827 & -555 & -816 & $-1,409$ & $-1,681$ & $-1,984$ & $-2,221$ \\
\hline Trade balance & 40 & 217 & 192 & 264 & 666 & 606 & 434 \\
\hline Exports, f.o.b. & 2,577 & 3,615 & 3,778 & 4,975 & 6,414 & 7,037 & 7,566 \\
\hline Of which: Crude oil exports & 1,968 & 2,811 & 2,957 & 4,082 & 5,320 & 5,691 & 5,987 \\
\hline Imports, f.o.b. & $-2,536$ & $-3,398$ & $-3,586$ & $-4,712$ & $-5,748$ & $-6,431$ & $-7,132$ \\
\hline Services (net) & -794 & -933 & $-1,020$ & $-1,354$ & $-1,668$ & $-1,873$ & $-1,992$ \\
\hline Income (net) & $-1,422$ & $-1,541$ & $-1,741$ & $-2,153$ & $-2,631$ & $-2,821$ & $-2,880$ \\
\hline Receipts & 10 & 13 & 22 & 30 & 39 & 52 & 63 \\
\hline Non-oil payments & -691 & -716 & -725 & -782 & -782 & -837 & -872 \\
\hline Oil related expenses $1 /$ & -740 & -838 & $-1,038$ & $-1,401$ & $-1,888$ & $-2,037$ & $-2,070$ \\
\hline Current transfers (net) & 718 & 1,058 & 1,123 & 1,136 & 1,264 & 1,364 & 1,446 \\
\hline Of which: Private transfers & 708 & 1,014 & 1,095 & 1,102 & 1,216 & 1,304 & 1,381 \\
\hline Capital account & 0 & 0 & 0 & 0 & 0 & 0 & 0 \\
\hline Financial account (net) & 1,072 & 1,141 & 1,308 & 1,462 & 1,558 & 1,617 & 1,661 \\
\hline Disbursements & 85 & 255 & 191 & 290 & 316 & 236 & 201 \\
\hline Amortization & -239 & -280 & -280 & -290 & -301 & -311 & -321 \\
\hline Short-term capital flows (net) $2 /$ & 139 & 23 & -58 & 6 & 12 & 26 & 33 \\
\hline Net foreign assets of banks (increase -) & -5 & -56 & -26 & -40 & -40 & 0 & 0 \\
\hline Foreign direct investment and portfolio (net) & 1,092 & 1,199 & 1,481 & 1,496 & 1,571 & 1,665 & 1,749 \\
\hline Errors and omissions & 89 & 7 & 203 & 0 & 0 & 0 & 0 \\
\hline Overall Balance & -296 & -51 & 65 & -645 & -812 & $-1,108$ & $-1,330$ \\
\hline Change in official reserves (increase -) & -434 & -674 & -788 & -457 & -640 & -535 & -413 \\
\hline Of which: IMF (net) & -12 & -18 & -20 & -12 & -26 & -16 & -16 \\
\hline Exceptional financing & 730 & 724 & 722 & 736 & 729 & 795 & 850 \\
\hline Change in non-Fund arrears & 708 & 724 & 722 & 736 & 729 & 795 & 850 \\
\hline \multirow[t]{2}{*}{ Financing gap } & 0 & 0 & 0 & 365 & 722 & 849 & 892 \\
\hline & \multicolumn{7}{|c|}{ (In percent of GDP; unless otherwise indicated) } \\
\hline Memorandum items: & & & & & & & \\
\hline Current account & -8.6 & -6.1 & -7.3 & -8.8 & -8.7 & -8.7 & -8.4 \\
\hline Current account (cash basis) & -4.9 & -2.8 & -4.1 & -5.9 & -6.1 & -6.3 & -6.2 \\
\hline Current transfers (net) & 4.2 & 5.4 & 5.6 & 4.8 & 4.6 & 4.3 & 4.1 \\
\hline Of which: Private transfers & 4.2 & 5.2 & 5.5 & 4.6 & 4.4 & 4.2 & 3.9 \\
\hline Gross usable reserves (in million of U.S. dollars) & 527 & 1,142 & 1,334 & 1,754 & 2,350 & 2,870 & 3,266 \\
\hline \multirow[t]{2}{*}{ In months of next year's imports } & 1.5 & 2.7 & 2.9 & 3.2 & 3.8 & 4.2 & 4.4 \\
\hline & \multicolumn{7}{|c|}{ (Percent change, unless otherwise indicated) } \\
\hline Exports (value) & 32.2 & 40.3 & 46.6 & 31.7 & 28.9 & 9.7 & 7.5 \\
\hline Non-oil export (value) & 12.8 & 36.4 & 37.0 & 11.6 & 9.0 & 10.2 & 10.5 \\
\hline Imports (value) & 17.8 & 34.0 & 41.4 & 31.4 & 22.0 & 11.9 & 10.9 \\
\hline Terms of trade (non-oil exports and imports) & 13.7 & 1.0 & 18.2 & 1.9 & -0.4 & -0.4 & -1.3 \\
\hline Nominal GDP (in millions of U.S. dollars) & 16,957 & 19,546 & 19,913 & 23,891 & 27,373 & 31,365 & 35,572 \\
\hline Crude oil exports (volume, in thousands of barrels) & 72,921 & 80,650 & 81,261 & 120,072 & 152,038 & 169,983 & 181,438 \\
\hline Sudanese crude oil price (U.S. dollars per barrel) & 27.0 & 34.9 & 36.4 & 34.0 & 35.0 & 33.5 & 33.0 \\
\hline
\end{tabular}

Sources: Sudanese authorities; and Fund staff estimates and projections.

1/ Includes payments to oil companies as stipulated in production sharing arrangements.

2/ Net short-term trade and other credit facilities of the government and commercial banks. 
Table 5. Sudan: Central Government Operations, 2001-05

\begin{tabular}{|c|c|c|c|c|c|c|}
\hline & 2001 & 2002 & 2003 & $\frac{\text { Prog. }}{2004}$ & $2 \underline{\text { Est. }}$ & $\frac{\text { Proj. }}{2005}$ \\
\hline & \multicolumn{6}{|c|}{ (In billions of Sudanese dinars) } \\
\hline Total revenues & 370 & 471 & 742 & 937 & 1,105 & 1,348 \\
\hline Tax revenue & 189 & 213 & 270 & 372 & 421 & 467 \\
\hline Direct taxes & 41 & 41 & 52 & 69 & 75 & 95 \\
\hline Indirect taxes & 147 & 172 & 218 & 304 & 346 & 372 \\
\hline Nontax revenue & 181 & 257 & 472 & 565 & 684 & 881 \\
\hline Departmental fees & 10 & 13 & 11 & 20 & 14 & 19 \\
\hline National revenues & 171 & 244 & 461 & 545 & 670 & 862 \\
\hline Non-oil & 21 & 34 & 39 & 55 & 91 & 83 \\
\hline Oil & 150 & 211 & 423 & 490 & 579 & 779 \\
\hline $\mathrm{o} / \mathrm{w}$ Oil Saving Account (OSA) accumulation & $\cdots$ & 10 & 36 & 55 & 85 & 73 \\
\hline Total expenditure & 401 & 503 & 699 & 999 & 1,040 & 1,387 \\
\hline Current expenditure & 322 & 385 & 564 & 718 & 763 & 1,169 \\
\hline Chapter One (wages and salaries) & 132 & 165 & 191 & 264 & 274 & 301 \\
\hline Chapter Two (other current spending) & 166 & 187 & 321 & 354 & 405 & 369 \\
\hline Debt service paid & 26 & 51 & 73 & 65 & 81 & 70 \\
\hline Goods and services & 49 & 50 & 55 & 83 & 71 & 101 \\
\hline General reserve & 60 & 50 & 104 & 120 & 144 & 90 \\
\hline Other & 31 & 35 & 90 & 86 & 108 & 108 \\
\hline Chapter Three (current transfers to states) & 25 & 33 & 51 & 99 & 84 & 499 \\
\hline Capital expenditure & 79 & 119 & 135 & 282 & 277 & 218 \\
\hline Domestically financed $1 /$ & 73 & 109 & 113 & 173 & 227 & 135 \\
\hline Foreign financed & 5 & 10 & 22 & 109 & 50 & 83 \\
\hline Overall balance (cash basis) & -31 & -33 & 43 & -62 & 65 & -39 \\
\hline Financing & 31 & 33 & -43 & 62 & -65 & 39 \\
\hline Foreign financing $1 /$ & 5 & 10 & -15 & 74 & 5 & 57 \\
\hline Domestic financing & 39 & -133 & -18 & -11 & -100 & -18 \\
\hline BOS & 29 & -22 & -32 & -45 & -86 & -63 \\
\hline DMBs & 2 & -133 & 13 & 22 & 6 & 35 \\
\hline Nonbanks & 13 & 19 & 29 & 21 & 14 & 15 \\
\hline Domestic arrears repayments (-) & -7 & -8 & -30 & -15 & -34 & -15 \\
\hline Privatization & 3 & 11 & 2 & 6 & 0 & 10 \\
\hline Floats \& discrepancies & -14 & 156 & -9 & 0 & 30 & -1 \\
\hline
\end{tabular}


Table 5. Sudan: Central Government Operations, 2001-05 (Concluded)

\begin{tabular}{|c|c|c|c|c|c|c|}
\hline & 2001 & 2002 & 2003 & $\frac{\text { Prog. }}{2004}$ & 2004 & $\frac{\text { Proj. }}{2005}$ \\
\hline & \multicolumn{6}{|c|}{ (In percent of GDP) } \\
\hline Total revenues & 11.0 & 12.1 & 16.8 & 18.7 & 21.5 & 22.6 \\
\hline Tax revenue & 5.6 & 5.5 & 6.1 & 7.4 & 8.2 & 7.8 \\
\hline Direct taxes & 1.2 & 1.1 & 1.2 & 1.4 & 1.5 & 1.6 \\
\hline Indirect taxes & 4.4 & 4.4 & 4.9 & 6.0 & 6.7 & 6.2 \\
\hline Nontax revenue & 5.4 & 6.6 & 10.7 & 11.2 & 13.3 & 14.7 \\
\hline Non-oil & 0.6 & 0.9 & 0.9 & 1.1 & 1.8 & 1.4 \\
\hline Oil & 4.4 & 5.4 & 9.5 & 9.8 & 11.3 & 13.0 \\
\hline Of which: OSA accumulation & $\ldots$ & 0.3 & 0.8 & 1.1 & 1.6 & 1.2 \\
\hline Total expenditure & 11.9 & 13.0 & 15.8 & 19.9 & 20.2 & 23.2 \\
\hline Current expenditure & 9.6 & 9.9 & 12.7 & 14.3 & 14.8 & 19.6 \\
\hline Chapter one (Wages and Salaries) & 3.9 & 4.3 & 4.3 & 5.3 & 5.3 & 5.0 \\
\hline Chapter two (Other current spending) & 4.9 & 4.8 & 7.3 & 7.1 & 7.9 & 6.2 \\
\hline Debt service paid 3/ & 0.8 & 1.3 & 1.6 & 1.3 & 1.6 & 1.2 \\
\hline Goods and services & 1.4 & 1.3 & 1.2 & 1.7 & 1.4 & 1.7 \\
\hline General reserve & 1.8 & 1.3 & 2.3 & 2.4 & 2.8 & 1.5 \\
\hline Other & 0.9 & 0.9 & 2.0 & 1.7 & 2.1 & 1.8 \\
\hline Chapter three (Current transfers to states) & 0.7 & 0.8 & 1.2 & 2.0 & 1.6 & 8.4 \\
\hline Capital expenditure & 2.3 & 3.1 & 3.1 & 5.6 & 5.4 & 3.6 \\
\hline Domestically financed $1 /$ & 2.2 & 2.8 & 2.5 & 3.4 & 4.4 & 2.3 \\
\hline Foreign financed & 0.2 & 0.2 & 0.5 & 2.2 & 1.0 & 1.4 \\
\hline Overall balance (cash basis) & -0.9 & -0.8 & 1.0 & -1.2 & 1.3 & -0.6 \\
\hline Financing & 0.9 & 0.8 & -1.0 & 1.2 & -1.3 & 0.6 \\
\hline Foreign financing $1 /$ & 0.2 & 0.2 & -0.3 & 1.5 & 0.1 & 1.0 \\
\hline Domestic financing & 1.2 & -3.4 & -0.4 & -0.2 & -2.0 & -0.3 \\
\hline Bank of Sudan & 0.9 & -0.6 & -0.7 & -0.9 & -1.7 & -1.0 \\
\hline DMBs & 0.1 & -3.4 & 0.3 & 0.4 & 0.1 & 0.6 \\
\hline Nonbanks & 0.4 & 0.5 & 0.6 & 0.4 & 0.3 & 0.3 \\
\hline Domestic arrears repayments & -0.2 & -0.2 & -0.7 & -0.3 & -0.7 & -0.3 \\
\hline Privatization & 0.1 & 0.3 & 0.0 & 0.1 & 0.0 & 0.2 \\
\hline Floats and discrepancies & -0.4 & 4.0 & -0.2 & 0.0 & 0.6 & 0.0 \\
\hline \multicolumn{7}{|l|}{ Memorandum items } \\
\hline Non-oil revenue $2 /$ & 6.5 & 7.4 & 8.0 & 8.9 & 10.3 & 9.5 \\
\hline Crude oil revenue (excl. OSA) & 4.4 & 4.5 & 8.0 & 8.7 & 9.6 & 11.8 \\
\hline \multicolumn{7}{|l|}{ Consolidated expenditures $3 /$} \\
\hline Current & 9.6 & 9.9 & 12.7 & 14.3 & 14.8 & 16.0 \\
\hline Capital & 2.3 & 3.1 & 3.1 & 5.6 & 5.4 & 7.2 \\
\hline Primary domestic balance (non-oil) 4/ & -4.7 & -4.3 & -4.6 & -6.3 & -6.6 & -10.1 \\
\hline Nominal GDP (SDD bn; at factor cost) & 3,376 & 3,876 & 4,425 & 5,024 & 5,138 & 5,973 \\
\hline
\end{tabular}

1/ Repayments for oil projects for 2003 and 2004 hitherto classified as capital participation in refirnery have been reclassified as principal repayments under net foreign financing.

2/ Total revenue less crude oil revenue.

3/ To facilitate comparison with previous years, it is assumed that one-half of the transfers to the south in 2005 are for capital expenditures.

4/ Define as percent of non-oil GDP. 
Table 6. Sudan: Monetary Survey, 2002-05

(In billions of Sudanese dinars)

\begin{tabular}{|c|c|c|c|c|c|c|c|c|}
\hline & \multirow{3}{*}{$\frac{2002}{\text { Dec. }}$} & \multirow{3}{*}{$\frac{2003}{\text { Dec. }}$} & \multicolumn{2}{|c|}{2004} & \multicolumn{4}{|c|}{2005} \\
\hline & & & \multirow[t]{2}{*}{ Sept. } & \multirow[t]{2}{*}{ Dec. } & Mar. & Jun. & Sept. & Dec. \\
\hline & & & & & \multicolumn{4}{|c|}{ Prog. } \\
\hline Net foreign assets & -627.0 & -570.0 & -387.8 & -341.7 & -312.7 & -279.5 & -248.5 & -202.4 \\
\hline Bank of Sudan & -741.2 & -685.4 & -515.6 & -464.8 & -444.8 & -411.5 & -386.5 & -346.5 \\
\hline Commercial banks & 114.2 & 115.5 & 127.9 & 123.1 & 132.1 & 132.1 & 138.1 & 144.1 \\
\hline Counterpart to valuation changes $1 /$ & 796.8 & 817.0 & 806.2 & 792.1 & 790.6 & 789.1 & 787.6 & 787.6 \\
\hline Net foreign assets (excluding valuation adjustment) & 169.9 & 247.1 & 418.4 & 449.6 & 477.1 & 508.8 & 538.3 & 584.4 \\
\hline Net domestic assets & 292.8 & 487.0 & 462.3 & 510.5 & 561.9 & 579.3 & 615.1 & 643.7 \\
\hline Net domestic credit & 329.7 & 423.8 & 420.3 & 484.4 & 478.2 & 495.3 & 516.8 & 584.9 \\
\hline Net claims on central government & 130.8 & 111.7 & 32.1 & 32.5 & 25.0 & 21.6 & 16.0 & 4.0 \\
\hline Bank of Sudan & 115.0 & 83.1 & 0.0 & -2.8 & -19.2 & -31.4 & -45.8 & -64.9 \\
\hline Claims & 142.2 & 147.9 & 155.8 & 148.7 & 150.2 & 152.3 & 155.0 & 158.7 \\
\hline Deposits & 27.3 & 64.8 & 155.8 & 151.5 & 169.4 & 183.7 & 200.8 & 223.6 \\
\hline Of which: Oil Saving Account & 10.1 & 45.2 & 109.8 & 129.0 & 147.4 & 161.7 & 178.8 & 201.6 \\
\hline Commercial banks & 15.8 & 28.6 & 32.1 & 35.3 & 43.2 & 52.0 & 60.8 & 68.9 \\
\hline Claims on nongovernment sectors & 198.9 & 312.1 & 388.2 & 451.9 & 453.3 & 473.7 & 500.8 & 580.9 \\
\hline Other items (net) & 63.1 & 63.2 & 42.0 & 26.2 & 83.7 & 84.1 & 98.3 & 59.8 \\
\hline Broad money & 563.3 & 734.1 & 880.7 & 960.4 & $1,039.3$ & $1,088.5$ & $1,153.8$ & $1,229.4$ \\
\hline Currency outside banks & 193.6 & 240.2 & 265.1 & 304.9 & 343.0 & 359.2 & 380.7 & 405.7 \\
\hline Deposits & 369.7 & 493.9 & 615.6 & 655.5 & 696.3 & 729.3 & 773.0 & 823.7 \\
\hline \multicolumn{9}{|l|}{ Memorandum items: } \\
\hline Reserve money (in billions of Sudanese dinars) & 280.3 & 354.8 & 413.5 & 453.3 & 494.9 & 518.3 & 549.4 & 585.4 \\
\hline Reserve money (annual percentage change) & 22.0 & 26.6 & 24.5 & 27.8 & 30.2 & 32.9 & 32.9 & 29.1 \\
\hline Broad money (annual percentage change) & 30.3 & 30.3 & 32.0 & 30.8 & 28.9 & 29.7 & 31.0 & 28.0 \\
\hline Credit to nongovernment sector (annual percentage change) & 28.5 & 56.9 & 46.0 & 44.8 & 29.6 & 24.6 & 29.0 & 28.5 \\
\hline Currency to broad money (in percent) & 34.4 & 32.7 & 30.1 & 31.7 & 33.0 & 33.0 & 33.0 & 33.0 \\
\hline Currency to dinar broad money (in percent) & 46.4 & 43.6 & 42.1 & 44.5 & 44.8 & 44.8 & 44.8 & 44.8 \\
\hline Excess reserves to reserve money (in percent) & 14.2 & 12.6 & 15.5 & 15.6 & 14.0 & 14.2 & 14.4 & 14.7 \\
\hline Excess reserves to broad money (in percent) & 7.1 & 6.1 & 7.3 & 7.4 & 6.6 & 6.7 & 6.9 & 7.0 \\
\hline Foreign currency deposits to total deposits (in percent) & 39.6 & 37.2 & 38.7 & 37.7 & 39.3 & 39.3 & 39.3 & 39.3 \\
\hline Broad money multiplier & 2.0 & 2.1 & 2.1 & 2.1 & 2.1 & 2.1 & 2.1 & 2.1 \\
\hline Velocity (average) & 7.6 & 6.9 & & 5.3 & & & $\ldots$ & 4.9 \\
\hline Usable international reserves to broad money (in percent) & 11.6 & 18.8 & 31.5 & 36.8 & 36.0 & 36.8 & 37.1 & 35.7 \\
\hline Usable international reserves (in million of U.S. dollars) & 249 & 527 & 1,046 & 1,334 & 1,414 & 1,514 & 1,614 & 1,754 \\
\hline
\end{tabular}

Sources: Sudanese authorities; and Fund staff estimates.

$1 /$ In 2005, calculated using the exchange rate projected for end-December (program exchange rate). 
Table 7. Sudan: Monetary Authorities'Accounts, 2002-05

(In billions of Sudanese dinars)

\begin{tabular}{|c|c|c|c|c|c|c|c|c|}
\hline & \multirow{3}{*}{$\frac{2002}{\text { Dec. }}$} & \multirow{3}{*}{$\frac{2003}{\text { Dec. }}$} & \multicolumn{2}{|c|}{2004} & \multicolumn{4}{|c|}{2005} \\
\hline & & & \multirow[t]{2}{*}{ Sep. } & \multirow[t]{2}{*}{$\overline{\text { Dec. }}$} & Mar. & Jun. & Sept. & Dec. \\
\hline & & & & & \multicolumn{4}{|c|}{ Prog. } \\
\hline Net foreign assets & -741.2 & -685.4 & -515.6 & -464.8 & -444.8 & -411.5 & -386.5 & -346.5 \\
\hline Foreign assets & 119.8 & 229.7 & 360.5 & 420.4 & 440.4 & 469.2 & 494.2 & 529.2 \\
\hline Foreign liabilities & 861.0 & 915.2 & 876.1 & 885.1 & 885.1 & 880.7 & 880.7 & 875.7 \\
\hline Counterpart to valuation changes 1 / & 796.1 & 816.6 & 804.1 & 788.6 & 789.7 & 788.5 & 786.7 & 788.1 \\
\hline Net domestic assets & 225.3 & 223.7 & 125.1 & 129.5 & 150.0 & 141.3 & 149.2 & 143.8 \\
\hline Net domestic credit & 137.1 & 131.2 & 51.7 & 42.6 & 34.3 & 25.7 & 19.3 & 13.8 \\
\hline Net claims on central government & 115.0 & 83.1 & 0.0 & -2.8 & -19.2 & -31.4 & -45.8 & -64.9 \\
\hline Claims & 142.2 & 147.9 & 155.8 & 148.7 & 150.2 & 152.3 & 155.0 & 158.7 \\
\hline Temporary advances & 30.9 & 37.5 & 37.5 & 37.5 & 35.0 & 32.5 & 30.0 & 27.5 \\
\hline Gov't. securities & 3.9 & 2.9 & 10.9 & 3.8 & 7.8 & 12.4 & 17.6 & 23.8 \\
\hline Long-term claims & 107.5 & 107.5 & 107.5 & 107.5 & 107.5 & 107.5 & 107.5 & 107.5 \\
\hline Deposits & 27.3 & 64.8 & 155.8 & 151.5 & 169.4 & 183.7 & 200.8 & 223.6 \\
\hline Of which: Oil Stabilization Account & 10.1 & 45.2 & 109.8 & 129.0 & 147.4 & 161.7 & 178.8 & 201.6 \\
\hline Other deposits & 17.2 & 19.6 & 46.0 & 22.6 & 22.0 & 22.0 & 22.0 & 22.0 \\
\hline Claims on public enterprises & 5.7 & 17.3 & 18.5 & 15.5 & 17.5 & 17.5 & 17.5 & 17.5 \\
\hline Claims on banks & 17.1 & 33.5 & 32.3 & 30.0 & 36.0 & 39.5 & 47.5 & 61.2 \\
\hline $\begin{array}{l}\text { Money market instruments } \\
\text { (Central Bank Musharaka Certificates) }\end{array}$ & -0.8 & -2.8 & 0.8 & 0.0 & 0.0 & 0.0 & 0.0 & 0.0 \\
\hline Other items (net) & 88.2 & 92.5 & 73.4 & 86.9 & 115.2 & 115.2 & 129.5 & 130.0 \\
\hline Reserve money & 280.3 & 354.8 & 413.5 & 453.3 & 494.9 & 518.3 & 549.4 & 585.4 \\
\hline Currency outside banks & 193.6 & 240.2 & 265.1 & 304.9 & 343.0 & 359.2 & 380.7 & 405.7 \\
\hline Reserves of commercial banks & 75.0 & 87.2 & 117.3 & 128.2 & 128.9 & 136.1 & 145.7 & 156.7 \\
\hline Required reserves $1 /$ & 35.2 & 42.5 & 53.3 & 57.5 & 59.9 & 62.7 & 66.5 & 70.8 \\
\hline Excess reserves & 39.8 & 44.7 & 63.9 & 70.7 & 69.1 & 73.4 & 79.2 & 85.9 \\
\hline Deposits at BOS included in broad money & 11.7 & 27.4 & 31.2 & 20.2 & 23.0 & 23.0 & 23.0 & 23.0 \\
\hline
\end{tabular}

Sources: Sudanese authorities; and Fund staff estimates.

1/ In 2005 calculated of the program exchange rate. 
Table 8. Sudan: Medium-Term Macroeconomic Scenario, 2004-10

\begin{tabular}{|c|c|c|c|c|c|c|c|}
\hline & \multirow{2}{*}{$\frac{\text { Est. }}{2004}$} & \multicolumn{6}{|c|}{ Projections } \\
\hline & & 2005 & 2006 & 2007 & 2008 & 2009 & 2010 \\
\hline \multicolumn{8}{|l|}{ Production and prices } \\
\hline Nominal GDP (billions of Sudanese dinars) & 5,138 & 5,973 & 6,843 & 7,841 & 8,893 & 10,035 & 11,432 \\
\hline Real GDP & 7.3 & 8.3 & 8.6 & 8.6 & 8.8 & 8.5 & 8.5 \\
\hline Non-oil & 6.0 & 5.6 & 6.2 & 7.6 & 8.5 & 9.0 & 9.5 \\
\hline Oil & 21.2 & 30.1 & 16.4 & 13.8 & 10.3 & 5.1 & 4.1 \\
\hline Inflation (period average) & 8.4 & 7.5 & 7.0 & 6.5 & 6.0 & 5.0 & 5.0 \\
\hline \multicolumn{8}{|l|}{ Investment and saving $1 /$} \\
\hline Gross domestic investment & 22.6 & 24.4 & 26.1 & 26.6 & 26.9 & 27.0 & 26.6 \\
\hline Government & 5.1 & 6.8 & 8.1 & 8.4 & 8.6 & 8.6 & 8.1 \\
\hline Nongovernment & 17.5 & 17.7 & 18.0 & 18.2 & 18.3 & 18.4 & 18.5 \\
\hline Gross domestic saving & 18.5 & 20.3 & 22.9 & 23.0 & 22.9 & 22.5 & 22.1 \\
\hline Government & 7.7 & 7.2 & 8.6 & 7.9 & 8.2 & 7.8 & 8.2 \\
\hline Nongovernment & 10.8 & 13.1 & 14.3 & 15.1 & 14.7 & 14.6 & 13.9 \\
\hline Net exports of goods and nonfactor services & -4.0 & -4.1 & -3.3 & -3.7 & -4.0 & -4.6 & -4.6 \\
\hline \multicolumn{8}{|l|}{ Central government operations } \\
\hline Total revenue & 21.5 & 22.6 & 25.4 & 24.8 & 25.2 & 25.0 & 24.6 \\
\hline Oil revenue $2 /$ & 11.2 & 13.0 & 15.9 & 14.7 & 14.6 & 13.6 & 12.7 \\
\hline Non-oil revenue & 10.3 & 9.5 & 9.6 & 10.0 & 10.6 & 11.3 & 12.0 \\
\hline Total expenditure & 20.2 & 23.2 & 25.5 & 25.9 & 26.2 & 26.3 & 25.1 \\
\hline Current expenditures & 14.8 & 16.0 & 16.9 & 16.9 & 17.1 & 17.1 & 16.5 \\
\hline Capital expenditure & 5.4 & 7.2 & 8.6 & 9.0 & 9.1 & 9.2 & 8.5 \\
\hline Overall deficit (cash basis) & 1.3 & -0.6 & -0.1 & -1.2 & -1.0 & -1.4 & -0.4 \\
\hline \multicolumn{8}{|l|}{ External sector } \\
\hline External trade balance & 1.0 & 1.1 & 2.4 & 1.9 & 1.2 & 0.1 & -0.2 \\
\hline Exports & 19.0 & 20.8 & 23.4 & 22.4 & 21.3 & 19.5 & 18.0 \\
\hline Imports & -18.0 & -19.7 & -21.0 & -20.5 & -20.0 & -19.3 & -18.2 \\
\hline Current account balance on cash basis (in percent of GDP) & -4.1 & -5.9 & -6.1 & -6.3 & -6.2 & -6.2 & -6.0 \\
\hline Capital/financial account balance (US\$millions) & 1,308 & 1,462 & 1,558 & 1,617 & 1,661 & 1,735 & 1,852 \\
\hline Gross official reserves (months of imports) & 2.9 & 3.2 & 3.8 & 4.2 & 4.4 & 4.5 & 4.5 \\
\hline Export volume (change in percent) $3 /$ & 14.8 & 7.1 & 9.1 & 9.2 & 10.2 & 10.6 & 10.8 \\
\hline Import volume (change in percent) $3 /$ & 35.1 & 30.8 & 22.9 & 12.5 & 10.5 & 8.4 & 6.3 \\
\hline Terms of trade (change in percent) $3 /$ & 18.2 & 1.9 & -0.4 & -0.4 & -1.3 & 2.1 & 1.2 \\
\hline \multicolumn{8}{|l|}{ Memorandum items: } \\
\hline Sudanese crude oil export price (U.S. dollars per barrel) & 36.4 & 34.0 & 35.0 & 33.0 & 33.0 & 32.0 & 32.0 \\
\hline
\end{tabular}

Sources: Projections based on information provided by the Sudanese authorities; and Fund staff estimates.

1/ In percent of GDP at market prices.

2/ Crude oil revenue.

3/ Non-oil transactions. 
Table 9. Sudan: Indicators of Debt Service Capacity, 2002-05

(In millions of U.S. dollars; unless otherwise indicated)

\begin{tabular}{|c|c|c|c|c|}
\hline & $\frac{\text { Actual }}{2002}$ & $\frac{\text { Actual }}{2003}$ & $\frac{\text { Est. }}{2004}$ & $\frac{\text { Proj. }}{2005}$ \\
\hline Total debt service paid & 137 & 247 & 304 & 361 \\
\hline Payments to the Fund & 26 & 28 & 32 & 30 \\
\hline Charges and interest falling due & 17 & 14 & 17 & 18 \\
\hline Charges settled & 3 & 1 & 2 & 2 \\
\hline Reduction in overdue obligations & 23 & 26 & 30 & 28 \\
\hline Overdue obligations to the Fund & 1,475 & 1,595 & 1,577 & 1,607 \\
\hline Overdue obligations to the Fund (in millions of SDRs) & 1,085 & 1,074 & 1,065 & 1,050 \\
\hline \multicolumn{5}{|l|}{ Total debt service paid, in percent of: } \\
\hline Exports of goods and nonfactor services & 6.8 & 9.5 & 7.9 & 7.2 \\
\hline Net current receipts $1 /$ & 14.4 & 16.7 & 12.9 & 12.1 \\
\hline Gross official reserves & 55 & 47 & 23 & 21 \\
\hline GDP & 0.9 & 1.5 & 1.5 & 1.5 \\
\hline \multicolumn{5}{|l|}{ Payments to the Fund, in percent of: } \\
\hline Exports of goods and nonfactor services & 1.3 & 1.1 & 0.8 & 0.6 \\
\hline Net current receipts $1 /$ & 2.7 & 1.9 & 1.4 & 1.0 \\
\hline Gross official reserves & 10.3 & 5.3 & 2.4 & 1.7 \\
\hline GDP & 0.2 & 0.2 & 0.2 & 0.1 \\
\hline Quota 2/ & 11.1 & 11.0 & 12.9 & 11.6 \\
\hline External debt service & 18.8 & 11.2 & 10.7 & 8.3 \\
\hline \multicolumn{5}{|l|}{ Overdue obligations to the Fund, in percent of: } \\
\hline Exports of goods and nonfactor services & 74 & 61 & 41 & 32 \\
\hline Net current receipts $1 /$ & 155 & 108 & 67 & 54 \\
\hline Gross official reserves & 593 & 303 & 118 & 92 \\
\hline GDP & 10.0 & 9.4 & 7.9 & 6.7 \\
\hline Quota 2/ & 639 & 633 & 628 & 619 \\
\hline External debt & 6.2 & 6.2 & 6.0 & 6.1 \\
\hline \multicolumn{5}{|l|}{ Memorandum items: } \\
\hline Exports of goods and services & 1,996 & 2,613 & 3,822 & 5,022 \\
\hline Net current receipts $1 /$ & 952 & 1,478 & 2,351 & 2,990 \\
\hline Gross official reserves & 249 & 527 & 1,334 & 1,754 \\
\hline In months of next year's imports & 1.0 & 1.5 & 2.9 & 3.2 \\
\hline GDP (in millions of U.S. dollars) & 14,720 & 16,957 & 19,913 & 23,891 \\
\hline Quota (in millions of SDRs) 2/ & 169.7 & 169.7 & 169.7 & 169.7 \\
\hline External debt (including arrears) & 23,609 & 25,709 & 26,201 & 26,506 \\
\hline Exchange rate (U.S. dollar/ SDR, end of period) & 1.36 & 1.49 & 1.48 & 1.53 \\
\hline
\end{tabular}

Source: Fund staff estimates.

1/ Exports of goods and services adjusted for oil related payments for services and transfers to foreign investors.

2/ As percent of Eigth Review Quota. 
Table 10. Sudan: External Financing Requirements and Sources, 2003-05

(Cash basis; in millions of U.S. dollars)

\begin{tabular}{|c|c|c|c|c|}
\hline & $\frac{\text { Actual }}{\underline{2003}}$ & $\begin{array}{l}\text { Prog. } \\
\underline{2004}\end{array}$ & $\begin{array}{r}\text { Est. } \\
2004 \\
\end{array}$ & $\begin{array}{l}\text { Proj. } \\
\underline{2005}\end{array}$ \\
\hline Gross financing requirements & -1288 & -1559 & -1819 & -2152 \\
\hline \multicolumn{5}{|l|}{ External current account deficit } \\
\hline (excluding interest payments and official transfers) $1 /$ & -777 & -994 & -760 & $-1,364$ \\
\hline Debt service payments (interest and principal) & -219.3 & -266.8 & -271.2 & -331.0 \\
\hline Medium- and long-term debt & -219.3 & -266.8 & -271.2 & -331.0 \\
\hline Public sector & -219.3 & -266.8 & -271.2 & -331.0 \\
\hline Multilateral 2/ & -59.9 & -62.6 & -65.8 & -65.7 \\
\hline Paris Club bilaterals & 0.0 & 0.0 & 0.0 & 0.0 \\
\hline Non-Paris Club Bilaterals & -159.4 & -204.2 & -204.4 & -265.3 \\
\hline Gross reserves accumulation & -278 & -280 & -767 & -444 \\
\hline IMF repurchases and repayments & -13 & -18 & -20 & -12 \\
\hline Payments to the Fund & -28 & -30 & -32 & -30 \\
\hline Change in arrears on charges & 14 & 12 & 12 & 18 \\
\hline Expected financing & 1,287 & 1,559 & 1,819 & 1,787 \\
\hline Official transfers and grants & 10 & 60 & 28 & 34 \\
\hline Debt financing & 85 & 370 & 191 & 290 \\
\hline Of which: Merowe project & 55 & 200 & 138 & 200 \\
\hline Multilateral & 37 & 155 & 74 & 135 \\
\hline Bilateral & 48 & 215 & 117 & 155 \\
\hline Foreign direct investment, and errors and omissions & 1,203 & 1,136 & 1,684 & 1,496 \\
\hline IMF purchases and disbursements & 0 & 0 & 0 & 0 \\
\hline Other flows 3 / & -10 & -7 & -85 & -34 \\
\hline Financing gap & 0 & 0 & 0 & 365 \\
\hline
\end{tabular}

Source: Fund staff.

1/ Includes oil sector profit remittances.

2/ Excluding the IMF.

3/ Includes all other net financial flows. 
Table 11. Sudan: Millennium Development Goals, 1990-2002

\begin{tabular}{|c|c|c|c|c|}
\hline & 1990 & 1995 & 2001 & 2002 \\
\hline \multicolumn{5}{|l|}{ 1. Eradicate extreme poverty and hunger } \\
\hline Population below $\$ 1$ a day (in percent) & $\ldots$ & $\ldots$ & $\ldots$ & $\ldots$ \\
\hline Poverty gap ratio at $\$ 1$ a day (in percent) & $\ldots$ & $\ldots$ & $\ldots$ & $\ldots$ \\
\hline Percentage share of income or consumption held by poorest 20 percent & $\ldots$ & $\ldots$ & $\ldots$ & $\ldots$ \\
\hline Prevalence of child malnutrition (percent of children under 5) & $\ldots$ & 33.9 & 11.0 & $\ldots$ \\
\hline Population below minimum level of dietary energy consumption & 31.0 & 22.0 & 25.0 & \\
\hline \multicolumn{5}{|l|}{ 2. Achieve universal primary education } \\
\hline Net primary enrollment ratio (percent of relevant age group) & $\ldots$ & $\ldots$ & 45.8 & $\ldots$ \\
\hline Percentage of cohort reaching grade 5 (percent) & 93.7 & 74.2 & $\ldots$ & $\ldots$ \\
\hline Youth literacy rate (percent ages $15-24$ ) & 65.0 & 71.5 & 78.1 & 79.1 \\
\hline \multicolumn{5}{|l|}{ 3. Promote gender equality } \\
\hline Ratio of girls to boys in primary and secondary education (in percent) & 75.9 & 84.2 & 86.2 & \\
\hline Ratio of young literate females to males (percent ages $15-24$ ) & 71.5 & 79.7 & 87.4 & 88.5 \\
\hline Share of women employed in the nonagricultural sector (in percent) & 22.2 & $\ldots$ & $\ldots$ & $\ldots$ \\
\hline Proportion of seats held by women in national parliament (in percent) & $\ldots$ & 8.0 & $\ldots$ & $\ldots$ \\
\hline \multicolumn{5}{|l|}{ 4. Reduce child mortality } \\
\hline Under 5 mortality rate (per 1,000 ) & 120.0 & 106.0 & 97.0 & 94.0 \\
\hline Infant mortality rate (per 1,000 live births) & 74.0 & 69.0 & 65.0 & 64.0 \\
\hline Immunization, measles (percent of children under 12 months) & 57.0 & 51.0 & 67.0 & 49.0 \\
\hline \multicolumn{5}{|l|}{ 5. Improve maternal health } \\
\hline Maternal mortality ratio (modeled estimate, per 100,000 live births) & $\ldots$ & $\ldots$ & 590.0 & $\ldots$ \\
\hline Births attended by skilled health staff (percent of total) & 69.4 & 86.3 & $\ldots$ & $\ldots$ \\
\hline \multicolumn{5}{|l|}{ 6. Combat HIV/AIDS, malaria, and other diseases } \\
\hline Prevalence of HIV, female (in percent, ages 15-49) & $\ldots$ & $\ldots$ & 3.1 & $\ldots$ \\
\hline Contraceptive prevalence rate (percentage of women ages 15-49) & 8.7 & 10.0 & $\ldots$ & $\ldots$ \\
\hline Number of children orphaned by HIV/AIDS & $\ldots$ & $\ldots$ & 62,000 & $\ldots$ \\
\hline Tuberculosis prevalence rate (per 100,000 people) & $\ldots$ & $\ldots$ & 188.0 & 216.6 \\
\hline Tuberculosis cases detected under DOTS & $\ldots$ & 2.0 & 35.0 & 32.9 \\
\hline \multicolumn{5}{|l|}{ 7. Ensure environmental sustainability } \\
\hline Forest area (percent of total land area) & 30.0 & $\ldots$ & 25.9 & $\ldots$ \\
\hline Nationally protected areas (percent of total land area) & $\ldots$ & 3.6 & 3.6 & 5.2 \\
\hline GDP per unit of energy use (PPP \$ per kg oil equivalent) & 2.3 & 3.5 & 4.3 & $\ldots$ \\
\hline $\mathrm{CO} 2$ emissions (metric tons per capita) & 0.1 & 0.1 & 0.2 & $\ldots$ \\
\hline Access to an improved water source (percent of population) & 67.0 & $\ldots$ & 75.0 & $\ldots$ \\
\hline Access to improved sanitation (percent of population) & 58.0 & $\ldots$ & 62.0 & $\ldots$ \\
\hline Access to secure tenure (percent of population) & $\ldots$ & $\ldots$ & $\ldots$ & $\ldots$ \\
\hline \multicolumn{5}{|l|}{ 8. Develop a Global Partnership for Development } \\
\hline Youth unemployment rate (percent of total labor force ages 15-24) & $\ldots$ & $\ldots$ & $\ldots$ & $\ldots$ \\
\hline Fixed line and mobile telephones (per 1,000 people) & 2.5 & 2.8 & 17.5 & 26.5 \\
\hline Personal computers (per 1,000 people) & $\ldots$ & 0.4 & 3.6 & 6.1 \\
\hline \multicolumn{5}{|l|}{ General indicators } \\
\hline Adult literacy rate (percent of people ages 15 and over) & 45.8 & 51.5 & 58.8 & 59.9 \\
\hline Total fertility rate (births per woman) & 5.4 & 5.1 & 4.6 & 4.4 \\
\hline Life expectancy at birth (years) & 52.2 & 54.9 & 57.5 & 58.4 \\
\hline Aid (percent of GNI) & 6.6 & 3.9 & 1.7 & 2.7 \\
\hline
\end{tabular}

Sources: World Bank, World Development Indicators, and Sudan Country Profile. 


\section{Sudan: Relations With The Fund \\ As of January 31, 2005}

I. Membership Status: Joined 09/05/57; Article VIII ${ }^{28}$

II. General Resources Account:

Quota

Fund holdings of currency

Reserve position in Fund

III. SDR Department:

Net cumulative allocation

Holdings

IV. Outstanding Purchases and Loans:

Stand-by Arrangements

Extended Arrangements

Contingency and Compensatory

Financing Facility

Trust Fund

\begin{tabular}{crr} 
SDR Million & & \% Quota \\
\hline 169.70 & & 100.00 \\
490.72 & & 289.17 \\
0.01 & & 0.01
\end{tabular}

$\underline{\text { SDR Million }}$

52.19

0.29

\begin{tabular}{r} 
SDR Million \\
\hline 183.53 \\
113.02 \\
24.44 \\
59.23
\end{tabular}

$\frac{\% \text { Allocation }}{100.00}$
0.56

$\underline{\% \text { Quota }}$

1108.15

66.60

14.40

34.90

\section{Financial Arrangements:}

\begin{tabular}{|c|c|c|c|c|}
\hline Type & $\begin{array}{c}\text { Approval } \\
\text { Date }\end{array}$ & $\begin{array}{l}\text { Expiration } \\
\text { Date }\end{array}$ & $\begin{array}{c}\text { Amount } \\
\text { Approved } \\
\text { (SDR million) }\end{array}$ & $\begin{array}{c}\text { Amount } \\
\text { Drawn } \\
\text { (SDR million) }\end{array}$ \\
\hline$\overline{\text { Stand }}-b y$ & $06 / 25 / 1984$ & $0 \overline{06 / 24 / 1985}$ & 90.00 & 20.00 \\
\hline Stand-by & $02 / 23 / 1983$ & 03/09/1984 & 170.00 & 170.00 \\
\hline Stand-by & $02 / 22 / 1982$ & $02 / 21 / 1983$ & 198.00 & 70.00 \\
\hline
\end{tabular}

VI. Projected Obligations to the Fund: (SDR million; based on existing use of resources and present holdings of SDRs):

\begin{tabular}{|c|c|c|c|c|c|c|}
\hline & \multirow[t]{2}{*}{ Overdue $^{29} \underline{1 / 31 / 05}$} & \multicolumn{5}{|c|}{ Forthcoming } \\
\hline & & $\underline{2005}$ & $\underline{2006}$ & 2007 & $\underline{2008}$ & $\underline{2009}$ \\
\hline Principal & 380.22 & & & & & \\
\hline Charges/Interest & $\underline{680.44}$ & $\underline{11.77}$ & $\underline{11.86}$ & $\underline{11.86}$ & $\underline{11.87}$ & $\underline{11.85}$ \\
\hline Total & $1,060.67$ & 11.77 & 11.86 & 11.86 & 11.87 & 11.85 \\
\hline
\end{tabular}

\footnotetext{
${ }^{28}$ The staff is in the process of assessing Sudan's compliance with Article VIII obligations.

${ }^{29}$ The projection of charges and interest assumes that overdue principal at the report date (if any) will remain outstanding, but forthcoming obligations will be settled on time.
} 


\section{Exchange Rate Arrangements}

The legal tender is the Sudanese dinar, which replaced the Sudanese pound in proportion

SDD 1=LSd 10 in 1999. Since October 1998, the exchange rate system has been unified-market participants determine the exchange rate and trade freely within a unified regulatory framework. In 2001, the foreign exchange market came under pressure and the Bank of Sudan (BOS), in an effort to increase the flexibility of the system, introduced a formal band of \pm 1.5 percent (later broadened to 2 percent) around the official rate and began auctioning its foreign exchange within the band. In May 2003, the BOS formally adopted a managed-float exchange rate regime. The formal exchange rate band was abandoned and the auction system was replaced with direct transactions in the interbank market. The BOS established an internal limit of \pm 2 percent intraday fluctuations around the average daily market rate that will trigger its intervention. In 2004, the BOS changed the permissible intraday exchange rate fluctuation to \pm 3 percentage points. Sudan maintains one inoperative bilateral payments agreement with Egypt and an inoperative payment clearing account with the former Soviet Union.

\section{Article IV Consultation}

Sudan is on a 12-month consultation cycle. The last Article IV consultation discussion was held from August 16-28, 2003. The Staff Report was discussed by the Executive Board on October 31, 2003.

\section{FSAP Participation}

An FSAP mission took place in October 9-14, 2004 and a follow up mission overlapped with the 2005 Article IV consultation mission in December 1-20, 2004.

\section{Resident Representative}

The Fund's resident representative in Khartoum was withdrawn in June 1990.

\section{Technical Assistance}

In January 1995, the Executive Board decided to resume Fund selective technical assistance to Sudan. A summary of the technical assistance provided is presented in the following table. 
Sudan: Technical Assistance from the Fund, 2000-05

\begin{tabular}{|c|c|c|c|}
\hline Subject & Type of Mission & Timing & Counterpart \\
\hline \multicolumn{4}{|l|}{ Fiscal Affairs Department (FAD) } \\
\hline Reform of indirect taxation & Short-term & Periodic visits in 2000 & $\begin{array}{l}\text { Ministry of Finance } \\
\text { (MOF) }\end{array}$ \\
\hline Expenditure control and management & Short-term & Periodic visits till 2002 & MOF \\
\hline $\begin{array}{l}\text { Reform of direct taxation and revenue } \\
\text { administration }\end{array}$ & Short-term & $\begin{array}{l}\text { November } 2002 \text { and December } \\
2003\end{array}$ & MOF \\
\hline $\begin{array}{l}\text { Reform of direct taxes and investment } \\
\text { incentives }\end{array}$ & Short-term & March, 2003 & MOF \\
\hline Medium-term budgetary framework & Short-term & April, 2003 & MOF \\
\hline Tax and customs administration & Short-term & September, 2003 & MOF \\
\hline $\begin{array}{l}\text { Fiscal cash management and budget } \\
\text { classification }\end{array}$ & Short-term & February 2004 & MOF \\
\hline Fiscal cash management & Short-term & May and September, 2004 & MOF \\
\hline $\begin{array}{l}\text { Revenue administration assessment } \\
\text { (METAC) }\end{array}$ & Short-term & February, 2005 & MOF \\
\hline \multicolumn{4}{|l|}{ Monetary and Financial Department (MFD) } \\
\hline $\begin{array}{l}\text { Monetary management and banking } \\
\text { supervision }\end{array}$ & Short-term & Periodic visits, till 2002 & Bank of Sudan (BOS) \\
\hline Banking supervision & Resident Advisor & May 2001-May 2003 & BOS \\
\hline Islamic compliant monetary instruments & Short-term & October 2002 & BOS \\
\hline $\begin{array}{l}\text { Monetary policy operations and } \\
\text { introduction of a commodities } \\
\text { futures/forward market in the agriculture } \\
\text { sector }\end{array}$ & Short-term & December, 2003 & BOS \\
\hline Monetary policy operations & Short-term & September 2004 & BOS \\
\hline Currency workshop & Short-term & February 2005 & BOS \\
\hline Assess circulating currencies in Sudan & Short-term & March 25-April 1, 2005 & BOS \\
\hline \multicolumn{4}{|l|}{ Statistics Department } \\
\hline Monetary statistics & Short-term & Periodic visits, till 2003 & BOS \\
\hline National accounts and CPI statistics & Short-term & $\begin{array}{l}\text { Periodic visits, March 2002- } \\
\text { February } 2003\end{array}$ & $\begin{array}{l}\text { Central Bureau of } \\
\text { Statistics (CBS) }\end{array}$ \\
\hline Balance of payments statistics & Short-term & July 2003 & BOS \\
\hline General data dissemination system (GDDS) & Short-term & July 2003 & CBS, MFE, and BOS \\
\hline
\end{tabular}




\section{SUDAN: RELATIONS WITH THE WORLD BANK ${ }^{30}$}

(As of April 2, 2005)

The World Bank has no active lending portfolio in Sudan because of Sudan's default on its financial obligations to the Bank, which led to the suspension of disbursements in April 1993. As a result of discussions between the Bank and the Sudanese authorities on the need for Sudan to take steps towards normalizing its relations and establishing a track record with the Bank, the authorities started making "good faith" payments of $\$ 1$ million per month to the Bank starting in July 1999. Monthly payments of an equivalent of $\$ 500,000$ have been made since October 2002. The amount of payments has not been sufficient to prevent a continued accumulation of arrears, which stood at about $\$ 340$ million as of March 31, 2005 (from $\$ 145$ million at the end of 1999). Sudan's outstanding Bank debt, including arrears, is approximately $\$ 1.3$ billion.

The Bank was mostly absent from Sudan between 1992 and 2002. In the 1970s and 1980s, the Bank was a major player in the reconstruction of Sudan, following the Addis Ababa peace agreement of 1972. In the past, the Bank has occasionally supported small initiatives, on a grant basis, such as the UNICEF's data-collection effort. As the prospects for peace rose, the Bank formulated a strategy for re-engaging with Sudan in the event of peace. This strategy, described in the Sudan Country Re-engagement Note (CRN), was discussed by the Executive Board of Directors on July 10, 2003. Main areas of emphasis in the CRN are knowledge generation and sharing; capacity building to support policy reform; demonstration projects to improve delivery of social services; and resolution of the debt overhang.

To rebuild its knowledge base, the Bank completed the first economic report on Sudan in a decade, the Country Economic Memorandum (CEM), which focuses on the social and economic developments in Sudan from the early 1990s to 2002, and the status of macroeconomic, governance, and institutional reforms. The Bank has also engaged the government in policy dialogue on a variety of areas and, together with the Fund, provided technical resource persons for the discussions around wealth sharing in the peace process.

Between January 2004 and March 2005, the Bank co-led (with the UN) a Joint Assessment Mission (JAM), covering eight thematic sectors (institutional development; rule of law; economic policy; productive sectors; basic social services; infrastructure; livelihoods and social protection; and information and media), and several cross-cutting issues, including: gender, environment and conflict. IMF staff participated in a number of workshops and contributed specifically to the economic policy cluster. The JAM synthesis report: "Framework for Transition, Reconstruction and Poverty Eradication"', was completed in March 2005, and outlines the reconstruction and development needs for Sudan over the next six years. ${ }^{31}$ The Report was presented at a Donors' Pledging Conference, held in Oslo on April 11-12, 2005.

\footnotetext{
${ }^{30}$ Prepared by World Bank staff.

${ }^{31}$ The full report can be found on the web at: http://www.unsudanig.org/JAM.
} 
The Wealth Sharing Protocol agreed between the Government of Sudan and the Sudan People's Liberation Movement (SPLM) specified that two Multi-Donor Trust Funds (MDTFs) be established to facilitate the coordination of external donor financing of Sudan's reconstruction and development needs as laid out in the JAM. One fund would be for the new National Government (NG) for war-affected areas in the north and the transition zones, and one for the Government of Southern Sudan (GoSS). The MDTFs would remain operational through the six years of the Interim Period. MDTF-financed activities would be within the context of a unified budget and a coherent public expenditure process. The Implementation Agreement on Wealth Sharing, signed in Naivasha in December 2004, specified that the World Bank would be requested to be the Administrator for both MDTFs, and this was approved by the Board on April 6, 2005.

As part of the JAM, a workshop with the Government and the SPLM initiated work on a joint strategy for poverty eradication (PRSP). IMF staff also participated. During this workshop, the parties reached an agreement on a shared vision for poverty eradication, with an articulation of strategic objectives and associated operational implications. A joint concept note was developed that provides the foundation for a Poverty Eradication Strategy for the new National Government that will be formed.

To support capacity building and policy reform, a US\$4.5 million Low-Income Countries under Stress (LICUS) trust fund grant for Sudan was approved by the LICUS Steering Committee in September 2004. This grant focuses on capacity building and institutional development of fiduciary and aid management systems both in the north and in the south. The trust fund complements two ongoing Post Conflict Fund grants from the World Bank totaling $\$ 3.0$ million.

The Bank participated in two missions to Sudan in October and December 2004 as part of the Financial Sector Assessment Program.

The World Bank is also preparing a Public Expenditure Review (PER), with selected broad activities, which are distinct for the NG and the GoSS. The proposed approach is pragmatic in that a series of distinct activities are being designed to build joint understanding, ownership, and to begin to address capacity building needs over the next two and a half years (through end 2007). IMF staff will participate in this work.

In addition to the above, World Bank staff are working at a technical level with the IMF and other multilateral creditors to explore options for clearance of arrears and debt relief. 


\section{SUDAN: STATISTICAL ISSUES}

Available economic data are sufficient for program monitoring purposes in Sudan. However, there are many areas where further improvements are needed, particularly in compiling national accounts, state budgetary data, and external trade and financial statistics. This appendix discusses outstanding statistical issues by sector.

As a participant in the Department for International Development (DFID) project for Anglophone African countries, Sudan has been receiving technical assistance in various area related to statistical issues. DFID financed three Statistics Department (STA) missions in June-July 2003 (monetary and financial statistics, balance of payments statistics, and the General Data Dissemination System (GDDS) metadata completion), contributing to Sudan's participation in the GDDS starting in August 2003. In early 2004, Sudan also received assistance for the initial stages of preparation of a strategic plan for the Central Bureau of Statistics (CBS).

\section{REAL SECTOR}

Though the compilation and dissemination of the monthly Consumer Price Index (CPI) has been commendable in recent years, the compilation of the national accounts data lags behind. Monthly CPI data for the Khartoum area are provided shortly after the end of each month while the CPI including other states is provided with a three-month lag.

The national accounts statistics suffer from a lack of basic information for many sectors, including oil, livestock, horticulture, and most services. On the expenditure side, data are lacking on final consumption by households, investment, and changes in stocks. There are no national accounts or industrial production data at sub annual frequencies. Furthermore, the annual data are being reported with a lag of over three years. There is an urgent need to rebuild the institutional capacity of the CBS, introduce the 1993 System of National Accounts, conduct a census of agricultural production, and improve coordination among the Ministry of Finance and National Economy (MOFNE), the Ministry of Energy and Mining, the Ministry of Agriculture and Livestock, and the CBS. A peripatetic real sector expert is assisting the authorities in compiling and updating the national accounts.

\section{Fiscal SECTOR}

Government finance statistics reported to MCD are adequate, with the main revenue, expenditure, and financing items reported on a monthly basis with a lag of about one to two months. Financing items are consistent with the monetary accounts. The reported statistics are for the budgetary central government only, and do not include consolidated data for the central government, which are often not available. Data are submitted using economic classification and, while the allocation of resources by MOFNE to the various ministries is reported, their actual expenditures are not. There is a strong need to improve accounting and reporting procedures at MOFNE, introduce the GFS classifications according to guidelines 
provided in Government Finance Statistics Manual (GFSM) 2001, and fully implement the 1997 GFS technical assistance mission's other recommendations. Data reported for the Government Finance Statistics Yearbook are weak and cover only budgetary central government up to 1999. Monthly and quarterly fiscal data are not reported for the International Financial Statistics (IFS).

\section{MONETARY SECTOR}

Sudan has received significant technical assistance resources to improve progressively the collection, compilation, and dissemination of monetary and financial statistics. Following a joint MCD and STA mission in monetary and financial statistics in October 1992, six STA missions were undertaken between 1993 and 2003 to further the development and implementation of the long-term plan of action initiated by the 1992 mission. Consequently, the monetary accounts are broadly acceptable for monitoring purposes; however, STA is concerned that, in the absence of prompt, remedial action as suggested by the July 2003 monetary and financial statistics mission, there may be a re-emergence of the problems of overestimation of international reserves and errors and omissions in the determination of net credit to government. This concern is based on findings that there has been only partial implementation of some of the most important recommendations and that some useful measures that had earlier been fully implemented are now discontinued. For example, balance sheet data of the central bank and commercial banks are reported on a monthly basis and are generally on time. Nevertheless, other items (net) are often large and variable, owing to the grouping of a large volume of transactions into unclassified assets and unclassified liabilities. Moreover, there are frequent classification errors in the reports made by the commercial banks, particularly for consortium financing, which prevents a meaningful analysis of net domestic assets.

The weekly flash reports of the authorities are particularly commendable, with key monetary indicators being reported usually with a one-week lag. Starting January 2003, estimates of the Bank of Sudan's (BOS) usable reserves were added. However, there is some divergence between reserve money in the balance sheets and the end-of-month flash reports.

To address these weaknesses, STA agreed to provide a program of peripatetic assistance. The first of these missions (July 2003) noted limited progress in the BOS's implementation of recommendations of past missions and suggested that significant efforts be made by the authorities to follow up on the highest priority measures, including a revision of the guidelines related to consortium financing and compliance, and the establishment of a working group to review the BOS's foreign assets. A second mission has been postponed to allow further time for the implementation of some of these recommendations.

\section{EXTERNAL SECTOR}

Daily exchange rate data are reported to the Fund with minimal lags, but there are several areas for improvement in the external accounts, particularly with regard to foreign direct 
investment, trade, and oil statistics. The BOS's active balances include unusable reserves earmarked for particular purposes such as medicine, oil, and spare part imports, but the composition of these earmarked reserves and their potential usability in the event of a balance of payment need is not clear. The authorities need to provide clarification on items that qualify as international reserves in general, and those earmarked reserves in particular, and should begin implementing the reserves template.

Regarding import statistics, there are significant discrepancies between the reports of the customs authorities and the BOS. The July 2003 STA mission identified some possible causes of such discrepancies and, in collaboration with authorities, attempted to reconcile the data. The mission reported some progress on implementing the recommendations of the 1999 TA report on balance of payments statistics. However, the lack of survey data continues to affect the compilation of important balance of payments items such as foreign direct investment.

Medium-term oil production projections and amortization of private sector investment need substantial improvement. The authorities have made some progress in improving oil projections, but appear reluctant to provide more detailed information on the phasing-in and expected production levels of new blocks and on amortization of investment in the oil sector. Total oil reserves available are estimated between 10 to 15 billion barrels, which, at a production rate of 350 thousand barrels a day, would last about 100 years. 
Sudan: Data Quality

\begin{tabular}{|c|c|c|c|c|}
\hline $\begin{array}{c}\text { Type of } \\
\text { Data }\end{array}$ & $\begin{array}{l}\text { Scope and } \\
\text { Timeliness of } \\
\text { Reporting }\end{array}$ & $\begin{array}{l}\text { Adequacy for } \\
\text { Monitoring }\end{array}$ & Areas of Concern & Steps to Improve Integrity \\
\hline \multirow[t]{2}{*}{$\begin{array}{l}\text { Real sector: } \\
\text { national } \\
\text { accounts }\end{array}$} & $\begin{array}{l}\text { Historical data } \\
\text { reported on time by } \\
\text { the Central Statistics } \\
\text { Office. }\end{array}$ & $\begin{array}{l}\text { Broadly acceptable: } \\
\text { Real and nominal GDP } \\
\text { by sector available with } \\
\text { a 2-year lag. }\end{array}$ & $\begin{array}{l}1968 \text { System of National Accounts (SNA) still } \\
\text { in use; oil sector value-added calculation not } \\
\text { completed; no real GDP by expenditure; } \\
\text { 4-year delay in nominal GDP by expenditure; } \\
\text { private consumption derived as a residual; } \\
\text { estimations rather than surveys are used for } \\
\text { most GDP components. }\end{array}$ & $\begin{array}{l}\text { Rebuild the Central Bureau of } \\
\text { Statistics' (CBS) institutional capacity; } \\
\text { introduce the } 1993 \text { SNA; conduct } \\
\text { census of agricultural production. } \\
\text { Implement the project prepared by the } \\
\text { STA's peripatetic real sector expert. }\end{array}$ \\
\hline & $\begin{array}{l}\text { Last and current year } \\
\text { estimates reported to } \\
\text { missions by the } \\
\text { ministry of finance } \\
\text { and national } \\
\text { economy (MOFNE). }\end{array}$ & Acceptable. & $\begin{array}{l}\text { Estimates are based on incomplete data, in } \\
\text { particular for oil value added, livestock, and } \\
\text { fruit and vegetable production. }\end{array}$ & $\begin{array}{l}\text { Improve coordination between } \\
\text { MOFNE, CBS, and the ministry of } \\
\text { agriculture. }\end{array}$ \\
\hline Prices & $\begin{array}{l}\text { Monthly CPI } \\
\text { reported on time, } \\
\text { with a minimal lag. }\end{array}$ & $\begin{array}{l}\text { Acceptable; only CPI for } \\
\text { Khartoum area available } \\
\text { promptly; weekly CPI } \\
\text { published in the flash } \\
\text { report. }\end{array}$ & CPI for Sudan as a whole is not available. & $\begin{array}{l}\text { Conduct new household income and } \\
\text { expenditure survey; reduce timing } \\
\text { discrepancies and other reporting } \\
\text { inefficiencies by individual states. }\end{array}$ \\
\hline $\begin{array}{l}\text { Government } \\
\text { finance }\end{array}$ & $\begin{array}{l}\text { Monthly reporting of } \\
\text { main budgetary } \\
\text { items, generally on } \\
\text { time; } 1.5 \text {-month lag. }\end{array}$ & $\begin{array}{l}\text { Good; main revenue and } \\
\text { expenditure items } \\
\text { reported; financing } \\
\text { consistent with monetary } \\
\text { accounts. }\end{array}$ & $\begin{array}{l}\text { Only partial data on state budgets available; } \\
\text { incomplete functional classification; MOFNE } \\
\text { allocations to ministries are reported, but not } \\
\text { their actual expenditure; slow progress on the } \\
\text { introduction of the government finance } \\
\text { statistics (GFS) classification. }\end{array}$ & $\begin{array}{l}\text { Introduce the GFS classification; } \\
\text { improve accounting and reporting } \\
\text { procedures at MOFNE. Implement in } \\
\text { full GFS (1997) technical assistance } \\
\text { (TA) mission recommendations. }\end{array}$ \\
\hline $\begin{array}{l}\text { Monetary } \\
\text { accounts }\end{array}$ & $\begin{array}{l}\text { Monthly reporting of } \\
\text { balance sheets. } \\
\text { Generally on time; } \\
1.5 \text {-month lag. }\end{array}$ & $\begin{array}{l}\text { Acceptable following } \\
\text { recent STA missions to } \\
\text { improve transparency } \\
\text { and reliability of the } \\
\text { monetary statistics. }\end{array}$ & $\begin{array}{l}\text { Large and variable other items (net); frequent } \\
\text { misclassification errors by commercial banks, } \\
\text { in particular for consortium financing, which } \\
\text { prevents meaningful analysis of the } \\
\text { composition of net domestic assets (NDA). }\end{array}$ & $\begin{array}{l}\text { Establish a working group to review the } \\
\text { Bank of Sudan's (BOS) foreign assets; } \\
\text { review and revise the guidelines related } \\
\text { to consortium financing and ensure } \\
\text { compliance. Implement the } 2001 \mathrm{TA} \\
\text { mission on monetary statistics } \\
\text { recommendations, including } \\
\text { improvement of commercial banks' } \\
\text { other items net. }\end{array}$ \\
\hline
\end{tabular}




\begin{tabular}{|c|c|c|c|c|}
\hline \multirow[t]{2}{*}{$\begin{array}{l}\text { Type of } \\
\text { Data }\end{array}$} & $\begin{array}{l}\text { Scope and } \\
\text { Timeliness of } \\
\text { Reporting }\end{array}$ & $\begin{array}{l}\text { Adequacy for } \\
\text { Monitoring }\end{array}$ & Areas of Concern & Steps to Improve Integrity \\
\hline & $\begin{array}{l}\text { Weekly flash reports } \\
\text { of key monetary } \\
\text { aggregates; 1-week } \\
\text { lag. }\end{array}$ & $\begin{array}{l}\text { Good; estimates of } \\
\text { usable reserves of BOS } \\
\text { added in January } 2003 \text {. }\end{array}$ & $\begin{array}{l}\text { Some divergence between reserve money in } \\
\text { balance sheets and end-of-month flash reports. }\end{array}$ & $\begin{array}{l}\text { Include data on returns on investment } \\
\text { deposits. Aim at full reporting of the } \\
\text { BOS balance sheet. }\end{array}$ \\
\hline $\begin{array}{l}\text { External } \\
\text { sector: } \\
\text { foreign } \\
\text { exchange } \\
\text { reserves }\end{array}$ & $\begin{array}{l}\text { Monthly reporting of } \\
\text { BOS active balances. } \\
\text { Generally on time; } \\
0.5 \text {-month lag. }\end{array}$ & $\begin{array}{l}\text { Acceptable, but needs } \\
\text { improvement; frequency } \\
\text { of monitoring should } \\
\text { increase to weekly; } \\
\text { quality of data needs to } \\
\text { be strengthened. }\end{array}$ & $\begin{array}{l}\text { Gross usable reserves are part of BOS active } \\
\text { balances, which also include unusable } \\
\text { reserves earmarked for particular purposes } \\
\text { (such as oil, medicine, and spare parts } \\
\text { imports). The composition of the earmarked } \\
\text { reserves and their potential usability in the } \\
\text { case of a balance of payment need are not } \\
\text { clear. }\end{array}$ & $\begin{array}{l}\text { Clarify the items that qualify as } \\
\text { international reserves in general, and } \\
\text { those included in earmarked reserves in } \\
\text { particular. }\end{array}$ \\
\hline $\begin{array}{l}\text { Exchange } \\
\text { rate }\end{array}$ & $\begin{array}{l}\text { Upon request; } \\
\text { minimal lag. }\end{array}$ & $\begin{array}{l}\text { Good: daily exchange } \\
\text { rate available. }\end{array}$ & & \\
\hline \multirow[t]{2}{*}{$\begin{array}{l}\text { Balance of } \\
\text { payments }\end{array}$} & $\begin{array}{l}\text { Quarterly full BOP } \\
\text { data provided on } \\
\text { time and during } \\
\text { missions; 3-month } \\
\text { lag. }\end{array}$ & $\begin{array}{l}\text { Acceptable, but needs } \\
\text { improvement. }\end{array}$ & $\begin{array}{l}\text { Incompleteness of data on some services (oil } \\
\text { transportation costs), investment income (oil- } \\
\text { related expenses and interest payments due on } \\
\text { external public debt), transfers (workers' } \\
\text { remittances), financial account (amortization } \\
\text { due on external public debt), and FDI; large } \\
\text { positive errors and omissions. }\end{array}$ & $\begin{array}{l}\text { Introduce the revised reports form for } \\
\text { commercial banks; improve data } \\
\text { collection procedures; enforce the use } \\
\text { of residency criterion; enhance } \\
\text { institutional capacity of the BOS BOP } \\
\text { compilation unit. Implement in full the } \\
\text { recommendations of the } 1999 \text { and } 2003 \\
\text { TA in BOP statistics. }\end{array}$ \\
\hline & $\begin{array}{l}\text { Monthly trade data; } \\
\text { upon request } \\
\text { provided with a } \\
2-3 \text { month lag. }\end{array}$ & $\begin{array}{l}\text { Acceptable, but needs } \\
\text { improvement. }\end{array}$ & $\begin{array}{l}\text { Discrepancies between BOS data and customs } \\
\text { data. }\end{array}$ & \\
\hline \multirow[t]{2}{*}{$\begin{array}{l}\text { External } \\
\text { debt }\end{array}$} & $\begin{array}{l}\text { Monthly payments to } \\
\text { creditors. On } \\
\text { time; } 1.5 \text {-month lag. }\end{array}$ & $\begin{array}{l}\text { Good; BOS cash flow } \\
\text { table is not available. }\end{array}$ & $\begin{array}{l}\text { BOS cash flow table does not reflect exactly } \\
\text { actual payments made by the MOFNE. }\end{array}$ & $\begin{array}{l}\text { Eliminate timing and recording } \\
\text { discrepancies between the BOS and the } \\
\text { MOFNE. }\end{array}$ \\
\hline & $\begin{array}{l}\text { Other debt data; } \\
\text { 10-month lag. }\end{array}$ & $\begin{array}{l}\text { Good; coverage is } \\
\text { comprehensive, although } \\
\text { weaknesses in some } \\
\text { areas persist. }\end{array}$ & $\begin{array}{l}\text { BOS records are not reconciled with those of } \\
\text { some creditors; data on Official Development } \\
\text { Assistance not available; charges on interest in } \\
\text { arrears not calculated; for some creditors, } \\
\text { interest on arrears not separated from delayed } \\
\text { interest. }\end{array}$ & $\begin{array}{l}\text { Reconcile the data with creditors; } \\
\text { further disaggregate the data according } \\
\text { to standard definitions; Debt } \\
\text { Management Unit to send monthly } \\
\text { statements on external debt to the } \\
\text { BOS's Statistics Department. }\end{array}$ \\
\hline
\end{tabular}




\section{SUDAN: TABLE OF COMMON INDICATORS REQUIRED FOR SURVEILLANCE}

As OF MARCH 21, 2005

\begin{tabular}{|c|c|c|c|c|c|}
\hline & $\begin{array}{c}\text { Date of latest } \\
\text { observation }\end{array}$ & $\begin{array}{l}\text { Date } \\
\text { received }\end{array}$ & $\begin{array}{c}\text { Frequency } \\
\text { of } \\
\text { Data }^{6}\end{array}$ & $\begin{array}{l}\text { Frequency } \\
\text { of } \\
\text { Reporting }^{6}\end{array}$ & $\begin{array}{l}\text { Frequency of } \\
\text { publication }\end{array}$ \\
\hline Exchange Rates & $3 / 9 / 05$ & $3 / 9 / 05$ & $\mathrm{D}$ & $\mathrm{D}$ & $\mathrm{D}$ \\
\hline $\begin{array}{l}\text { International Reserve Assets and Reserve Liabilities } \\
\text { of the Monetary Authorities } 1\end{array}$ & $1 / 31 / 05$ & $3 / 8 / 05$ & M & M & M \\
\hline Reserve/Base Money & $1 / 31 / 05$ & $3 / 8 / 05$ & M & $\mathrm{W}$ & $\mathrm{M} / \mathrm{W}$ \\
\hline Broad Money & $1 / 31 / 05$ & $3 / 8 / 05$ & $\mathrm{~W}$ & $\mathrm{~W}$ & $\mathrm{M} / \mathrm{W}$ \\
\hline Central Bank Balance Sheet & $1 / 31 / 05$ & $3 / 08 / 05$ & M & M & M \\
\hline Consolidated Balance Sheet of the Banking System & $1 / 31 / 05$ & $3 / 08 / 05$ & M & M & M \\
\hline Interest Rates ${ }^{2}$ & $1 / 31 / 05$ & $3 / 8 / 05$ & $\mathrm{~W}$ & M & $\mathrm{M} / \mathrm{W}$ \\
\hline Consumer Price Index & Dec. 2004 & $2 / 15 / 05$ & $\mathrm{M} / \mathrm{W}$ & M & M \\
\hline $\begin{array}{l}\text { Revenue, Expenditure, Balance and Composition of } \\
\text { Financing }{ }^{3}-\text { General Government }\end{array}$ & Dec. 2004 & $2 / 15 / 05$ & M & M & M \\
\hline $\begin{array}{l}\text { Stocks of Central Government and Central } \\
\text { Government-Guaranteed Debt }\end{array}$ & Dec. 2004 & Feb. 2005 & $\mathrm{~A}$ & $\mathrm{~A}$ & A \\
\hline External Current Account Balance & Q4/2004 & Feb. 2005 & Q & Q & Q \\
\hline Exports and Imports of Goods and Services & Dec. 2004 & Feb. 2005 & M & M & M \\
\hline GDP/GNP & 2003 & Dec. 2004 & A & A & A \\
\hline Gross External Debt & Q4/2004 & Feb. 2005 & A & A & A \\
\hline
\end{tabular}

${ }^{1}$ Includes reserve assets pledged or otherwise encumbered as well as net derivative positions.

${ }^{2}$ Both market-based and officially determined, including discount rates, money market rates, rates on treasury bills, notes and bonds.

${ }^{3}$ Foreign, domestic bank, and domestic non-bank financing.

${ }^{4}$ The general government consists of the central government (budgetary funds, extra budgetary funds, and social security funds) and state and local governments.

${ }^{5}$ Including currency and maturity composition.

${ }^{6}$ Daily (D); Weekly (W); Monthly (M); Monthly/weekly (M/W); Bi-monthly (B); Quarterly (Q); Annually (A); Irregular (I); Not Available (NA) 
Sudan: Tentative Work Program, 2005

Participation in the Oslo Donor Conference

Staff Visit (monitoring of performance, supplementary budget)

Mid-year Review of the 2005 SMP

Staff Visit (2006 Budget)
April 2005

May 2005

August 2005

November 2005 
March 18, 2005

Ms. Anne O. Krueger

Acting Managing Director

International Monetary Fund

Washington, D.C. 20431

Dear Ms. Krueger,

We have carried out with the Fund staff discussions on the successful implementation of the 2004 Staff Monitored Program (SMP) and the Article IV consultation. We have also reached agreement on strong SMP for 2005, which maintains macroeconomic stability, while incorporating the substantial resources needed to meet the peace agreement.

The government believes that the policies set forth in the attached Memorandum of Economic and Financial Policies (MEFP) are adequate to achieve the objectives of the program. In light of the uncertainties surrounding the support from the International Community and oil prices, we may take further measures that may become appropriate for the purpose of implementing the program. Sudan will consult the Fund on adopting revision of the policies contained in the MEFP.

We look forward to the Executive Board's discussion of our performance under the 2004 SMP and endorsement of the strength of our policies under the 2005 SMP. We believe that the policy content of these programs is equal in strength to a Rights Accumulation Program (RAP). We will also redouble our efforts with international creditors to obtain financing assurances for debt relief under the Heavily Indebted Poor Countries (HIPC) framework and allow Sudan to move expeditiously to a RAP. However, in the event that such assurances are delayed, we would like the Fund to explore other options to resolve Sudan's arrears with the IMF in a timely manner to allow the normalization of Sudan's financial relation with its international creditors and the resumption of external assistance

In light of the substantial financing needs for post- peace reconstruction, we propose to maintain the payment to the Fund at the 2004 program level of US\$30 million. We hope that both the Board and management will take into consideration the need to finance new commitments arising from the peace agreement.

Sincerely yours,

$$
/ \mathrm{s} /
$$

Al- Zubeir Ahmed AL-Hassan

Minister of Finance and

National Economy

Ministry of Finance and National Economy
$/ \mathrm{s} /$

Dr. Sabir Mohamed Hassan

Governor

Bank of Sudan

SUDAN 


\section{Memorandum of ECONOMic ANd Financial Policies \\ MARCH 3, 2005}

1. This memorandum reviews the outcome of the 2004 Staff Monitored Program (SMP), outlines the government's economic program for 2005, and sets forth our medium-term policy objectives.

\section{PERFORMANCE UNDER THE 2004 SMP}

2. Policy performance under the 2004 SMP was broadly in line with the program. All quantitative benchmarks were met except the one on the contracting of nonconcessional external debt (Table 1). On the background of lack of access to concessional external resources and urgent development needs, we have decided to contract US\$310 million of nonconcessional debt to finance priority infrastructure projects in the electricity and water sectors. The structural measures scheduled for implementation by end-December 2004 were largely met (Table 2), though there were some delays because of the need to consider the implications of the peace agreement (see below). During 2004, Sudan paid the Fund $\$ 32.4$ million, slightly above the program target.

\section{Recent Macroeconomic ANd Policy Developments}

3. We signed on January 9, 2005, a Comprehensive Peace Agreement (CPA) with the Sudan People's Liberation Movement/Army (SPLM/A), ending 20 years of conflict in south Sudan. The agreements, establishes an autonomous government for Southern Sudan, and provides for broader participation in government and the civil service, the restructuring of critical national institutions, and a new national constitution. The Wealth Sharing Agreement provides a national macroeconomic framework for resource allocation and sustainable decentralization.

4. The Sudanese economy achieved a real GDP growth of about 7.3 percent in 2004, compared to 6.7 percent under the program and 6.0 percent in 2003 , because of stronger-than-expected oil production and continued robust growth in the non-oil sectorparticularly in construction, agriculture, and livestock. Average inflation rose to 8.4 percent in 2004 compared with 6.5 percent under the program and 7.7 percent in 2003 . Reflecting a stronger external position, the exchange rate of the Sudanese dinar against the U.S. dollar appreciated by 3 percent in the second half of 2004. For the year as a whole, the dinar appreciated by 8 percent in real effective terms, following a 4.7 percent depreciation in 2003.

5. The external current account deficit (on cash basis) declined to 4.1 percent of GDP compared to about 5 percent in 2003, owing to both high oil prices and a strong recovery in non-oil exports. Oil exports rose by 50 percent to reach $\$ 3.1$ billion. Non-oil exports also grew strongly by about 37 percent, led by exports of sesame seeds, meat and livestock. Imports also grew by 41 percent with much of the increase coming from a continued rising share of machinery and transport equipments in total imports. Net private transfers and 
foreign direct investment (FDI) flows also grew rapidly reaching $\$ 2.5$ billion. Consequently, gross usable international reserves rose by about US $\$ 807$ million to US\$1.3 billion (2.9 months of the next year's imports).

6. Stronger oil and non-oil revenues and expenditure restraint led to a considerable improvement in the fiscal position in 2004. The budget recorded a surplus of 1.3 percent of GDP in 2004 compared to a deficit of 1.2 percent under the program. Oil revenues rose to 11.3 percent of GDP compared with 9.5 percent in 2003 . Non-oil revenues rose from 8 percent of GDP in 2003 to 10.3 percent in 2004, largely because of recently introduced tax measures and better tax administration, including the establishment of the large taxpayer unit. On the expenditure side, current expenditures were slightly above the program level because of the need to fund internal security and humanitarian relief operations in Darfur and domestic debt repayments. Even though the domestic non-oil (primary) deficit rose in relation to non-oil GDP in 2004, it was only slightly higher than programmed, reflecting strong efforts on non-oil revenues and higher savings in the OSA. The latter accumulated the equivalent of 1.6 percent of GDP (compared to 1.1 percent under the program) despite the use of oil revenues to pay for emergency spending in Darfur.

7. Broad money growth (on an annual basis) decelerated to 30.8 percent by endDecember after rising by 37.3 percent at end-June 2004. Reserve money growth also decelerated to 27.8 percent at end-December compared with 36 percent at end-June 2004, despite a substantial rise in Bank of Sudan's (BOS) net foreign assets and higher government spending. The fall in monetary growth reflected monetary tightening by the BOS in the second half of 2004, primarily through raising the reserve requirement from 12 to 14 percent (in mid-June 2004) and open market sales of government securities and foreign exchange.

8. We made progress in implementing structural reforms. In the fiscal area, a draft reviewing all regulations and agreements that grant tax exemptions has been completed. However, the action plan to streamline regulations in the context of the 2005 budget is still under preparation and will not be applicable until the 2006 budget. A large taxpayers' unit was established in early 2004 and is now operational. We also made progress in improving budget classification and the presentation of fiscal data. New budget classification systems have been approved for further piloting and implementation-economic and functional classifications in line with the Government Finance Statistics (GFS), and the fiscal data for 2001-2003 have been reclassified according to the new classification. Fiscal reports of the budget are now prepared on a monthly basis. We made efforts to improve public expenditure management by setting up a cash management unit at the Ministry of Finance, although we are still facing capacity and coordination problems in making the unit operational. Finally, to strengthen internal controls at the Ministry of Finance, its accounting and audit department has been reconstituted as a general directorate and has been empowered accordingly. 
9. In the monetary area, the steady progress in making the monetary operations unit at the BOS operational has greatly facilitated the management and monitoring of domestic liquidity.

10. To strengthen external debt management, a high-level committee has drafted a new debt strategy and borrowing policy The policy has been approved by the Minister of Finance and due to be submitted to the Council of Ministers in 2005. The strategy emphasizes the use of alternative financing avenues and contracting external debt only rarely and on concessional terms. It identifies three preferred financing options: attracting foreign direct investments, considering build-operate-transfer (BOT) options, and borrowing from the domestic market.

11. In the oil sector, the 2003 accounts of the Sudan Petroleum Corporation (SPC) and many of its subsidiaries have been audited by the Auditor General of Sudan and a summary of the audit report was submitted to parliament.

12. In line with our commitment to increasing the role of the private sector in the economy, we continued to pursue an active program of public sector restructuring and privatization. The restructuring of Sudan Airways has started to prepare it for privatization. In addition, the debts of a number of public sector companies were consolidated (e.g., Public Corporation for Sugar Trade, Rabak Cement Co., National Co. for Water Development, Public Corporation for Irrigation Works, and Atbara Cement Factory). The privatization of Khartoum Bank has advanced, albeit at a slower pace than expected. Because of the costs associated with restructuring and debt consolidation, net privatization receipts were negative, despite gross proceeds of about SDD 10 billion.

\section{OUTLOOK AND POLICIES FOR 2005}

13. We will continue to implement prudent economic policies in 2005 with the aim of maintaining macroeconomic stability and sustaining economic growth while meeting the demands of the implementation of the peace agreement and the expenditures associated with the situation in Darfur. The conduct of economic policy will be challenging, given the complexity of the post-conflict environment and the need to restructure institutions as mandated by the peace agreement. To support the attainment of the policy objective, relevant structural reforms will be implemented or initiated in 2005.

14. The program envisages 8.3 percent real GDP growth, an average inflation rate of 7.5 percent, and an increase in international reserves to about 3.2 months of imports. Oil GDP is projected to grow by about 27 percent, reflecting the coming on stream of new oil fields in the third quarter of 2005. Non-oil real GDP growth is expected to slow to 5.6 percent, largely because of below-average rainfall affecting agricultural output. Construction and transport services are expected to grow strongly, in part related to the initiation of peace-related projects. 
15. On a cash basis, the external current account deficit net of official transfers is expected to worsen to 5.9 percent of GDP. Exports are expected to grow by about 31 percent reflecting the projected increase in oil exports and continued recovery of non-oil exports. However, import demand is also projected to grow rapidly in line with the postconflict needs. We also expect cost-recovery and investment expenses in the oil sector to increase income payments to nonresidents significantly. The current account deficit will be financed, in part, by private capital inflows, some project financing and on-going international humanitarian aid (for south Sudan and Darfur). However, additional donor support of at least $\$ 400$ to $\$ 500$ million will be needed to finance the external current deficit in 2005. In the event that donor support falls short, we expect a slower build up of international reserves, as the room for tightening domestic policies is limited given the needs of peace.

\section{Fiscal}

16. Notwithstanding the high demands of the peace agreement, we remain committed to pursuing prudent fiscal policies, and we aim to contain the domestically financed budget deficit to about 1 percent of GDP. The 2005 budget incorporates the stipulations of the peace protocols, and envisages increased use of oil revenues, expenditure restraint, and domestic borrowing to finance the additional outlays. We note also that the 2005 budget does not include external assistance beyond what Sudan has been receiving in recent years. However, to address poverty issues adequately in the post-conflict environment, we foresee the need for external financial assistance to fund urgent social and development programs. These programs have been detailed in a needs-assessment report that has been prepared by the UN and the World Bank. In the event that additional external funding is secured, a supplementary budget will be submitted to parliament for funding the new program.

17. Fiscal revenues are projected to rise in 2005 by one percentage point of GDP because of higher oil revenues. Given the substantial efforts to raise tax revenues in 2004, imposing new taxes in a year when the peace agreement is about to be implemented will be difficult and thus no new measures are envisaged in the 2005 budget. Furthermore, non-oil revenues are expected to decline by just under 1 percent of GDP, because the excise tax on domestic petroleum products will be lowered in 2005 to offset the higher international oil prices. This will leave domestic oil prices at par with international prices. Nevertheless, we stand ready to phase back the petroleum excise tax or take other measures if fiscal pressures mount.

18. Oil revenues are projected to rise by about 2 percentage points of GDP, reflecting rising oil production. Despite an increase in the oil savings account (OSA) benchmark price to $\$ 30$ per barrel, the OSA is expected to accumulate about 1.2 percent of GDP, assuming the price of oil averages US\$35 per barrel. The saving in the OSA is expected to continue to provide adequate expenditure coverage in the event of an unforeseen drop in international oil prices. 
19. Fiscal spending will rise rapidly in 2005, reflecting peace-related expenditures and our efforts to strengthen Sudan's federal system through greater decentralization. The 2005 budget envisages an increase in federal government transfers to the states (including to the south) from 1.6 percent of GDP in 2004 to about 8.4 percent in 2005, of which, about 4.6 percent of GDP will be allocated to south Sudan for the south's share of oil revenues and the remainder to other states. We plan an across the board expenditure restraint to accommodate these higher transfers. Plans to implement the wage increase have been put on hold and public sector wages are projected to fall slightly in relation to GDP. In anticipation of an improved security environment, we have also reduced the allocations for emergency defense-related spending, as captured under the item "general reserve" in the budget.

20. We envisage a number of structural reforms on the fiscal front. To improve tax administration further, a medium taxpayers' unit will be established by end-June 2005 . The cash management unit will be strengthened along the lines recommended by Fund technical assistance. In addition, we have prepared a two-year plan to move towards a single treasury account. As a first step, a single treasury account for all of Ministry of Finance operations will be set up by mid-2005. A two-year program to adopt economic and functional budget classification system (in line with the 2001 GFS classifications) has also been approved. In 2005 , as a pilot project, we will begin implementation of GFS budget classification in two federal ministries and two states and we will formulate the 2006 budget in line with the GFS classification.

\section{Monetary Policy and Financial System}

21. The program will target a broad money growth rate of 28 percent in 2005 , consistent with GDP growth and inflation objectives, and an increase in money demand reflecting the reintegration of the south. The monetary target and the projected build-up in foreign reserves should allow for an appropriate growth rate of credit to the non-governmental sector. The conduct of monetary policy will be challenging given a number of uncertainties, including the impact of the post-conflict activities (e.g., the introduction of new currency), the size of the private capital movements, oil export receipts, and aid flows. Accordingly, we expect to reassess the broad money growth target during program reviews to ensure that it remains in line with the program's inflation objectives.

22. The conduct of monetary policy will continue to rely on indirect monetary instruments and no restrictions will be imposed on market financing rates and banks' credit allocations. In addition, the lending to public enterprises (including for agriculture) will remain curtailed. However, the BOS will continue to assist in managing, but not extending, the financial support provided by the government to agriculture, given the underdevelopment of the agriculture finance infrastructure in Sudan at present. By mid-2005, we intend to rely completely on open market operations for supporting banks' liquidity needs. To support this objective, all government securities will be issued through competitive auction process. We have also closed the cost-free overdraft window for the government, and lending to the government will be carried out solely through government 
securities. Finally, direct lending to banks will be limited to support surges in seasonal credit demands.

23. We will continue to pursue our plan to restructure and strengthen the banking system. Commercial banks' minimum capital requirements will be raised from SDD 3 billion to SDD 6 billion with banks required to meet the new capital requirement by end-2008. Under performing banks will be encouraged to either merge, transform themselves into small-specialized banks, or will be close. Foreign banks are allowed to operate freely in Sudan, and a number of new foreign banks are expected to commence operations in 2005 . We plan to prepare a new financial sector reform program by end-December in light of the recommendations of the recently concluded Financial Sector Assessment Program (FSAP) and the mandates of the peace agreement.

24. We are committed to maintaining an exchange system that is free of restrictions on the making of payments and transfers for current international transactions in accordance with our acceptance of the obligations of Article VIII, sections 2, 3, and 4 of the Fund's Articles of Agreement. We understand that further evaluation from the Fund's Monetary and Financial Systems and Legal Departments is required to ascertain compliance with Article VIII obligations and we are determined to implement any actions that may be required for that purpose. We are committed to implementing a managed float exchange rate regime that prevents sharp fluctuations in the exchange rate. In 2005, the dinar may continue to face appreciation pressures in light of the projected large foreign exchange (oil and aid-related) inflows, but we may resort to monetary sterilization to prevent an excessive appreciation that could undermine the recent recovery of non-oil exports and our efforts to diversify Sudan's economy away from oil dependency.

\section{Trade and External Debt}

25. We remain committed to an open trade regime. The current liberal non-tariff trade barrier regime will be maintained. We are also planning a new three-year import tariff reform program that will further reduce tariff protection, and will bring Sudan's tariff regime in line with the schedule mandated by the Common Market for Eastern and Southern Africa (COMESA) customs union agreement. However, because of the exceptional demands of peace on fiscal resources and uncertainties about donor support, we will postpone the launching of the new tariff reform program until 2006. In this context, we also received an exemption to delay any additional tariff reductions from the COMESA obligations for 2005. We will proceed to update the tariff reform proposal prepared in 2004 and incorporate it in the 2006 budget.

26. Sudan continues to pursue actively its application for accession to the World Trade Organization (WTO). It has presented all the required documentation to the WTO working party. Sudan has also applied for exemptions from agreement on Trade-related Aspects of Intellectual Property Rights (TRIPS) and customs duties on agricultural goods and some industrial products, and asked for a transitional period to implement all obligations. 
27. Sudan's external debt is unsustainable by any standard, and most of it is in arrears. The estimated end-2003 stock of public and publicly guaranteed debt was about US\$2 5 billion, of which about US\$21 billion was in arrears. Solving the debt and arrears problems is an important goal for the Government of Sudan and we are looking forward to the Fund's early update of the 2001 Board paper on resolving Sudan's external debt problems. Without an early resolution to this problem, Sudan will be denied access to concessional development assistance at a time when it is most needed to support the peace efforts in Sudan. In 2004, we had to contract or guarantee new external financing on nonconcessional terms in order to implement critical social and development projects, such as supply of water and electricity. In 2005, we will limit the contracting or guaranteeing of nonconcessional external loan to US\$150 million only, for high priority projects, mainly in the social sector.

\section{Other reforms}

28. We are taking a number steps to encourage private sector participation in the economy. On the public enterprise front, we have adopted a reform program to privatize about 42 enterprises most of which operate on a commercial basis and do not receive budgetary support (e.g., the Sugar Trading Company, the Sudanese Company for construction, Shibak Transportation Company, Nile Cement Company), and convert other large enterprises to shareholding companies with the government's share limited to a maximum of 20 percent (e.g., Sudan Airways and the National Company for Roads and Bridges). All other economic activities are open to private sector participation; foreign investors are treated at par with local ones; an anti-trust law has been prepared and a legal review to modernize our commercial laws and legal institutions is underway.

29. With the expected rise in oil production, we are fully aware of the importance of continuously improving oil sector transparency, and we remain committed to this objective. One important milestone will be the establishment (as stipulated in the peace agreement) of a new National Petroleum Commission that will oversee all oil sector activities and report to parliament. The commission is expected to be constituted in mid-year and will begin reviewing immediately the existing oil operations and the process of managing oil revenues. The Commission is also mandated to prepare a national policy for future oil sector activities. In the meantime, the SPC will begin the process of changing its accounting standards with a view to aligning them with the applicable commercial accounting standards in Sudan.

30. As detailed below, our medium-term policies will focus on poverty alleviation and development. To this end, we are preparing an interim Poverty Eradication Strategy (PES), which is meant to provide a foundation for a full PES for the new national unity government. It stresses on relevant and flexible policies that ensure macroeconomic framework consistent with post-conflict challenges, decentralization, an enabling environment for private sector growth, and capacity and institutional building. 


\section{MEDIUM-TERM OUTLOOK AND POLICIES}

31. Our medium-term strategy is based on sustaining the high economic growth and macroeconomic stability achieved in recent years, while focusing on poverty alleviation (in the context of pursuing the Millennium Development Goals (MDGs)) and post-conflict recovery. Structural reforms that enable private-sector led growth, coupled with public investments in health and education and key infrastructure will allow growth to be sustained over a longer horizon, while a reorientation of public expenditures will allow for increased spending on poverty reducing programs. International donor assistance will be critical for the attainment of the growth and poverty reduction objectives, by supporting the balance of payments needs and higher investment levels for reconstruction, infrastructure and human capital development.

32. The medium-term macroeconomic framework envisages economic growth of about 8-9 percent and prudent macroeconomic policies that ensure single digit inflation and a steady build up in international reserves. We anticipate economic growth to be broad-based across all economic sectors to ensure economic diversity. A surge in oil production and post-conflict activities will spur growth in the next two years, while over the longer term the economy will diversify away from oil as sectoral policy reforms begin to yield results. Achieving the growth objectives would require higher domestic investment rates and greater reliance on foreign savings. Gross domestic investment is expected to rise by about 3 percentage points of GDP reflecting a substantial increase in public spending (at all levels of government), particularly on reconstruction in the south.

33. The external position is likely to worsen over the medium term. On a cash basis, the external current account deficit will rise from 4 percent of GDP in 2004 to about 6 percent in 2006 and stabilize at that level thereafter, as both oil export growth tapers off and postconflict import needs mount. We expect private inflows (transfers and FDIs) to remain strong and responsive to our policies, especially given the assumption of peace, and to continue playing an important role in funding the balance of payment. Nevertheless, a significant external gap is likely to emerge without international donor support. We are hopeful that this support will be forthcoming in the near future. However, in the unfortunate event that such support falls short of what is needed, we will tighten our policies to the extent possible and, if necessary, aim for less ambitious build up of international reserves. As a result economic growth and poverty reduction efforts will be adversely affected and the vulnerability of our external position will rise.

34. Fiscal policy will aim at maintaining low domestically financed deficit to support macroeconomic stability, mobilize new domestic resources, reorient expenditures towards infrastructure development, human capital improvement, poverty reducing programs, and support the decentralization process. The continued savings of oil revenues will ensure fiscal stability in the face of unexpected oil price shocks, and facilitate macroeconomic stability. Strengthening non-oil revenues will remain a priority and we aim to raise these revenues, at a minimum, from about 10 percent of GDP in 2004 to about 12 percent by 2010, notwithstanding the expected customs revenue loss from the planned tariff reform 
(about 1 percent of GDP). Measures will include a further reduction in exemptions, broadening of the tax base, phasing back the excise tax on petroleum products, and strengthening tax and customs administration. On the expenditure side, the focus will be on supporting demobilization and fiscal decentralization, reducing military spending subject to the Demobilization, disarmament and reintegration program (DDR), and channeling substantially higher resources to social programs (in line with the poverty alleviation goals) and development spending (particularly on much needed basic infrastructure).

35. Monetary policy will continue to target a broad money growth rate consistent with the inflation and economic growth objectives. The existing monetary regime, in close coordination with fiscal policy, should be adequate to support the achievement of macroeconomic objectives while responding to the challenges of monetary policy in coming years. These challenges include potentially large private capital movements, oil export receipts, aid flows, and unforeseen fiscal shocks (at the federal and state levels).

36. We believe that a managed-float exchange rate regime remains appropriate for Sudan over the medium-term, although we foresee a steady move towards an independent floating regime as conditions improve in the foreign exchange market. The maintenance of the current system is justified because of the lumpy nature of key foreign exchange flows (aid flows, and FDIs), and the underdevelopment of foreign exchange markets and instruments. Still, we will ensure that the exchange rate remains responsive to underlying fundamentals to avoid exchange rate misalignments.

37. We would like to express our appreciation for the technical assistance extended by the Fund to Sudan in different fields, and we hope for a continuation of this valuable and indispensable assistance, particularly in support of the post conflict needs. In the central banking area, technical assistance is needed for the introduction of new currency, central banking restructuring and bank regulations to accommodate the dual banking system, monetary operations, and payment systems. As for the fiscal area, we are in need for technical assistance in development of a public expenditure management strategy, budget accounting and classification, fiscal decentralization, government securities, tax policy, tax and customs administration, and modernization of treasury. In addition, the statistical macroeconomic database needs to be improved and technical assistance in the areas of fiscal statistics, balance of payments; management of monetary data for banking supervision, and national accounts is needed to improve further the macroeconomic database.

\section{RELATIONS WITH THE FUND AND OTHER CREDITORS}

38. We remain committed to regularizing relations with all our creditors and, in particular, strengthening Sudan's relations with the Fund. In addition to strong cooperation with the Fund on economic policy matters, including through satisfactory performance on SMPs since 1997, Sudan made regular payments to the Fund as committed under the 2004 SMP (\$30 million), and paid a total of \$366 million since the first SMP in 1997, reducing 
our arrears by about 120 million SDRs. We hope that our record of cooperation will be fully recognized, particularly when moving forward with arrears clearance.

39. In 2005, Sudan's debt service capacity will be constrained by the considerable burden of post-conflict needs and emergency imports for Darfur. Any shortfall (or even a delay) in donor assistance or a negative shock in oil prices would further limit our capacity to service its debt obligations. As continued proof of our commitment to normalize our relations with the Fund and notwithstanding the demands of peace and imports for Darfur emergency, we would like to maintain the level of payments to the Fund at US\$30 million in 2005 .

40. We are making good progress in regularizing relations with external creditors but clearance of large arrears remains a daunting challenge. Partial debt service payments are being made to almost all of the multilateral creditors. Sudan is also servicing its obligations to a number of bilateral Arab funds, which in most cases are providing net financing inflows for various social sector projects. Finally, we will work closely with the creditor support group led by the United Kingdom to secure the support of donors for resolving our external debt problem under the Heavily Indebted Poor Countries (HIPC) initiative.

\section{Program Monitoring}

The proposed semi-annual quantitative targets for the periods up to end-June and endDecember 2005 are set forth in Table 1, and the structural benchmarks are detailed in Table 2. The quantitative targets focus on ceilings on the change in net domestic assets of the BOS and the domestic financing of the fiscal deficit; floors for the buildup of international reserves; and ceilings on new nonconcessional external debt. There is an oil revenue adjustor to be applied to the targets on international reserves, net domestic assets of the BOS, and the domestic financing of the government based on any difference between the projected change in the balance of the oil savings account and the actual change. We will closely monitor financial and economic developments in coming months and will implement any measures that may be needed to safeguard macroeconomic stability in consultation with the Fund staff. 
Table 1. Sudan: Quantitative Indicative Targets for 2005 Staff-Monitored Program

(In billions of Sudanese dinars; unless otherwise indicated)

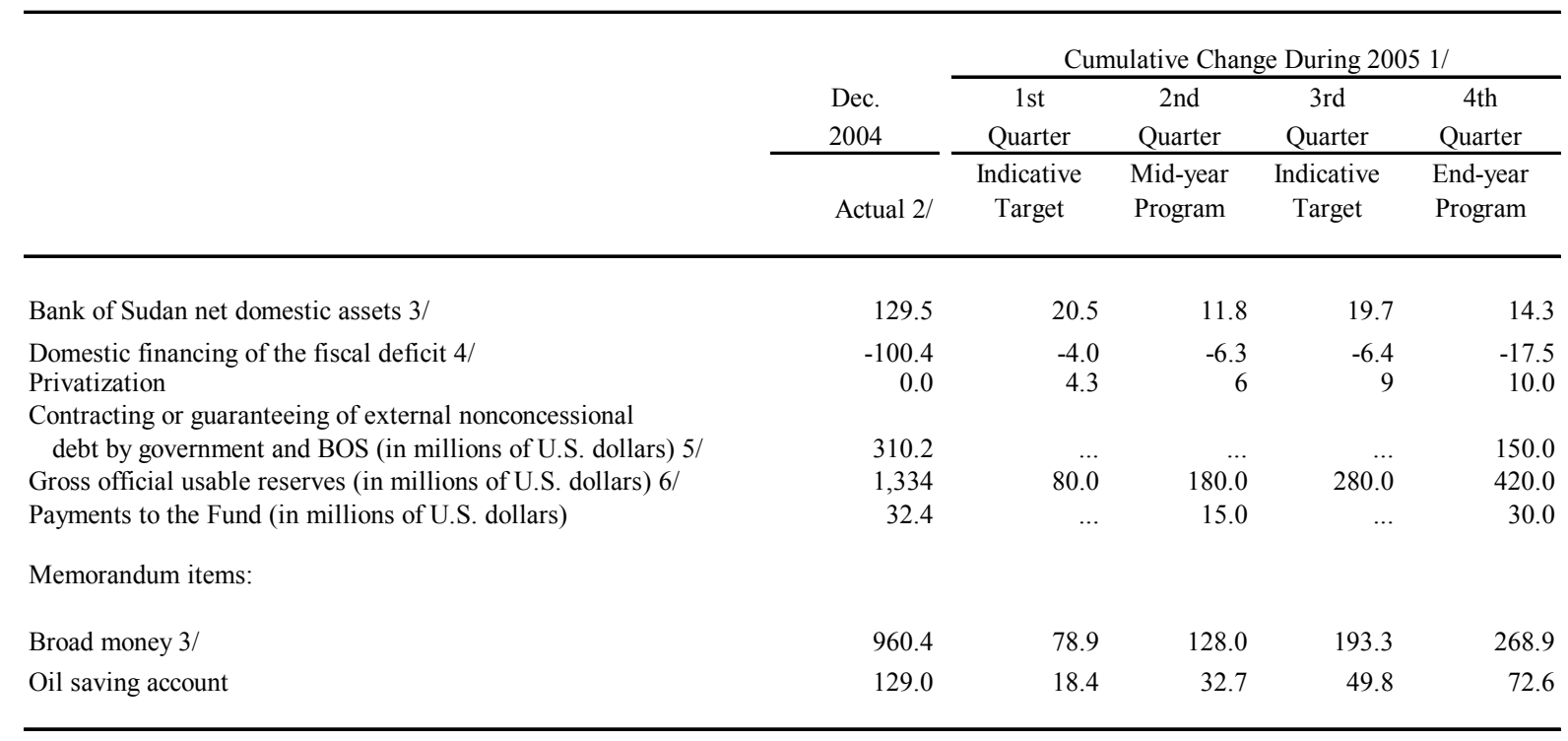

$1 /$ Cumulative change from end of the previous year.

2/ Outstanding stock at end-of year.

3/ Net BOS financing is defined as borrowing by the central bank from the BOS (including GMCs) minus central government deposits at the BOS (excluding deposits accumulation in the OSA).

4/ Defined as total net borrowing by the government, including net borrowing from the Bank of Sudan (including GMCs and changes in deposits of the central government with the BOS but excluding the OSA), net sales of GMCs outside the BOS, revenues from privatization, and repayments of internal domestic debts.

5/ This indicative target applies not only to debt as defined in point No. 9 of the Guidelines on Performance Criteria with Respect to Foreign Debt (Decision No. 12274 - (00/85), August 24, 2000), but also to commitments contracted or guaranteed for which value has not been received. Debt will be deemed to be concessional when the currency-specific discount rate (determined by the market-related "commercial interest reference rates (CIRR)" as published by the OECD) applied to the contractual schedule of charges and principal payments, indicates a grant element of at least 35 percent. The indicative target excludes the financing of the Merowe hydropower project.

6/ Include foreign banknotes in the vaults of the BOS.

7/ Central government expenditure on medical care; health services; poor students' support; supplement to poor consumers of electricity; social and health insurance; water, health, and education development. 
Table 2. Sudan: Structural Benchmarks for 2005

Prior Actions

1. Begin pilot implementation of GFS budget classification in two states and two federal ministries.

By end-June 2005

2. Introduce an auction system with competitive selling price for the General Musharaka Certificates (GMC) and General Investment Certificates (GIC) securities in the primary market.

3. Set up and operationalize a single treasury account for all Ministry of Finance's operations.

4. Establish a Medium Taxpayer Unit.

5. Develop a program (including timetable) for aligning the SPC and its subsidiaries' accounting systems with commercial standards by end 2006 .

By end-December 2005

6. Formulate the 2006 budget based on GFS classification.

7. Prepare a three-year import tariff reform program and incorporate it in the 2006 budget.

8. Establish a new financing window that allows liquidity constrained banks to sell securities to the central bank at a penalty rate.

9. Prepare a financial sector reform program in light of FSAP recommendations. 


\section{SUDAN \\ TECHNICAL MEMORANDUM OF UNDERSTANDING}

1. This memorandum specifies the understanding reached with the Fund staff regarding the quantitative benchmarks and indicative targets for the 2005 Staff-Monitored Program (SMP).

2. The 2005 SMP relies on five quantitative indicative targets for the first and the third quarters of the year and an equal number of quantitative semi-annual benchmarks. The indicative targets and the quantitative benchmarks are subject to an oil revenue adjustor. The quantitative targets are (i) ceilings on the change in net domestic assets of the Bank of Sudan (BOS); (ii) ceilings on the domestic financing of the fiscal deficit; (iii) floors for the buildup of gross usable reserves of the central bank; (iv) ceilings on new nonconcessional external loans contracted or guaranteed by the government or the central bank; and (v) floors for payments to the Fund. Broad money and oil revenues will be monitored as memorandum items. All the targets and benchmarks are presented in Attachment I, Table 1.

3. The relevant definitions for the quantitative indicative targets and the oil revenue adjustor are set out hereafter.

4. Net domestic assets (NDA) of the BOS are defined as the sum of the Net Domestic Credit of the BOS, the net issue of money market instruments and other items net (OIN) of the BOS. The Net Domestic Credit of the BOS is defined as total credit to the central government (including government musharaka certificates (GMCs) and government investment certificates (GICs)) minus total central government deposits with the BOS plus BOS claims on public enterprises plus BOS claims on banks. The definition of the central government comprises all accounts of the line ministries and agencies controlled by them (corresponding to Group no. 11, Group no. 12, and some accounts of the Group no. 19 in the BOS general ledger), the Zakat funds (recorded under Group no. 13), and margin deposits placed with BOS by the central government against letters of credit issued by the BOS. The definition includes all oil-related accounts controlled by the government. The identification of all accounting balances recorded under OIN has been established with the help of the IMF's Statistics Department mission in May 2000 and is detailed in the corresponding report.

5. Domestic financing of the fiscal deficit is defined as total net domestic borrowing by the central government, including net borrowing from the banking system (including GMCs and GICs), net sales of GMCs and GICs outside the banking system; revenues from privatization; and repayments by the central government of internal domestic debts to public agencies, banks, and private companies. The definition of central government for the purpose of this criterion is the same as the one applied for the NDA of the BOS.

6. Gross usable official reserves are foreign reserve assets (as defined in the balance of payments manual), that are controlled by the BOS and are immediately and unconditionally 
available for meeting balance-of-payment needs. They consist of balances on accounts maintained with overseas correspondent banks and foreign exchange banknotes in the vaults of the BOS.

7. Contracting or guaranteeing of new non-concessional external debt by the government or the BOS applies not only to debt as defined in point no. 9 of the Guidelines on Performance Criteria with Respect to Foreign Debt (Decision no. 12274-(00/85), August 24, 2000), but also to commitments contracted or guaranteed, for which value has not been received. Debt will be deemed to be concessional when the currency-specific discount rate applied to the contractual schedule of charges and principal payments, indicates a grant element of at least 35 percent. $^{32}$

8. Broad money is defined as the sum of local currency circulating outside of the banks, banks' demand, and time and savings deposits. It also includes transferable deposits and margin deposits against letters of credit placed by the local government, nonfinancial public enterprises, and the nonbank private sector with the BOS.

9. The oil revenue adjustor will be applied as follows: oil revenue arising from an export price of over $\$ 30$ per barrel for crude oil exports, f.o.b. Port Sudan, will be deposited in a government account at the BOS. However, amounts will be transferred, if necessary, to the government, at least on a quarterly basis, to ensure that government oil export receipts match the amounts targeted under the program. The program targets for domestic financing of the budget deficit and for changes in the NDA of the central bank will be reduced, and the international reserve target will be raised by the difference between programmed and actual revenues accumulated in the oil savings account. In the event of oil revenue shortfalls below the program targets, the accumulated balance at the BOS can be drawn down to make up the shortfall in revenue; correspondingly, the program targets for domestic financing of the budget deficit and NDA will be raised, and the international reserve target reduced.

\footnotetext{
${ }^{32}$ For program purposes, a loan is considered concessional if the grant element is at least 35 percent calculated using a discount factor based on the Commercial Interest Reference Rates (CIRRs) published by the OECD plus margins depending on the loan maturity. The margins are 0.75 percent for repayment periods of less than 15 years, 1 percent for $15-19$ years, 1.15 percent for 20-29 years, and 1.25 percent for 30 years or more. The average of the CIRRs over the last ten years will be used for loans with a maturity of at least 15 years and the average of the CIRRs for the preceding six months will be used for shorter maturities.
} 


\section{INTERNATIONAL MONETARY FUND}

Public Information Notice

EXTERNAL

RELATIONS

DEPARTMENT
Public Information Notice (PIN) No. 05/67 FOR IMMEDIATE RELEASE

May 25, 2005
International Monetary Fund

$70019^{\text {th }}$ Street, NW

Washington, D. C. 20431 USA

\section{IMF Executive Board Concludes 2005 Article IV Consultation with Sudan}

On April 29, 2005, the Executive Board of the International Monetary Fund (IMF) concluded the Article IV consultation with Sudan. ${ }^{1}$

\section{Background}

After more than two decades of civil conflict between the north and south of Sudan, a comprehensive peace agreement was concluded and signed between the Government of Sudan (GOS) and the Sudan People's Liberation Movement (SPLM) on January 9, 2005. The peace agreement stipulates the creation of a federal system and the sharing of power and resources between the North and southern Sudan.

The Sudanese economy continued to grow in 2004. Real GDP growth is estimated to increase from 6 percent in 2003 to 7.3 percent in 2004 owing to a strong performance in the oil, manufacturing construction, power, and services sectors. Improvement in productive capacity led to a 21 percent expansion in oil sector's GDP. Inflation rose to 8.4 percent in 2004 compared to 6.5 percent in 2003 reflecting loosening of monetary policy in the first half of 2004. The external current account deficit declined to an estimated 4.1 percent of GDP in 2004 from 5 percent in 2003, reflecting a surge in oil export receipts as well as strong recovery of non-oil export. Further, FDIs and private transfers rose to $\$ 2.5$ billion-more than one third higher than in 2003. Gross official reserves reached 2.9 months of imports at end-2004

\footnotetext{
${ }^{1}$ Under Article IV of the IMF's Articles of Agreement, the IMF holds bilateral discussions with members, usually every year. A staff team visits the country, collects economic and financial information, and discusses with officials the country's economic developments and policies. On return to headquarters, the staff prepares a report, which forms the basis for discussion by the Executive Board. At the conclusion of the discussion, the Managing Director, as Chairman of the Board, summarizes the views of Executive Directors, and this summary is transmitted to the country's authorities.
}

Washington, D.C. 20431 • Telephone 202-623-7100 • Fax 202-623-6772 • www.imf.org 
compared with 1.5 months at end-2003. The dinar appreciated by about 3 percent vis-à-vis the U.S. dollar and by about 8 percent in real effective terms.

Higher oil and non-oil revenues have turned the overall fiscal balance into a surplus in 2003 and 2004, despite higher spending. Total fiscal revenues reached 21.5 percent of GDP in 2004 compared to 16.8 percent of GDP in 2003. Non-oil revenues rose from 8 percent of GDP in 2003 to 10.4 percent in 2004, largely because of improved efficiency from the new large taxpayer unit, a reduction on exemptions, and a telecom license fee. Oil revenues continued to increase in 2004 mainly because of higher production and prices, which allowed1.6 percent of GDP accumulation in the oil savings account. Expenditures also rose because of unanticipated emergency spending and capital outlays.

Broad money growth decelerated in December 2004 to 30.8 percent (after accelerating at an annual rate of 37 percent in the first half of 2004), compared to 30.3 percent (on annual basis) at 2003. In an attempt to contain the excessive growth of broad money, the central bank took steps to mop up liquidity in late 2004.

Sudan embarked on a number of policy and institutional reforms in recent years aimed at sustaining economic growth, maintaining macroeconomic stability, and meeting the challenges of the peace agreement with the south. On the fiscal front, a review of exemptions-granting regulations and agreements was completed and an action plan to streamline such regulations is being developed. Regarding monetary and financial sector reforms, the central bank has improved the management and monitoring of liquidity and the increase in minimum capital requirements for banks has been effected. A tariff reform program has been developed but its implementation has been delayed to 2006 because of the fiscal needs arising from the peace agreement. Oil sector transparency has improved; the Auditor General office has audited the accounts of the Sudan Petroleum Corporation and submitted his report to Parliament.

\section{Executive Board Assessment}

Executive Directors commended the Sudanese authorities for persevering with prudent fiscal and monetary policies and wide-ranging structural reforms in a difficult environment. These policies have translated into a favorable economic performance, marked by a pickup in foreign investment, a strengthening of the external position, and single-digit inflation. While oil production increased sharply, growth of the non-oil sector has also been strong-evidencing progress in diversifying the economy.

Directors welcomed the recent comprehensive peace agreement in south Sudan, and were encouraged by the positive response from the donor community for Sudan's reconstruction and development. At the same time, Directors recognized the serious challenges ahead in ensuring the successful implementation of the peace agreement, and, in particular, in resolving the conflict and humanitarian crisis in Darfur. They stressed that decisive action in these areas will be key to allowing Sudan to realize its full economic potential, move towards normalizing its relations with creditors, and make progress toward reaching the Millennium Development Goals. 
Directors welcomed the satisfactory implementation of the staff-monitored program in 2004 and the policy package embedded in the program for 2005. They noted that the implementation of the peace agreement will require strong efforts in institution building, and that its cost could put pressure on the 2005 economic program, while uncertainties also remain related to oil prices and the amount of donor support. In this regard, Directors recognized that the economic program and the budget for 2005 will likely need to be revised to take into account recent developments.

Most Directors supported the view that the policy commitments under the staff-monitored program for 2005 continue to be in line with what would be required for a Rights Accumulation Program (RAP). In this view, Sudan's performance under the successive Staff Monitored Programs since 2002 should be reflected in the timetable for arrears clearance, when financing assurances from Sudan's creditors become available. A number of Directors suggested that the RAP could be waived at that time. In the meantime, staff engagement will continue, including by stepping up Fund technical assistance in core areas that will be critical for the effective implementation of the peace accord.

Directors commended the authorities' prudent fiscal policy in the last few years, which has been supported by tax reforms and the saving of oil revenues in the Oil Savings Account (OSA). They welcomed the cautious approach set out in the 2005 budget, including the postponement of the increase in civil service wages. Directors noted that the authorities' decision to strengthen fiscal federalism by accelerating decentralization calls for the urgent strengthening of state and local government capacity. Given the need to protect social and infrastructure spending, Directors urged continued efforts at strengthening public expenditure management and restraining non-priority spending. On the revenue side, further efforts to boost non-oil receipts by broadening the tax base and improving tax collection will continue to be a priority. Some Directors suggested preparing contingency measures in the event that oil prices and donor support are lower than envisaged.

Regarding oil revenues, Directors called for increased transparency in oil sector operations. Some Directors suggested that transparency would be enhanced through Sudan's participation in the Extractive Industries Transparency Initiative.

Directors commended Sudan's continued prudent monetary policy. In light of emerging fiscal and monetary pressures, they urged the authorities to remain vigilant and tighten monetary conditions if inflationary risks emerge. They noted the importance of a closer coordination between the central bank and the fiscal authorities (including at the state level) as well as the need for establishing market-oriented operations in government securities.

Directors welcomed the recent measures to increase exchange rate flexibility and considered the managed float exchange rate regime appropriate at the current stage of Sudan's development. Following the delay in launching the three-year tariff reform program, it will be important to incorporate these reforms in the 2006 budget to help reduce distortions, increase competitiveness, and send a strong signal to investors about Sudan's commitment to an open trade regime. 
Directors agreed with the conclusions of Sudan's Financial Sector Stability Assessment. They welcomed the steps already taken to improve the banking system, and encouraged the authorities to press ahead with the implementation of the Financial Sector Assessment Program recommendations. Priorities should be to improve the ratios on nonperforming loans and capital adequacy, and to press ahead with the privatization of public banks and the financial sector reforms associated with the implementation of the peace agreement. Directors welcomed the recent legislation on anti-money laundering and combating the financing of terrorism, while encouraging further efforts to address any remaining weaknesses in the legal framework.

Directors expressed concern about the contracting of nonconcessional debt in 2004. They stressed that even though Sudan's needs are high, the authorities should minimize nonconcessional borrowing to avoid aggravating the external debt overhang and complicating debt rescheduling negotiations. Directors expressed the strong hope that the implementation of the planned improvements in the authorities' debt management strategy will effectively deal with this problem. They also stressed the importance of a comparable treatment of all bilateral creditors.

Directors welcomed the progress made in improving economic data, as well as Sudan's participation in the General Data Dissemination System. They underscored the importance of moving ahead with the adoption of Government Finance Statistics methodology and of improving the quality of balance of payments and national accounts data.

Directors noted that the regularization of Sudan's relations with creditors remains a critical challenge given the country's large stock of external debt and arrears, and will require comprehensive efforts from all creditors. To help guide future discussions, Directors felt that it would be useful to fully update the paper presented in 2002 on the Fundamental Issues in Resolving Sudan's Debt and Arrears. In this connection, while some Directors noted that it could be premature to enter into detailed discussions of an arrears clearance strategy at this time, some other Directors called for early concrete steps toward addressing these issues. More generally, many Directors stressed that progress in resolving Sudan's debt and arrears problems requires a satisfactory solution of the Darfur crisis and implementation of the peace agreement. With respect to the level of payments to the Fund, some Directors encouraged the authorities to consider increasing payments in 2006 in line with Sudan's improved debt servicing capacity. However, other Directors felt that the current level of payments remains broadly appropriate, given the substantial demands of implementing the peace process, including the large social and infrastructure needs.

Public Information Notices (PINs) form part of the IMF's efforts to promote transparency of the IMF's views and analysis of economic developments and policies. With the consent of the country (or countries) concerned, PINs are issued after Executive Board discussions of Article IV consultations with member countries, of its surveillance of developments at the regional level, of post-program monitoring, and of ex post assessments of member countries with longer-term program engagements. PINs are also issued after Executive Board discussions of general policy matters, unless otherwise decided by the Executive Board in a particular case. 
Sudan: Selected Economic and Financial Indicators, 2000-04

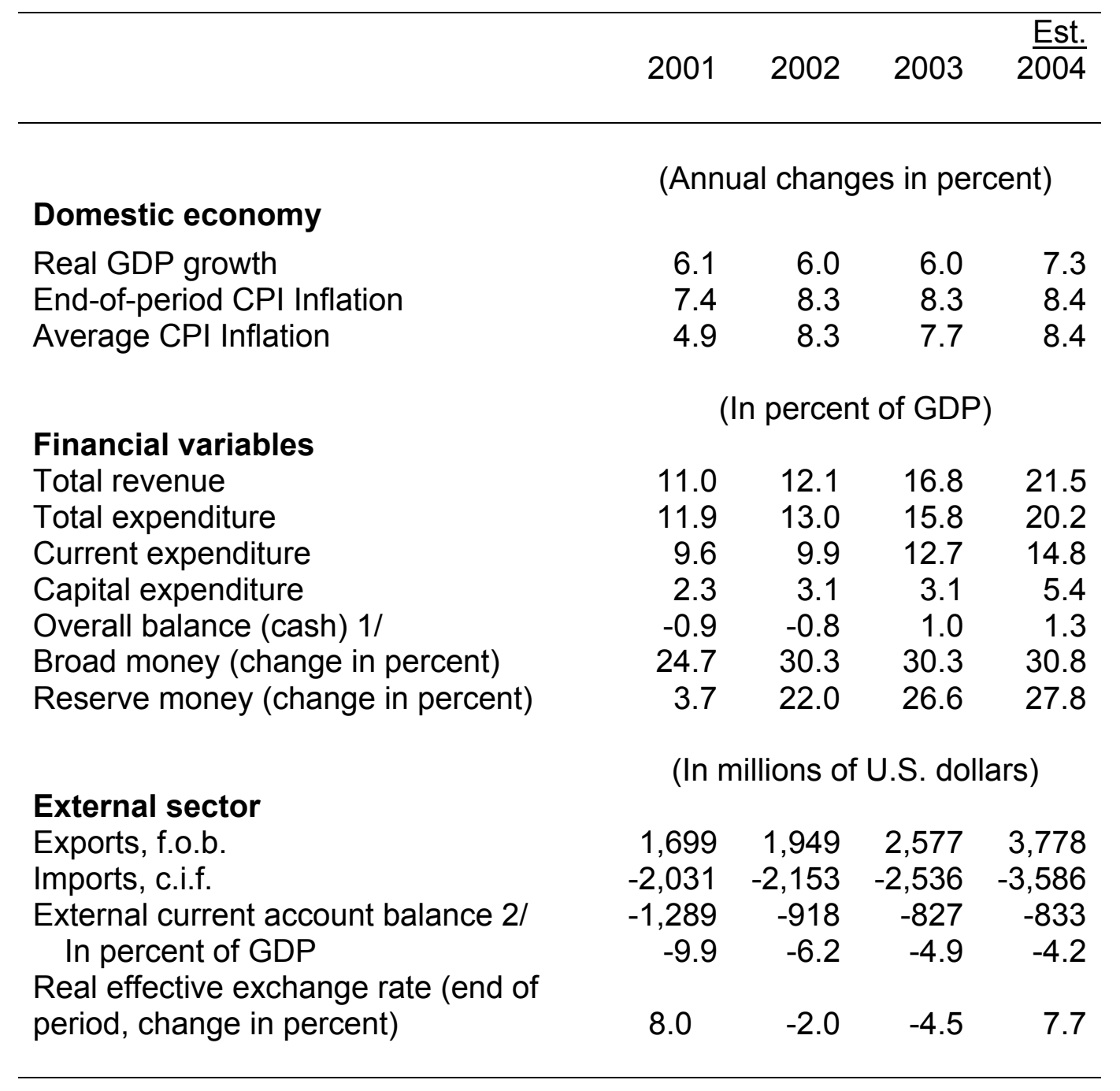

Sources: Data provided by the Sudanese authorities, IMF staff estimates. $1 /$ Including accumulation in the oil savings account (OSA).

2/ On a cash basis, excluding public interest due and public transfers. 


\section{Statement by Peter Ngumbullu, Executive Director for Sudan and John Mafararikwa Senior Advisor to Executive Director April 29, 2005}

Key points

- The Sudanese signed a comprehensive peace agreement in early January 2005 and negotiations are underway to resolve the disturbances in Darfur.

- The authorities are calling for the removal of the remaining sanctions on Sudan to allow the country a fast take-off.

- Permanent peace and the ongoing broad based high economic growth will help Sudan reach the MDGs and reduce poverty if adequate external assistance, including debt relief is delivered in a timely manner.

- The authorities are grateful for the generous donor pledges made in Oslo and urge for timely disbursement of these resources.

- Performance under the 2004 SMP and the program for 2005 meet the strength of a RAP and performance since 2002 has been of similar strength.

- Payments to the Fund have exceeded those needed to stabilize arrears.

- To meet immediate demands arising from the peace agreement, the humanitarian situation in Darfur and drought relief, wage increases and other important outlays have been postponed and payments to the Fund will remain at their level of 2004.

- Due to lack of access to development financing, Sudan has been forced to contact nonconcessional loans to finance growth enhancing investments.

- Sudan's debt is unsustainable. The net present value of debt is 850 percent of exports, far exceeding the 150 percent under the HIPC Initiative.

- Sudan has met all the conditions (policies and payments) of a RAP since 2002. The Fund should now move speedily to facilitate the clearance of Sudan's arrears and allow the country to forgo RAP and move directly to PRGF and HIPC.

- Debt relief and access to humanitarian and development assistance is critical to sustain peace in Sudan.

\section{Introduction}

On January 9, 2005 the Sudanese signed a comprehensive peace agreement, bringing finality to a prolonged civil conflict, in which more than a million human beings perished and several millions others were displaced. The authorities are engaged in negotiations to bring lasting peace to Darfur and the rest of the country. This removes a major obstacle for socioeconomic development and effective utilization of aid. With permanent peace, Sudan now has all the basic ingredients that enhance its potential and chance to reach the MDGs, including a diverse resource base and a committed leadership with solid track record of pursuing and implementing prudent macroeconomic and structural policies. In fact, the medium-term outlook envisages real GDP growth rates of 8-9 percent, exceeding the minimum rate for reaching the MDGs. Already between 2001-2004 real GDP growth rate averaged 6.4 percent and is expected to accelerate to 8.3 percent in 2005 . 
These positive developments should now be followed and complemented by fast delivery of technical assistance for human and institutional capacity building in the new environment and adequate and timely development and humanitarian assistance. This will help cement peace while fast tracking the country towards poverty reduction and reaching the MDGs. In this regard, the recent donor conference in Oslo, Norway, was timely and the authorities thank development partners for their generous pledges while urging them for timely disbursement. The authorities are also requesting those countries that still maintain sanctions against Sudan to remove them and assist the authorities the country make progress in dealing with the current challenges.

The Fund has a critical role to play in unlocking development assistance and facilitating debt relief. The authorities have been implementing RAP equivalent policies and payments under successive Staff Monitored Programs (SMP) since 2002. With this solid performance and the peace agreement, the authorities are requesting the Fund to facilitate clearing arrears immediately and allow Sudan to forgo the Rights Accumulation Program (RAP) and move speedily to a PRGF and HIPC Initiative simultaneously.

\section{Performance in 2004 and the 2005 SMP}

Performance under the 2004 SMP was broadly in line with the program. All quantitative benchmarks were met with the exception of the contraction of non-concessional loans, which was necessitated by lack of access to financing at appropriate terms and the need to finance immediate needs of the economy. Structural benchmarks were broadly implemented and some were post-poned to take into account the peace agreement and to provide room for adequate preparation. Both the performance during 2004 and commitments under the 2005 SMP are equivalent in strength to that required under a RAP.

\section{Output Growth}

Real GDP growth accelerated to 7.3 percent in 2004, reflecting the continued implementation of strong policies. While oil output surged, growth remains broad based, with strong performance of agriculture manufacturing, construction, power and services sectors. This diversification of growth provides assurances that monetary, structural and exchange rate policies have been appropriately managed to avoid a Dutch Disease following the discovery of oil. Real GDP growth is projected to accelerate to 8.3 percent in 2005 . The major sources of growth are the significant increase in oil production and private and public investment in infrastructure. Nevertheless, non-oil GDP will be adversely affected by reduced crop production due to weak rainfall in many parts of the country.

\section{Fiscal Performance}

The humanitarian and security situation in Darfur prompted the authorities to increase expenditure through a supplementary budget. Also, reflecting the ongoing return of economic activities to most parts of the country, capital outlays increased from 3.1 percent of GDP in 2003 to 5.4 percent in 2004. As a result, total expenditures increased from 15.8 percent of GDP in 2003 to 20.2 percent in 2004 . The authorities stepped up their effort to mobilize 
domestic resources. The establishment of a large taxpayers' unit improved efficiency in revenue mobilization, while the reduction in exemptions and a new telecom license fee broadened the tax base. As a result non-oil revenue increased from 8 percent of GDP in 2003 to 10 percent in 2004, exceeding the program target of 9 percent. The oil stabilization account continues to serve the country well. Given the increased oil prices, the authorities also increased their contributions to the oil stabilization account above the program target. The overall fiscal balance recorded a surplus of 1.3 percent of GDP compared to a deficit of 1.2 percent under the program, obviating the need for new net domestic financing.

In 2005 the country is facing a number of expenditure pressures. To accommodate the peace process, transfers to the South are increasing as well decentralization-related transfers to other states. Given the tight domestic resource envelope, a planned civil service wage increase and allocations to social sectors, infrastructure and general reserves have had to be postponed until additional financing is identified. On the revenue side, in view of the increase in international oil prices, which will also increase revenue, the OSA benchmark price was raised to accommodate pressing needs. Further increase in revenue will rely more on structural measures to broaden the base and improve efficiency. In the sprit of nursing the nascent political stability and consolidating implementation of the peace agreement, raising taxes has not been considered as an option in 2005, and for the same reasons, the excise tax on domestic petroleum products was reduced to mitigate the social impact of the ongoing increase in oil prices. In anticipation of a clearer picture emerging from the ongoing formation of a National Government, demand on transfers to cope with the return of displaced persons, progress in Darfur, the extend of donor support, among others, it is anticipated that a supplementary budget would be appropriate around the middle of the year to accommodate unfunded expenditure needs while identifying additional financing.

\section{Monetary policy}

High FDI inflows and oil export revenues posed challenges for liquidity management during the first half of 2004. however, in the second half of the year, monetary conditions were tightened through open market operations, foreign exchange sales, increase in reserve requirements and calling back of loans extended to banks. Consequently broad money growth decelerated and inflation was contained at 8.4 percent, slightly above the 7.7 percent of 2003. Banking system indicators improved, with the ratio of nonperforming loans falling and profitability and capital adequacy ratio increasing.

In 2005, average inflation is projected to be contained at 7.5 percent. The authorities are gearing for potential monetary shocks emanating from the introduction of a new currency, aid flows, oil export receipts, large capital inflows and a structural increase in the demand for money associated with the reintegration of the South. These developments will require active monitoring by the BOS and closer coordination with the central government and the government of the South. The authorities will review the situation in mid-year and will need technical assistance to cope with these challenges. 


\section{External sector}

Oil exports grew by 50 percent and non-oil grew by a strong 37 percent. The country also benefited from higher transfers from abroad and FDI inflows. As a result, the current account deficit declined to 4.1 percent of GDP and foreign exchange reserves increased from 1.5 months of imports at end-2003 to 2.9 months at end-2004. Measures were taken to enhance exchange rate flexibility; the band for daily exchange rate fluctuations was widened to \pm 3 percent while some restrictions on the amount of foreign exchange traded were removed. Although the local currency appreciated somehow against the US\$, this did not jeopardize competitiveness, given that it was underpinned by strong fundamentals and prudent monetary and exchange rate policies. The export sector therefore remains vibrant and competitive, as reflected by high growth of non-oil exports.

Oil and non-oil exports, especially cotton and meat, are projected to grow rapidly in 2005. However, imports are expected to grow faster, led by post-conflict related needs as well as investment related imports. Notwithstanding the continued capital inflows, and projected humanitarian aid and project financing, the outlook is clouded with potential exogenous shocks emanating from uncertainties in oil prices, the extend of peace related needs, the vagaries of the weather and the timing of aid delivery. In this context, the authorities are prepared to take contingency measures and will continue increasing international reserves.

\section{Structural Reforms}

The authorities enhanced their agenda for structural reforms. A comprehensive review of tax exemptions was completed and this will be followed by a streamlining of the tax incentives regime. Tax privileges of four major oil distribution companies lapsed at end-2004 and will not be renewed. A medium-term tariff reform program was developed and the timing of implementation will take into account the revenue consequences in the face of huge resource demands from the peace agreement. Oil sector transparency was further improved; and, the Sudan Petroleum Corporation (SPC) was audited and the audits of the subsidiaries are in progress. Preparations are underway to align SPC accounts with the country's commercial accounting standards.

Structural reforms will be deepened in 2005. In the fiscal area, the autonomy of the cash management system will be enhanced, and a single treasury account for the ministry of finance will be set-up while those for the rest of the ministries will be done in 2006. Work on the GSF classification methodology in the budgetary accounts will be accelerated in 2005 and completed by 2006. The South is taking-off with the GFS classification. The tax base will be further broadened by setting up of a medium-size taxpayers' unit while transparency in the oil sector will be further improved. In the monetary area, capacity will be strengthened in managing monetary operations, especially effective short-term liquidity forecasting and coordination with fiscal operations. The authorities are broadly in agreement with the FSAP recommendations and intend to formulate an action plan to implement them. External sector reforms will continue, including further tariff reform that will take into account the need to minimize revenue losses, fulfilling commitments under AFTA and COMESA and advancing 
preparations to join the WTO. The authorities are urging for the removal of trade sanctions to improve effectiveness in their operations and policies.

\section{Payments to the Fund}

Sudan has maintained a good record of payments to the Fund. In 2004, US\$32.4 million was paid to the Fund, compared to US\$30 million envisaged under the program. These payments were US\$12.5 more than what is needed to stabilize arrears to the Fund. While oil receipts increased in 2005, peace and other demands have added pressure on the domestic resource envelope, arising from the substantial and immediate budgetary pressures from the peace agreement with the south, expenditure increase in the Darfur for enforcing peace and humanitarian assistance, relief to a number of areas that have been hit by drought, and more resources are needed to deepen the ongoing nationwide decentralization process, especially in light of the peace agreement, and uncertainties remaining about future oil receipts and the extend of donor support. The authorities therefore intend to maintain payments to the Fund in 2005 at the level of 2004.

\section{Need for External Assistance}

Sudan has implemented difficult reforms without external financial support. This situation has forced the authorities to contract some non-concessional loans for critical investments in the oil sector, electricity generation and water supply, which has contributed to boosting economic growth. To avoid compounding the debt problem and debt relief negotiations, the authorities are requesting for faster progress towards clearing arrears, debt relief and access to concessional financing. In making payments to creditors, the authorities have been giving preference to the Fund, other multilaterals and creditors that are providing new financing.

The Joint Assessment Mission, comprising the Bank, UN, Donors, the Fund and the authorities (North and South) estimated Sudan's post-conflict needs for the first phase of the peace agreement (2005-2007) at US\$7.9 billion. Of this amount, US\$5.3 billion will come from domestic sources leaving a financing gap of US\$2.6 billion. To fill this gap, donors pledged a total of US\$4.5 billion in Oslo, Norway on April 11-12, 2005. Of this amount, US\$1.9 billion is for development assistance and US\$2.6 billion is for direct delivery for humanitarian support. The World Bank has established two trust accounts to help manage and disburse external assistance. The authorities are grateful to the donors for their generous pledges and they will make an effort to address some of the concerns expressed by donors to secure disbursement. However, streamlining of donor conditionality is needed for the timely delivery of these resources which are critical to sustain peace and economic development.

\section{External Debt Burden and Arrears Clearance}

Sudan's external debt is unsustainable. Total outstanding debt exceed US\$25 billion, most of which is in arrears. The net present value of debt is estimated at US $\$ 24$ billion, about 850 percent of exports of goods and services, far exceeding the 150 percent threshold under the HIPC Initiative. Oil output's contribution to growth is expected to peak in 2006 but to subsequently decline thereafter. To alleviate the debt burden and allow Sudan to consolidate 
peace and development, the Fund should move expeditiously to facilitate the clearance of Sudan's arrears, paving the way for more comprehensive and deeper debt relief. Given Sudan's strong track record of policies and payments, and the urgency for debt relief, there is a valid case for Sudan to skip the RAP altogether, and move directly to the PRGF and bring forward the decision point under the HIPC initiative. The Paris Club should also be advancing the discussion of modalities for providing debt relief to Sudan and such discussions should invite and incorporate non-Paris Club creditors with substantial exposure to Sudan. In the case of Sudan, deep and faster debt relief is possible only if all creditors move to provide debt relief in tandem and at comparable terms. The BWI staffs and donors should also help provide technical assistance to strengthen local capacity to speed-up debt relief negotiations.

\section{Technical Assistance Needs}

The authorities are grateful for the extensive technical assistance provided by the Fund since Sudan began implementing SMPs. This has helped to build institutions, enhanced capacity for macroeconomic management, and strengthened the coverage, timeliness and quality of the statistical database, among other benefits. The signing of the peace agreement and the resumption of economic activities country-wide, especially the reintegration of the South will pose new challenges to existing institutions, and will stretch the existing limited administrative capacity and will require the building of new institutions as well as extensive training of locals. In this regard, the authorities are requesting technical assistance in the areas of revenue administration, fiscal federalism, strengthening government financial management, GFS classification, introduction of the new currency, liquidity forecasting, etc. The authorities presented their full list of TA needs and training requirements to the relevant departments within the Fund during the Spring meetings and hope that their request will be accorded high priority given their good track record of implementing TA recommendations.

\section{Conclusion}

The Sudanese authorities intend to cease the opportunity provided by the comprehensive peace agreement with the South to bring peace to the whole country and embark on an ambitious economic and social development agenda that will lead the country towards the MDGs, while maintaining macroeconomic stability. This objective can only be met within the context of an enabling external environment and with adequate technical and financial support from the international community. Sudan has established a long and solid track record of policy implementation and deserves to be fast-tracked in clearing arrears, qualification for PRGF and access for debt relief under the HIPC initiative. The Oslo donor conference set the appropriate pace and scope for external assistance and the authorities urge the Fund to fully restore its relations with Sudan, assume its catalytic role for international support and provide technical assistance. Removal of sanctions and provision of market access will allow Sudan to accelerate economic development. 